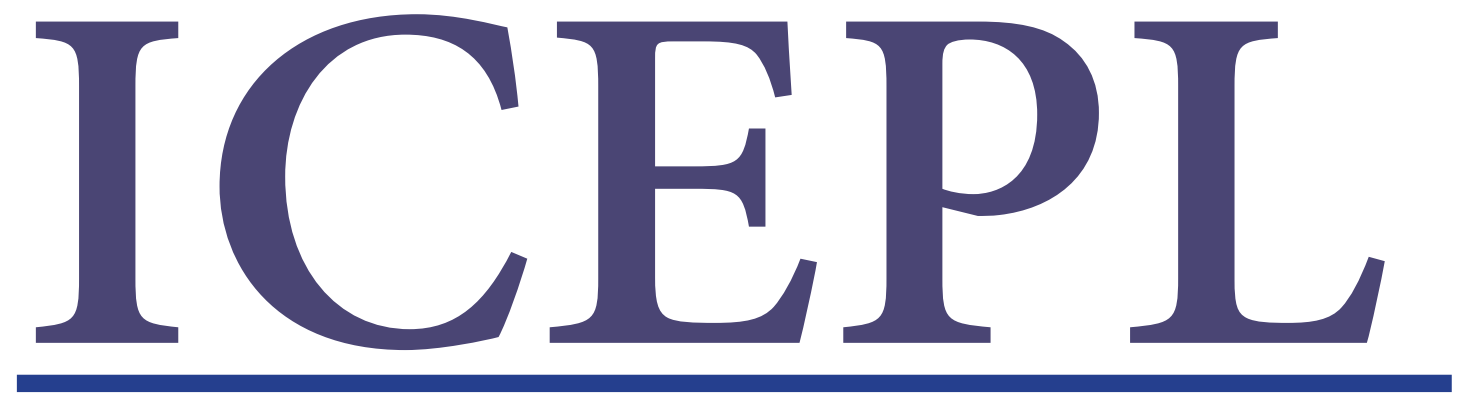

International Scientific

and Practical Conference

ECONOMICS, POLITICS, LAW:

TRENDS AND PROSPECTS

\title{
September 2019
}

Berlin, Germany

RELF Group \& OEAPS Inc.
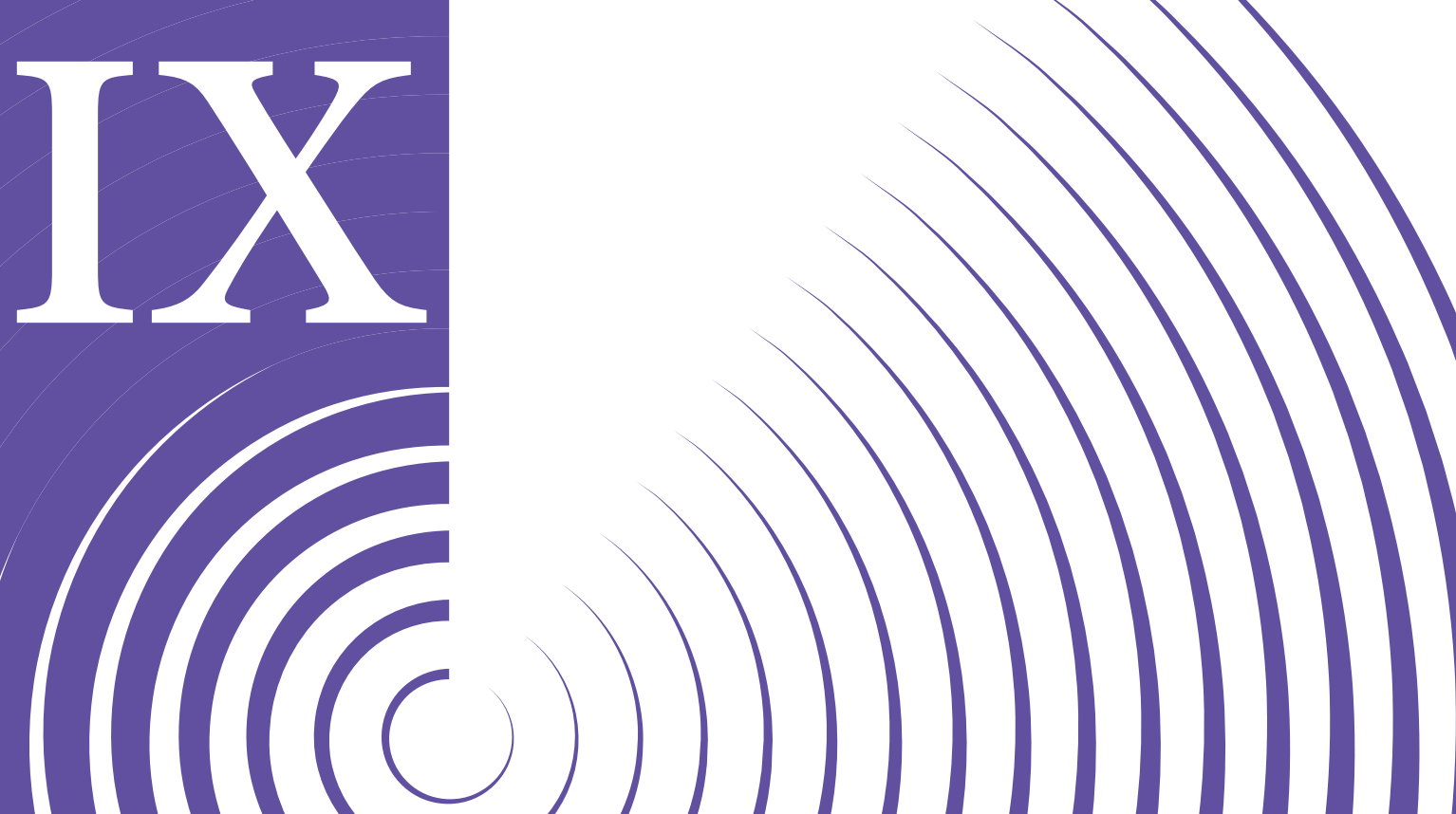


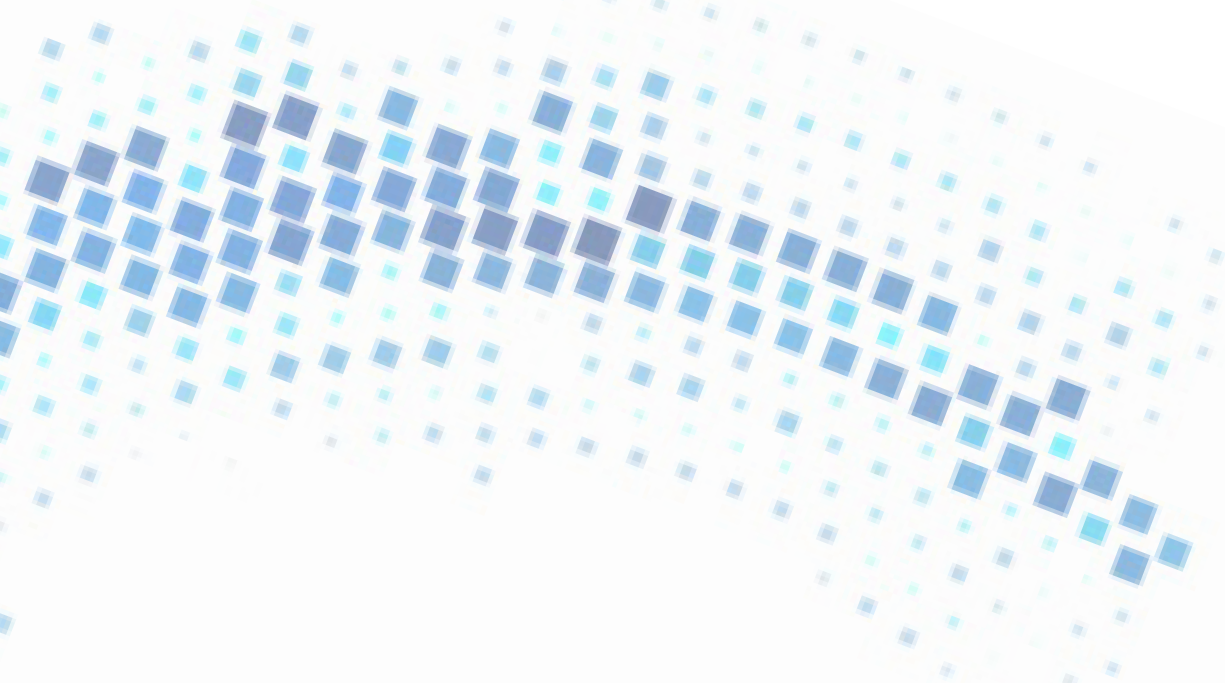

Approved at the meeting of the editorial board International Scientific and Practical Conference ECONOMICS, POLITICS, LAW: TRENDS AND PROSPECTS ICEPL September 2019: сб.науч.тр./ RELF Group \& OEAPS Inc.; редкол.: Флора Бертран (отв.ред.) [и др.]. Берлин, Германия : OEAPS Inc., 05. 2019. - 110 C.

Number layout 20.09.2019

Signed in print 25.09.2019

Published on 26.09.2019 
Conference paper Covered by Leading Indexing Databases

Open European Academy of Public Sciences aims to have all of its journals covered by the Science Citation Index Expanded (SCIE) and Scopus and Web of Science indexing systems. Several journals have already been covered by SCIE for several years and have received official Impact Factors. Some life science related journals are also covered by PubMed/MEDLINE and archived through PubMed Central (PMC). All of our journals are archived with the Spanish and Germany National Library.

All Content is Open Access and Free for Readers Journals published by Open European Academy of Public Sciences are fully open access: research articles, reviews or any other content on this platform is available to everyone free of charge. To be able to provide open access journals, we finance publication through article processing charges (APC); these are usually covered by the authors' institutes or research funding bodies. We offer access to science and the latest research to readers for free. All of our content is published in open access and distributed under a Creative Commons License, which means published articles can be freely shared and the content reused, upon proper attribution.

Open European Academy of Public Sciences Publication Ethics Statement Open European Academy of Public Sciences is a member of the Committee on Publication Ethics (COPE). Open European Academy of Public Sciences takes the responsibility to enforce a rigorous peerreview together with strict ethical policies and standards to ensure to add high quality scientific works to the field of scholarly publication. Unfortunately, cases of plagiarism, data falsification, inappropriate authorship credit, and the like, do arise. Open European Academy of Public Sciences takes such publishing ethics issues very seriously and our editors are trained to proceed in such cases with a zero tolerance policy. To verify the originality of content submitted to our journals, we use iThenticate to check submissions against previous publications.

Mission and Values

As a pioneer of academic open access publishing, we serve the scientific community since 2009. Our aim is to foster scientific exchange in all forms, across all disciplines. In addition to being at the root of Open European Academy of Public Sciences and a key theme in our journals, we support sustainability by ensuring the longterm preservation of published papers, and the future of science through partnerships, sponsorships and awards.

H U M B OLDT-UNIVERSITÄT ZU BERLIN

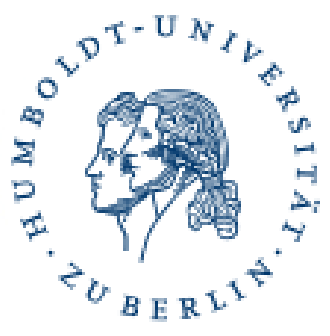


OEAPS is am inprint of RELF Group \& OEAPS INC.

Gran Via de les Corts Catalanes, 585, 08007 Barcelona, SP

Unter den Linden, 4, 10099 Berlin, DE

245 Peachtree Center Avenue, Suite 1900. Atlanta, GA 30303, USA

Copyright (C) 2019 ISA \& OEAPS EU Inc. All rights reserved.

This journal and the individual contributions contained in it are protected under copyright by Open European

Academy of Public Sciences, and the following terms and conditions apply to their use:

Photocopying

Single photocopies of single articles may be made for personal use as allowed by national copyright laws. Permission of the Publisher and payment of a fee is required for all other photocopying, including multiple or systematic copying, copying for advertising or promotional purposes, resale, and all forms of document delivery. Special rates are available for educational institutions that wish to make photocopies for non-profi t educational classroom use. For information on how to seek permission visit https://academy.scopuseu.com/

Derivative Works

Subscribers may reproduce tables of contents or prepare lists of articles including abstracts for internal circulation within their institutions. Permission of the Publisher is required for resale or distribution outside the institution. Permission of the Publisher is required for all other derivative works, including compilations and translations (please consult https://academy.scopuseu.com/).

Electronic Storage or Usage

Permission of the Publisher is required to store or use electronically any material contained in this journal, including any article or part of an article (please consult https://academy.scopuseu.com/).

Except as outlined above, no part of this publication may be reproduced, stored in a retrieval system or transmitted in any form or by any means, electronic, mechanical, photocopying, recording or otherwise, without prior written permission of the Publisher.

Notice

No responsibility is assumed by the Publisher for any injury and/or damage to persons or property as a matter of products liability, negligence or otherwise, or from any use or operation of any methods, products, instructions or ideas contained in the material herein. Because of rapid advances in the medical sciences, in particular, independent verifi cation of diagnoses and drug dosages should be made. Although all advertising material is expected to conform to ethical (medical) standards, inclusion in this publication does not constitute a guarantee or endorsement of the quality or value of such product or of the claims made of it by its manufacturer.

Funding body agreements and policies

OEAPS EU has established agreements and developed policies to allow authors whose articles appear in journals published by ISA\&OEAPS EU, to comply with potential manuscript archiving requirements as specifi ed as conditions of their grant awards. To learn more about existing agreements and policies please visit https://academy.scopuseu. com/

Publication information: «ECONOMICS, POLITICS, LAW: TRENDS AND PROSPECTS (ICEPL)», September (2019). (ISBN: 978-1695848658).

For September 2019, issues is scheduled for publication. Subscription prices are available upon request from the Publisher or from the RELF Group\&OEAPS Inc. Customer Service Department nearest you or from this journal's website (http://scopuseu.com/scopus/index.php/epl/index).

Further information is available on this journal and other ISA\&OEAPS EU products through OEAPS website (https:// academy.scopuseu.com). Subscriptions are accepted on a prepaid basis only and are entered on a calendar year basis. Issues are sent by standard mail (surface within Europe, air delivery outside Europe). Priority rates are available upon request. Claims for missing issues should be made within six months of the date of dispatch.

Orders, claims, and journal enquiries: Please visit our Support Hub pagehttps://academy.scopuseu.com for assistance. Author inquiries: You can track your submitted article at https://academy.scopuseu.com. You can track your accepted article at https://academy.scopuseu.com.

You are also welcome to contact Customer Support via https://academy.scopuseu.com Advertising information: If you are interested in advertising or other commercial opportunities please e-mail: office@ scopuseu.com and your enquiry will be passed to the correct person. Á who will respond to you within 48 hours. Printed in the Germany 
The conference is a major international forum for analyzing and discussing trends and approaches in research in the field of economics, politics and law. We provide a platform for discussions on innovative, theoretical and empirical studies of problems in these disciplines. Given the international focus, materials of a comparative nature are especially welcomed.

Doctors and candidates of science, scientists, specialists of various profiles and directions, applicants for academic degrees, teachers, graduate students, undergraduates and students are invited to participate in the conference.

\section{CONFERENCE SECTIONS}

Section 1 Finance, monetary circulation and credit Section 2 Accounting and taxation Section 3 Management and marketing Section 4 World economy Section 5 Business economics Section 6 Mathematical methods of economics Section 7 Relevant economic issues Section 8 Constitutional and municipal law Section 9 Civil and family law Section 10 Labor and business law section 11 Criminal law and criminology section 12 International law

- Section 13 entitled Administrative Section 14 law enforcement Section 15 Topical issues of jurisprudence Section 16 Topical issues in political science.

Additional criteria considered in the consideration of the submitted document are its accuracy, organization / presentation (ie logical flow) and recording quality. 



\section{Contents}

Надежда Николаевна Азанова

9-20

Практические основы механизма межбюджетных отношений

Елена Николаевна Савчик

21-30

Управление качеством пищевой продукции на основе применения

статистических методов

Kristina Maiorova

$31-40$

Problems of legal formalization and features of corporate obligations of members of so-cially-oriented NGOs

Максим Олегович Котельвин, Оксана Николаевна Кожевникова

Понятие причинения вреда при задержании лица, совершившего преступление

Магдалина Владимировна Желябовская

Ипотечное кредитование в России: приоритетные направления развития

Мальвина Хопей

69-75

Инновационность как проявление государственного присутствия на международной арене

Самира Абдулсамедовна Кадиева

76-82

Проблема мультикультурной идентичности в современном мире

Константин Адольфович Ржесик

Маркетинговый анализ рынка бытовой техники в условиях инновационного развития экономики

\section{Юлия Олеговна Гаврикова}

100-108

Некоторые проблемы правовой регламентации ответственности за преднамеренное банкротство 

International Scientific and Practical Conference

ECONOMICS, POLITICS, LAW: TRENDS AND PROSPECTS

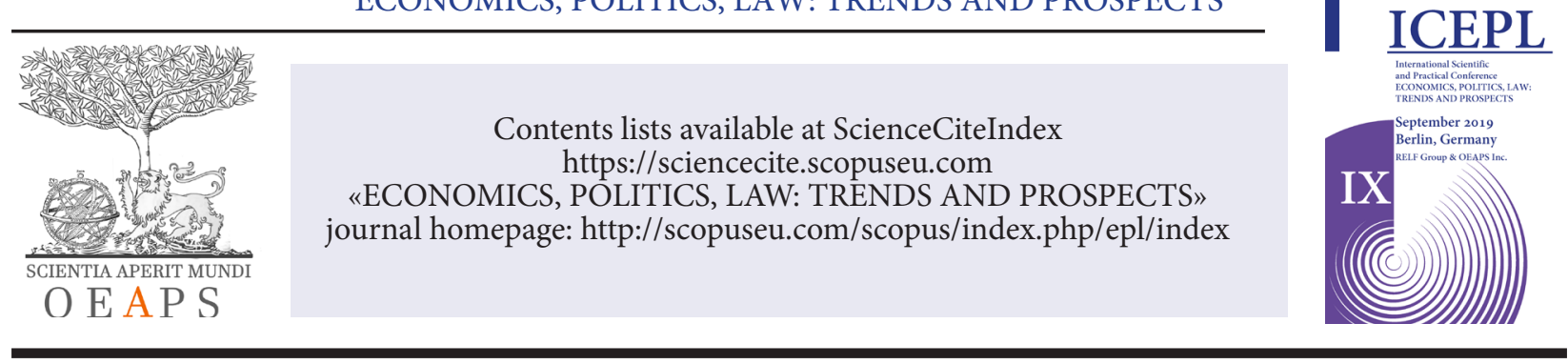

УДК 336.13

\title{
ПРАКТИЧЕСКИЕ ОСНОВЫ МЕХАНИЗМА МЕЖБЮДЖЕТНЫХ ОТНОШЕНИЙ
}

\author{
Азанова Надежда Николаевна \\ преподаватель, Шадринский финансово-экономический колледж, \\ Россия, г. Шадринск \\ pifa555@mail.ru
}

\section{Practical bases of the mechanism of interbudget relations}

\author{
Azanova Nadezhda Nikolaevna \\ Lecturer, Shadrinsk Financial and Economic College, Russia, Shadrinsk
}

\begin{abstract}
Аннотация: В современных условиях развития экономики России наблюдается рост зависимости местных органов власти от финансовых ресурсов вышестоящего бюджета. В статье анализируется механизм предоставления межбюджетных трансфертов в системе органов местного самоуправления.
\end{abstract}

Abstract: In the modern conditions of the development of the Russian economy, there is an increase in the dependence of local authorities on the financial resources of the higher budget. The article analyzes the mechanism for the provision of intergovernmental transfers in the system of local governments.

Ключевые слова: бюджет; местный бюджет; межбюджетные трансферты; межбюджетные отношения; доходы бюджета; расходы бюджета.

Keywords: budget; local budget; intergovernmental transfers; intergovernmental relations; budget revenues; budget expenses.

(c) 2019 The Author. Published by OEAPS Inc. This is an open access article under the CC BY-NC-ND license (http://creativecommons.org/licenses/by-nc-nd/4.0/) 
International Scientific and Practical Conference ECONOMICS, POLITICS, LAW: TRENDS AND PROSPECTS

Формы и порядок предоставления межбюджетных трансфертов

Шадринский район - самый крупный район Курганской области. В районе 92 села и деревни, которые представлены 35 муниципальными образованиями - сельсоветами. При реализации межбюджетных отношений Шадринский район является как получателем межбюджетных трансфертов, так и сам их предоставляет сельским поселениям, находящимся на территории Шадринского района. В табл. 1 показана динамика предоставления сумм межбюджетных трансфертов из областного бюджета.

Таблица 1. Динамика межбюджетных трансфертов из бюджета Курганской области бюджету Шадринского района в 2017-2018 гг.

\begin{tabular}{|l|r|r|r|r|}
\hline \multicolumn{1}{|c|}{ Показатель } & \multicolumn{2}{|c|}{ Сумма, тыс. руб. } & \multicolumn{2}{c|}{ Темп прироста } \\
\cline { 2 - 5 } & 2017 г. & 2018 г. & в сумме, \\
\hline $\begin{array}{l}\text { Безвозмездные по- } \\
\text { ступления из об- } \\
\text { ластного бюджета, } \\
\text { всего }\end{array}$ & 723147,4 & 528678,5 & $-194468,9$ & $-26,89$ \\
\hline Дотации & 293343,0 & 290350,0 & $-2993,0$ & $-1,02$ \\
\hline Субсидии & 184779,1 & 22745,8 & $-162033,3$ & $-87,69$ \\
\hline Субвенции & 245025,3 & 215582,7 & $-29442,6$ & $-12,02$ \\
\hline
\end{tabular}

Общая сумма межбюджетных трансфертов, причитающаяся из областного бюджета Шадринскому району в 2018 г. снизилась по сравнению с предыдущим годом на 26,89\%, что связано со значительным сокращением сумм субсидий (на 87,69\%). На данный факт повлияло значительное уменьшение совместного финансирования по ремонту гидротехнических сооружений в селах Шадринского района.

В табл. 2 показана динамика межбюджетных трансфертов, предоставляемых из районного бюджета бюджетам муниципальных образований. 
International Scientific and Practical Conference

ECONOMICS, POLITICS, LAW: TRENDS AND PROSPECTS

Таблица 2. Динамика межбюджетных трансфертов из бюджета Шадринского района бюджетам муниципальных образований в 2017-2018 гг.

\begin{tabular}{|c|c|c|c|c|}
\hline \multirow[t]{2}{*}{ Показатель } & \multicolumn{2}{|c|}{ Сумма, тыс. руб. } & \multicolumn{2}{|c|}{ Темп прироста } \\
\hline & 2017 г. & 2018 г. & в сумме & В $\%$ \\
\hline $\begin{array}{l}\text { Финансовая помощь в } \\
\text { виде трансфертной под- } \\
\text { держки, всего }\end{array}$ & 115084 & 133263,6 & $+18179,6$ & $+15,80$ \\
\hline $\begin{array}{lr}\text { Дотации на вырав- } \\
\text { нивание бюджетной } \\
\text { обеспеченности } \\
\text { регионального } \\
\text { муниципальных } \\
\text { разований, субвенции } \\
\text { на исполнение полн- } \\
\text { мочий органов госу- } \\
\text { дарственной } \\
\text { Курганской области по } \\
\text { расчету и предоставле- } \\
\text { нию дотаций }\end{array}$ & 48000 & 36216 & -11784 & $-24,55$ \\
\hline $\begin{array}{l}\text { Дотации на поддерж- } \\
\text { ку мер по обеспечению } \\
\text { сбалансированности } \\
\text { бюджетов из средств } \\
\text { областного бюджета и } \\
\text { местного бюджета рай- } \\
\text { она }\end{array}$ & 64312 & 93722 & +29410 & $+45,73$ \\
\hline $\begin{array}{l}\text { Субвенции на испол- } \\
\text { нение полномочий ор- } \\
\text { ганов государственной } \\
\text { власти Курганской об- } \\
\text { ласти по расчету и пре- } \\
\text { доставлениюсубвенций } \\
\text { бюджетам поселений на } \\
\text { осуществление полно- } \\
\text { мочий по первичному } \\
\text { воинскому учету }\end{array}$ & 2122 & 2201,6 & $+79,6$ & $+3,77$ \\
\hline
\end{tabular}




\begin{tabular}{|c|c|c|c|c|}
\hline $\begin{array}{l}\text { Субвенции из област- } \\
\text { ного бюджета на испол- } \\
\text { нение государственных } \\
\text { полномочий по предо- } \\
\text { ставлению мер соци- } \\
\text { альной поддержки ли- } \\
\text { цам, проживающим и } \\
\text { работающим в сельской } \\
\text { местности и рабочих } \\
\text { поселках }\end{array}$ & 650 & 1124 & +474 & $+72,92$ \\
\hline
\end{tabular}

Из бюджета Шадринского района бюджетам сельских муниципальных образований в 2018 г. выделено финансовой поддержки на сумму 113263,9 тыс. руб., что на 15,8\% больше, чем в 2017 г. Это связано со значительным увеличением сумм дотаций на поддержку мер по обеспечению сбалансированности бюджетов из средств областного бюджета и местного бюджета района на $45,73 \%$ и субвенций из областного бюджета на исполнение государственных полномочий по предоставлению мер социальной поддержки лицам, проживающим и работающим в сельской местности и рабочих поселках на72,92\%. В то же время прослеживается снижение сумм дотаций на выравнивание бюджетной обеспеченности из регионального фонда финансовой поддержки муниципальных образований, субвенции на исполнение полномочий органов государственной власти Курганской области по расчету и предоставлению дотаций на $24,55 \%$. Дотации на выравнивание бюджетной обеспеченности бюджетов поселений предусмотрены в составе расходов бюджета района с целью оказания дополнительной финансовой поддержки бюджетам поселений в связи с изменением объема их расходных обязательств и с целью более полного исполнения полномочий местных бюджетов.

В табл. 3 показана структура межбюджетных трансфертов, предоставляемых из районного бюджета бюджетам муниципальных образований. 
International Scientific and Practical Conference

ECONOMICS, POLITICS, LAW: TRENDS AND PROSPECTS

Таблица 3. Структура межбюджетных трансфертов из бюджета Шадринского района бюджетам муниципальных образований в 2017-2018 гг.

\begin{tabular}{|c|c|c|c|c|}
\hline \multirow[t]{2}{*}{ Показатель } & \multicolumn{2}{|c|}{2017 г. } & \multicolumn{2}{|c|}{2018 г. } \\
\hline & $\begin{array}{c}\text { Сумма, тыс. } \\
\text { руб. }\end{array}$ & $\begin{array}{c}\text { Удельный } \\
\text { вес, \% }\end{array}$ & $\begin{array}{c}\text { Сумма, тыс. } \\
\text { руб. }\end{array}$ & $\begin{array}{c}\text { Удельный } \\
\text { вес, \% }\end{array}$ \\
\hline $\begin{array}{l}\text { Финансовая помощь в } \\
\text { виде трансфертной под- } \\
\text { держки, всего }\end{array}$ & 115084 & 100,00 & 133263,6 & 100,00 \\
\hline $\begin{array}{l}\text { Дотации на вырав- } \\
\text { нивание бюджетной } \\
\text { обеспеченности из ре- } \\
\text { гионального ФФП муни- } \\
\text { ципальных образований, } \\
\text { субвенции на исполне- } \\
\text { ние полномочий органов } \\
\text { государственной власти } \\
\text { Курганской обл. по рас- } \\
\text { чету и предоставлению } \\
\text { дотаций }\end{array}$ & 48000 & 41,71 & 36216 & 27,18 \\
\hline $\begin{array}{l}\text { Дотации на поддержку } \\
\text { мер по обеспечению сба- } \\
\text { лансированности бюд- } \\
\text { жетов из средств област- } \\
\text { ного бюджета и местного } \\
\text { бюджета района }\end{array}$ & 64312 & 55,88 & 93722 & 70,33 \\
\hline $\begin{array}{l}\text { Субвенции на исполне- } \\
\text { ние полномочий органов } \\
\text { государственной власти } \\
\text { Курганской области по } \\
\text { расчету и предоставле- } \\
\text { нию субвенций бюдже- } \\
\text { там поселений на осу- } \\
\text { ществление полномочий } \\
\text { по первичному воинско- } \\
\text { му учету }\end{array}$ & 2122 & 1,84 & 2201,6 & 1,65 \\
\hline
\end{tabular}


Субвенции из областного бюджета на исполнение государственных полномочий по предоставлению мер социальной поддержки лицам, проживающим и работающим в сельской местности и рабочих поселках

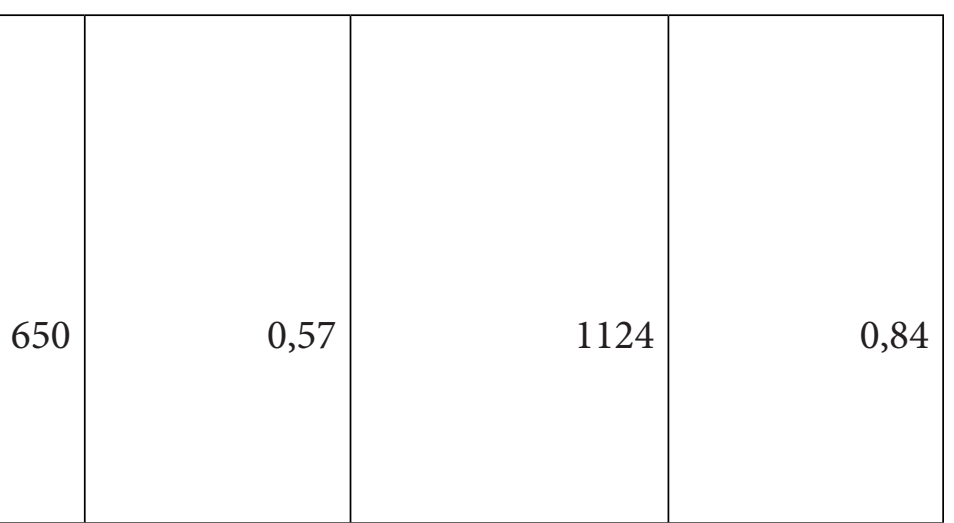

В структуре межбюджетных трансфертов, предоставляемых из районного бюджета наибольший удельный вес приходится на дотации на поддержку мер по обеспечению сбалансированности бюджетов из средств областного бюджета и местного бюджета района. Если в 2017 г. на их долю приходилось 55,88\% от общей суммы межбюджетных трансфертов, то в 2018 г. уже 70,33\%. Основной причиной является снижение уровня доходов бюджетов сельских поселений при неизменности или даже увеличении расходных обязательств. На втором месте находятся дотации на выравнивание бюджетной обеспеченности из регионального фонда финансовой поддержки муниципальных образований, субвенции на исполнение полномочий органов государственной власти Курганской обл. по расчету и предоставлению дотаций. Их доля в 2017 г. составляла 41,71\%, в 2018 г. произошло снижение удельного веса до 27,18\%. Остальные виды межбюджетных трансфертов имеют незначительный удельный вес.

На рис. 1 показана динамика общих сумм межбюджетных трансфертов, полученных бюджетом Шадринского района из бюджета Курганской области и выделенных бюджетом Шадринского района бюджетам сельских муниципальных образований. 


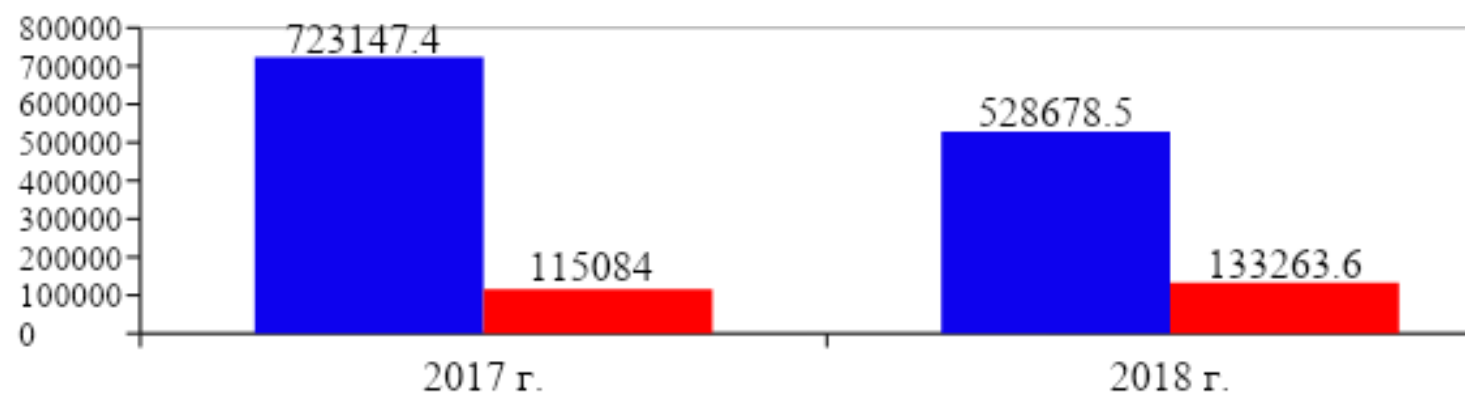
Межбюджетные трансферты, полученные бюджетом Шадринского района из
бюджета Курганской области

Рисунок 1. Динамика полученных и предоставленных межбюджетных трансфертов бюджета Шадринского района в 2017-2018 гг.

По данным рисунка следует, что объем полученных районным бюджетом межбюджетных трансфертов в 2017 г. в 6 раз больше, чем трансфертов предоставленных, в 2018 г. - в 4 раза. Это связано с использованием части полученной финансовой помощи непосредственно на нужды района без дальнейшей их передачи сельским поселениям.

Доля расходов на предоставление межбюджетных трансфертов в бюджете Шадринского района составляет в 2017 г. - 19,02\%. В 2018 г. ситуация практически не изменилась - Іоля предоставляемых сельским поселениям межбюджетных трансфертов возросла лишь на 2,94 процентных пункта и составила $21,96 \%$ от общей суммы расходов бюджета Шадринского района. Подобная ситуация связана с тем, что несмотря на увеличение суммы межбюджетных трансфертов за анализируемый период на 15,8\%, расходная часть бюджета возросла лишь на $0,3 \%$.

На примере Краснонивенского сельского совета Шадринского района рассмотрим предоставление межбюджетных трансфертов из районного бюджета в 2018 г.

В состав Краснонивенского сельского совета входит 4 сельских поселения (с. Красная Нива, д. Макарово, д. Одина, д. Симаково) с численностью постоянного населения 1900 чел.

В соответствии с решением Шадринской районной Думы распределение межбюджетных трансфертов в 2018 г., предназначенных для перечисления Краснонивенскому сельскому совету из бюджета Шадринского района, представлено в табл. 4. 
International Scientific and Practical Conference ECONOMICS, POLITICS, LAW: TRENDS AND PROSPECTS

Таблица 4. Состав и структура межбюджетных трансфертов Краснонивенскому сельскому совету из бюджета Шадринского района в 2018 г.

\begin{tabular}{|c|c|c|}
\hline Вид межбюджетных трансфертов & $\begin{array}{l}\text { Сумма, тыс. } \\
\text { руб. }\end{array}$ & $\begin{array}{l}\text { Удельный вес, } \\
\%\end{array}$ \\
\hline $\begin{array}{l}\text { Дотации на выравнивание бюджетной обеспеченности } \\
\text { из районного ФФП поселений за счет средств областного } \\
\text { бюджета }\end{array}$ & 1306 & 23,70 \\
\hline $\begin{array}{l}\text { Дотации на поддержку мер по обеспечению сбалансиро- } \\
\text { ванности бюджетов за счет средств областного бюджета }\end{array}$ & 3472 & 63,01 \\
\hline $\begin{array}{l}\text { Дотации на поддержку мер по обеспечению сбалансиро- } \\
\text { ванности бюджетов }\end{array}$ & 604 & 10,96 \\
\hline $\begin{array}{l}\text { Субвенции на исполнение полномочий по первичному во- } \\
\text { инскому учету }\end{array}$ & 100 & 1,81 \\
\hline $\begin{array}{l}\text { Субвенции на меры социальной поддержки лиц, прожи- } \\
\text { вающих и работающих в сельской местности и в рабочих } \\
\text { поселках }\end{array}$ & 28 & 0,52 \\
\hline Всего & 5510 & 100,00 \\
\hline
\end{tabular}

В структуре межбюджетных трансфертов Краснонивенского сельского совета наибольшая их доля приходится на дотации на поддержку мер по обеспечению сбалансированности бюджетов за счет средств областного бюджета - 63,01\%. Это связано со значительной недоимкой по собственным доходам бюджета в части налоговых и неналоговых доходов. 23,7\% межбюджетных трансфертов идет на дотации на выравнивание бюджетной обеспеченности из районного ФФП поселений за счет средств областного бюджета. Средства предназначены для выполнения переданных на местный уровень государственных полномочий.

В общем объеме средств на финансовую поддержку сельских поселений из бюджета Шадринского района, приходящаяся на Краснонивенский сельсовет, составляет 4,13\%. Общая сумма фактически предоставленных межбюджетных трансфертов составила 5378 тыс. руб., что на 2,4\% меньше первоначально запланированных сумм. Основной причиной стала сумма недоимки по налоговым доходам районного бюджета, что сказалось на сокращении фактических сумм межбюджетных трансфертов поселениям.

Доходная часть бюджета Краснонивенского сельского поселения в 2018 г. представлена в табл. 5. 
International Scientific and Practical Conference

ECONOMICS, POLITICS, LAW: TRENDS AND PROSPECTS

Таблица 5. Состав и структура доходов бюджета Краснонивенского сельского совета по итогам исполнения бюджета в 2018 г.

\begin{tabular}{|l|r|r|}
\hline \multicolumn{1}{|c|}{ Вид доходов } & \multicolumn{1}{|c|}{$\begin{array}{c}\text { Сумма, } \\
\text { тыс. руб. }\end{array}$} & $\begin{array}{c}\text { Удельный } \\
\text { вес, \% }\end{array}$ \\
\hline Собственные доходы & 1549 & 22,36 \\
\hline Межбюджетные трансферты & 5378 & 77,64 \\
\hline Итого доходов & 6927 & 100,00 \\
\hline
\end{tabular}

Собственные доходы бюджета сельского поселения составляют лишь 22,36\% от общей их суммы. Следовательно, межбюджетные трансферты представляют особую значимость для бюджета Краснонивенского сельского совета.

Таким образом, рассмотрев направления и объемы межбюджетных трансфертов в составе бюджета Шадринского района можно констатировать тот факт, что финансовая помощь составляет существенный объем как доходов районного бюджета, так и его расходов. Однако, органам местного самоуправления необходимо проводить определенную работу по снижению зависимости от вышестоящих бюджетных уровней.

\section{Список литературы}

1. Положение о бюджетном процессе в Шадринском районе : Решение Шадринской районной Думы от 16.07.2009 г. №141. - Доступ из справочно-правовой системы «Консультант плюс». - Режим доступа: http://www.consultant.ru.

2. Об утверждении Порядка предоставления межбюджетных трансфертов из бюджета Шадринского района бюджетам сельских поселений Шадринского района : Решение Шадринской районной Думы от 25.01.2018 г. №2 - Доступ из справочно-правовой системы «Консультант плюс». - Режим доступа: http://www.consultant.ru.

3. Пояснительная записка к проекту решения о бюджете Шадринской районной Думы [Электронный ресурс] - Режим доступа: http://amrshadr.ru/down/r-9.html, свободный.

\section{The text of the article in English}

Forms and procedures for the provision of inter-budget transfers

Shadrinsky district is the largest district of the Kurgan region. In the region of 92 villages and villages, which are represented by 35 municipalities - village councils. When implementing interbudgetary relations, the Shadrinsky district is both the recipient of inter-budgetary transfers, and it itself provides them to rural settlements located on the territory of the Shadrinsky district. In the table. Figure 1 shows the dynamics of the provision of intergovernmental transfers from the regional budget. 
International Scientific and Practical Conference

ECONOMICS, POLITICS, LAW: TRENDS AND PROSPECTS

Table 1 - Dynamics of inter-budget transfers from the budget of the Kurgan region to the budget of the Shadrinsky district in 2017-2018. (RU vers.)

The total amount of inter-budget transfers due from the regional budget to the Shadrinsky district in 2018 decreased compared to the previous year by $26.89 \%$, which is associated with a significant reduction in the amount of subsidies (by $87.69 \%$ ). This fact was affected by a significant decrease in joint financing for the repair of hydraulic structures in the villages of Shadrinsky district.

In the table. 2 shows the dynamics of inter-budget transfers provided from the district budget to the budgets of municipalities.

Table 2 - Dynamics of inter-budget transfers from the budget of the Shadrinsky district to the budgets of municipalities in 2017-2018.(RU vers.)

From the budget of the Shadrinsky district, budgets of rural municipalities in 2018 were allocated financial support in the amount of 113,263.9 thousand rubles, which is $15.8 \%$ more than in 2017 . This is due to a significant increase in the amount of subsidies to support measures to ensure the balance of budgets from the regional budget and the local budget of the district by $45.73 \%$ and subventions from the regional budget for the execution of state powers to provide social support measures to people living and working in rural areas and working villages $72,92 \%$. At the same time, there is a decrease in the amount of subsidies for equalizing budgetary provision from the regional fund for financial support of municipalities, subventions for the fulfillment of the powers of public authorities of the Kurgan region to calculate and provide subsidies by $24.55 \%$. Subsidies for equalizing the budgetary provision of the budgets of settlements are provided as part of the district budget expenditures in order to provide additional financial support to the budgets of the settlements in connection with a change in the volume of their spending obligations and with a view to more fully fulfilling the powers of local budgets.

In the table. Figure 3 shows the structure of inter-budget transfers provided from the district budget to the budgets of municipalities.

Table 3 - The structure of inter-budget transfers from the budget of the Shadrinsky district to the budgets of municipalities in 2017-2018.(RU vers.)

In the structure of inter-budget transfers provided from the district budget, the largest share falls on subsidies to support measures to ensure balanced budgets from the regional budget and the local budget of the district. If in 2017 they accounted for $55.88 \%$ of the total amount of inter-budget transfers, then in 2018 it was already $70.33 \%$. The main reason is a decrease in the income level of 
International Scientific and Practical Conference

ECONOMICS, POLITICS, LAW: TRENDS AND PROSPECTS

budgets of rural settlements with a constant or even an increase in spending obligations. In second place are subsidies for equalizing budgetary provision from the regional fund for financial support of municipalities, subventions for the execution of powers of state authorities of the Kurgan region. on the calculation and provision of subsidies. Their share in 2017 was $41.71 \%$, in 2018 there was a decrease in the specific gravity to $27.18 \%$. The remaining types of intergovernmental transfers have a small proportion.

In fig. Figure 1 shows the dynamics of the total amounts of inter-budget transfers received by the budget of the Shadrinsky district from the budget of the Kurgan region and allocated by the budget of the Shadrinsky district to the budgets of rural municipalities.

Figure 1 - Dynamics of received and provided inter-budget transfers of the budget of the Shadrinsky district in 2017-2018.(RU vers.)

According to the figure, it follows that the volume of inter-budget transfers received by the district budget in 2017 is 6 times more than the transfers provided, in 2018 - 4 times. This is due to the use of part of the financial assistance received directly for the needs of the district without their further transfer to rural settlements.

The share of expenses for the provision of intergovernmental transfers in the budget of the Shadrinsky district in 2017 is $19.02 \%$. In 2018, the situation remained virtually unchanged - the share of inter-budget transfers provided to rural settlements increased by only 2.94 percentage points and amounted to $21.96 \%$ of the total budget expenditures of the Shadrinsky district. This situation is due to the fact that despite an increase in the amount of inter-budget transfers for the analyzed period by $15.8 \%$, the expenditure side of the budget increased by only $0.3 \%$.

Using the example of the Krasnonivensky Village Council of the Shadrinsky District, we will consider the provision of inter-budget transfers from the district budget in 2018. The

Krasnonivensky Village Council includes 4 rural settlements (the village of Krasnaya Niva, the village of Makarovo, the village of Odina, the village of Simakovo) with a permanent population of 1900 people

In accordance with the decision of the Shadrinsk District Duma, the distribution of inter-budget transfers in 2018, intended for transfer to the Krasnonivensky Village Council from the budget of the Shadrinsk District, is presented in Table. 4.

Table 4 - Composition and structure of intergovernmental transfers to the Krasnonivensky village council from the budget of the Shadrinsky district in 2018. (RU vers.) 
International Scientific and Practical Conference

ECONOMICS, POLITICS, LAW: TRENDS AND PROSPECTS

The structure of inter-budgetary transfers Krasnonivenskogo village council largest proportion accounted for grants to support measures to balance the budget at the expense of the regional budget $-63.01 \%$. This is due to a significant shortfall in its own budget revenues in terms of tax and non-tax revenues. $23.7 \%$ of inter-budget transfers goes to subsidies to equalize budgetary provision from the district FFP of settlements at the expense of the regional budget. The funds are intended for the fulfillment of state powers transferred to the local level.

In the total amount of funds for financial support of rural settlements from the budget of the Shadrinsky district, accounted for by the Krasnonivensky Village Council, is $4.13 \%$. The total amount of actually provided intergovernmental transfers amounted to 5378 thousand rubles, which is $2.4 \%$ less than the originally planned amounts. The main reason was the amount of arrears in tax revenues of the district budget, which affected the reduction in the actual amount of intergovernmental transfers to settlements.

The revenue part of the budget of the Krasnonivensky rural settlement in 2018 is presented in Table 5.

Table 5 - Composition and structure of the budget revenues of the Krasnonivensky Village Council based on the results of budget execution in 2018. (RU vers.)

budgetOwn income of the budget of the rural settlement make up only $22.36 \%$ of their total amount. Consequently, intergovernmental transfers are of particular importance for the budget of the Krasnonivensky Village Council.

Thus, having examined the directions and volumes of inter-budget transfers within the budget of the Shadrinsky district, we can state the fact that financial assistance makes up a significant amount of both the revenues of the district budget and its expenses. However, local governments need to do some work to reduce their dependence on higher budget levels.

\section{References}

1. Regulation on the budget process in the Shadrinsky district: Decision of the Shadrinsky district Duma of July 16, 2009 No. 141. - Access from the consultant plus reference system. - Access mode: http://www.consultant.ru.

2. On approval of the Procedure for the provision of inter-budget transfers from the budget of the Shadrinsky district to the budgets of rural settlements of the Shadrinsky district: Decision of the Shadrinsky district Duma of January 25, 2018 No. 2 - Access from the consultant plus legal system. - Access mode: http://www.consultant.ru.

3. Explanatory note to the draft decision on the budget of the Shadrinsk District Duma [Electronic resource] - Access mode: http://amrshadr.ru/down/r-9.html, free. 
International Scientific and Practical Conference

ECONOMICS, POLITICS, LAW: TRENDS AND PROSPECTS

Contents lists available at ScienceCiteIndex https://sciencecite.scopuseu.com «ECONOMICS, POLITICS, LAW: TRENDS AND PROSPECTS» $\operatorname{sen} 20$ SCIENTIA APERIT MUNDI journal homepage: http://scopuseu.com/scopus/index.php/epl/index

O E AP S

УДК 658.62:664:005.311.121

\section{Управление качеством пищевой продукции на основе применения статистических методов \\ статистических методов}

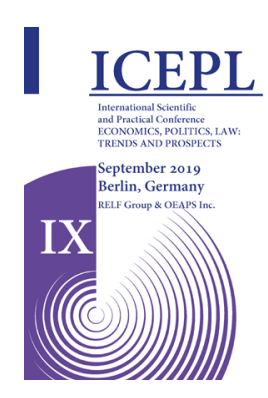

Савчик Елена Николаевна кандидат экономических наук, доцент, дочент кафедры управления качеством, стандартизации и документационного обеспечения управления, Сибирский государственный университет науки и технологий имени академика М.Ф. Решетнева, Россия, Красноярск E-mail: savchik_elena@mail.ru

\section{Food products quality management based on statistical methods}

Elena N. Savchik Cand. Sc., docent, associate professor at the Department of quality management, standardization and documentat management, Reshetnev Siberian State University of Science and Technology,

Russia, Krasnoyarsk

Аннотация: В работе рассмотрено применение статистических методов контроля качества продукции на предприятии пищевой промышленности. Даны рекомендации по внедрению статистических методов в деятельность предприятия, а также приведены результаты анализа стабильности процесса производства продукции при помощи контрольной карты и гистограммы.

Abstract: The paper considers the application of statistical methods of product quality control in the food industry. The recommendations on the implementation of statistical methods in the activities of the enterprise, as well as the results of the analysis of the stability of the production process with the help of a control card and a histogram.

(C) 2019 The Author. Published by OEAPS Inc. This is an open access article under the CC BY-NC-ND license (http://creativecommons.org/licenses/by-nc-nd/4.0/) 
International Scientific and Practical Conference

ECONOMICS, POLITICS, LAW: TRENDS AND PROSPECTS

Ключевые слова: управление качеством; контроль; статистические методы; процесс; продукция; контрольные карты.

Keywords: quality management; control; statistical methods; process; products; control cards.

На сегодняшний день наблюдается активное развитие пищевой промышленности, что способствует увеличению числа предприятий и наличию высокой конкуренции. В связи с чем, необходимо постоянно удовлетворять растущие требования потребителей к качеству продукции. При этом необходимо отметить, что для предприятий пищевой промышленности ключевым также является обеспечение безопасности выпускаемой продукции. Поэтому одной из основных задач для предприятий является контроль качества и безопасности продукции. От успешного управления качеством продукции зависит уровень продовольственной безопасности страны, материальное благополучие и качество жизни населения, иначе производитель рискует не только своей репутацией и занимаемым положением на рынке, но и может понести юридическую ответственность, если употребление продукции повлекло за собой причинение вреда жизни или здоровью потребителя. Все это указывает на необходимость внедрения современных методов управления качеством. Для этих целей могут быть использованы статистические методы, применение которых, позволит принять обоснованное решение о соответствии продукции предъявляемым к ней требованиям.

В настоящее время существует множество различных статистических методов, но на предприятиях они применяются достаточно редко, что обусловлено отсутствием знаний у сотрудников в области их применения и понимания целесообразности их использования при анализе данных показателей качества и безопасности продукции, а также технологического процесса. В связи с чем, начинать освоение статистических методов рекомендуется с применения элементарных методов в области управления качеством: контрольный листок, диаграмма Парето, диаграмма Исикавы, диаграмма разброса, гистограмма, стратификация и контрольные карты [3-5].

При выборе статистических методов предприятиям необходимо учитывать специфику своей деятельности, особенности производственного процесса, действующую систему контроля и наличие необходимых средств измерений, а также компетентность работников, осуществляющих сбор и обработку статистических данных.

Ответственным за внедрение статистических методов управления качеством на предприятии, как правило, является отдел технического контроля, но также могут быть привлечены и другие структурные подразделения, сотрудники, которых обладают необходимыми знаниями в области статистического управления процессами, что, как правило, достигается путем обучения персонала в данной области. Далее предприятию необходимо определить объект для внедрения статистических методов (например, продукция, процесс), определить контролируемые показатели качества, а также средства и методы контроля. Назначить ответственных должностных лиц за сбор статистических данных и их обработку при помощи соответ- 
ствующих методов, которые определяются на основе анализа имеющейся в организации на сегодняшний день информации по объекту контроля и возможности применения того или иного статистического метода. Для решения определенной производственной проблемы и поиска путей ее решения можно выбрать несколько разных статистических методов, а их графическое представление позволит наглядно увидеть закономерности, трудно различимые в простой таблице с набором цифр. Также могут быть разработаны планы применения статистических методов управления качеством продукции для конкретного объекта или показателя качества, реализация, которых позволит предприятию со временем понять правильно ли был осуществлён выбор статистических методов и насколько их применение целесообразно для предприятия, что в дальнейшем может привести к их корректировки.

Важно, чтобы внедрение статистических методов было направлено не только на выявление несоответствующей продукции или процесса, но и способствовало проведению корректирующих действий, направленных на улучшение качества продукции, оптимизацию производственных процессов, повышению эффективности производства и компетентности сотрудников, а также при минимальных затратах получать максимальный эффект.

С целью демонстрации преимущества и легкости применения элементарных статистических методов, нами проведен анализ качества хлеба ржаного бородинского формового штучного массой 0,8-1кг, который выпускается в соответствии с требованиями ГОСТ 2077-84 «Хлеб ржаной, ржано-пшеничный и пшенично-ржаной. Технические условия» [1].

На сегодняшний день для промышленных предприятий одной из важнейших задач является определение факторов, вызывающих отклонения процесса от заданных требований, а также исключение их влияния. С целью контроля состояния процесса производства хлеба во времени и воздействия на него до того, как он может выйти из-под контроля можно использовать контрольные карты. Также контрольные карты служат методом сбора данных для анализа качества продукции. Основные положения по применению и интерпретации контрольных карт Шухарта и соответствующих методов статистического управления процессами установлены в ГОСТ Р ИСО 7870-2-2015 «Статистические методы. Контрольные карты. Часть 2. Контрольные карты Шухарта», согласно которого, по типу используемых выборочных данных (или по способу восприятия признака качества) контрольные карты подразделяются на два класса - контрольные карты для количественных данных: средних и размахов ( $\overline{\mathrm{X}}$ - и R-карты); средних и стандартных отклонений ( $\overline{\mathrm{X}}$ - и S-карты); медиан и размахов (M- и R-карты); индивидуальных значений и скользящих размахов (x- и MR-карты)) и альтернативных данных (доли несоответствующих единиц продукции (р-карта); числа несоответствующих единиц продукции в выборке (np-карта); числа несоответствий в выборке (с-карта); числа несоответствий, приходящихся на единицу продукции (u-карта)) [2].

В результате сбора данных на одном из предприятий пищевой отрасли нами было установлено, что одним из видов брака является несоответствие пористости хлеба. В связи с этим, 
на основе статистических данных нами построена ( $\overline{\mathrm{X}}-\mathrm{R})$-карта по показателю «пористость» (рисунок 1). Данная карта используется для анализа и управления процессами, показатели качества которых представляют собой непрерывные величины и несут наибольшее количество информации о процессе [3].

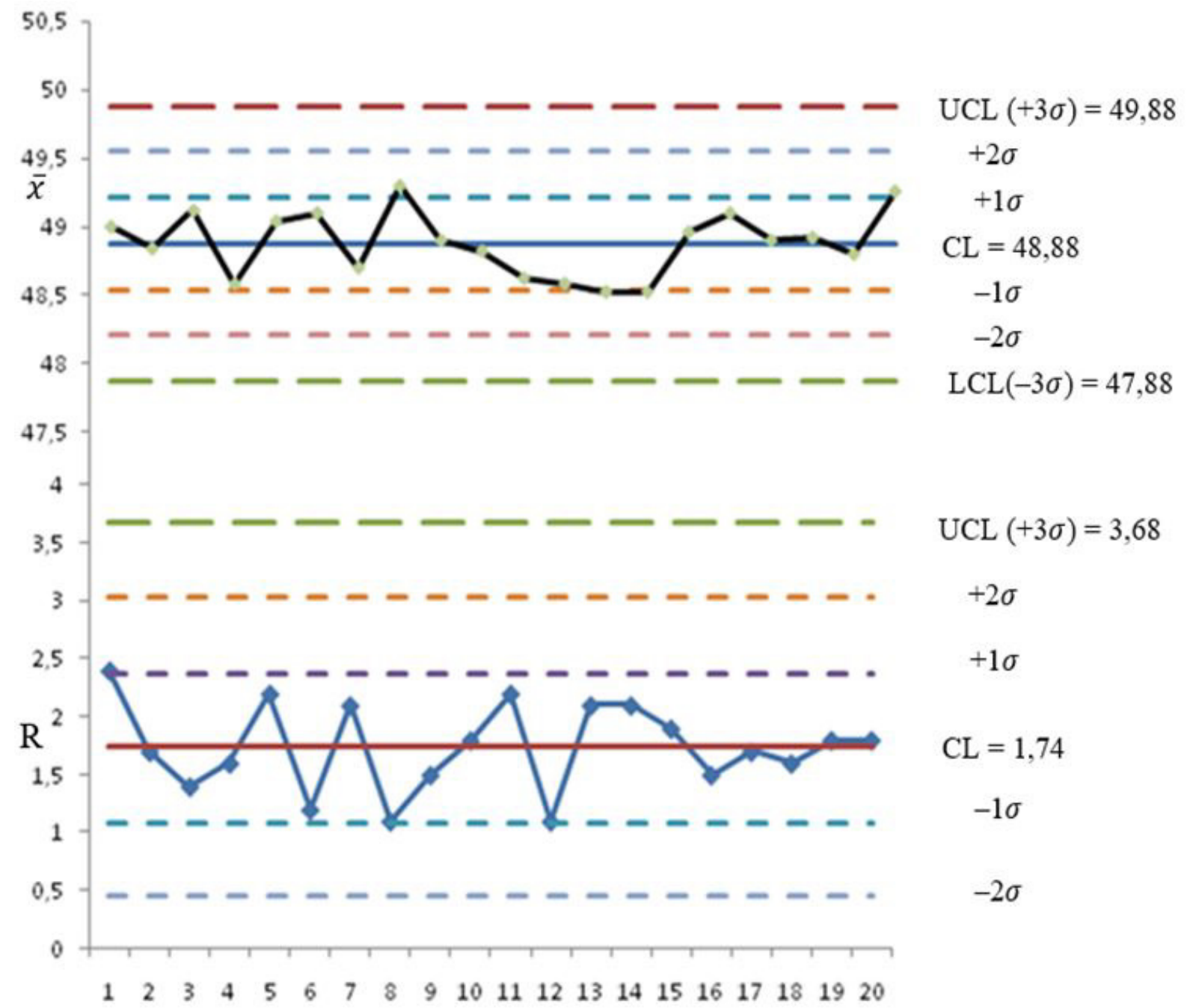

Рисунок 1. ( $\overline{\mathrm{x}}-\mathrm{R})$ - Карта по показателю «пористость»

Анализ контрольной карты показал нестабильность процесса. О чем свидетельствует наличие «тренда», причины возникновения которого могли быть связаны с изменением состава сырья, а также малая пористость могла возникнуть при использовании свежемолотой муки и недостаточной расстойке теста. В связи с чем необходимо обеспечить производственный 
процесс сырьем, соответствующего качества и строгим соблюдением персоналом рецептуры. Кроме того, вследствие сбора в каждой выборки некоторого числа измерений из различных партий или проведение улучшений в процессе после вычисления контрольных пределов приводит к приближению точек к центральной линии (CL). В этом случае персоналу рекомендуется оценить рациональность объема подгрупп, проконтролировать соблюдение метода оценки пористости хлеба.

Также нами проведен анализ пористости хлеба с помощью гистограммы (рисунок 2), которая позволяет зрительно оценить распределение статистических данных и определить стабильность процесса, а также выяснить возможные причины обнаруженных отклонений от заданных норм и разработать корректирующие действия по совершенствованию технологического процесса и качества продукции. Решение о соответствии принимается на основе анализа формы гистограммы, а также ее расположения относительно технологического допуска. Существуют различные типы гистограмм: свидетельствующие о стабильности процесса (обычный тип); нестабильности процесса (гистограмма вытянутая вправо/влево, гистограмма в форме обрыва, гистограмма двугорбая, гистограмма в форме плато, гистограмма с прогалами, гистограмма с отдельным островком) [3, 4].

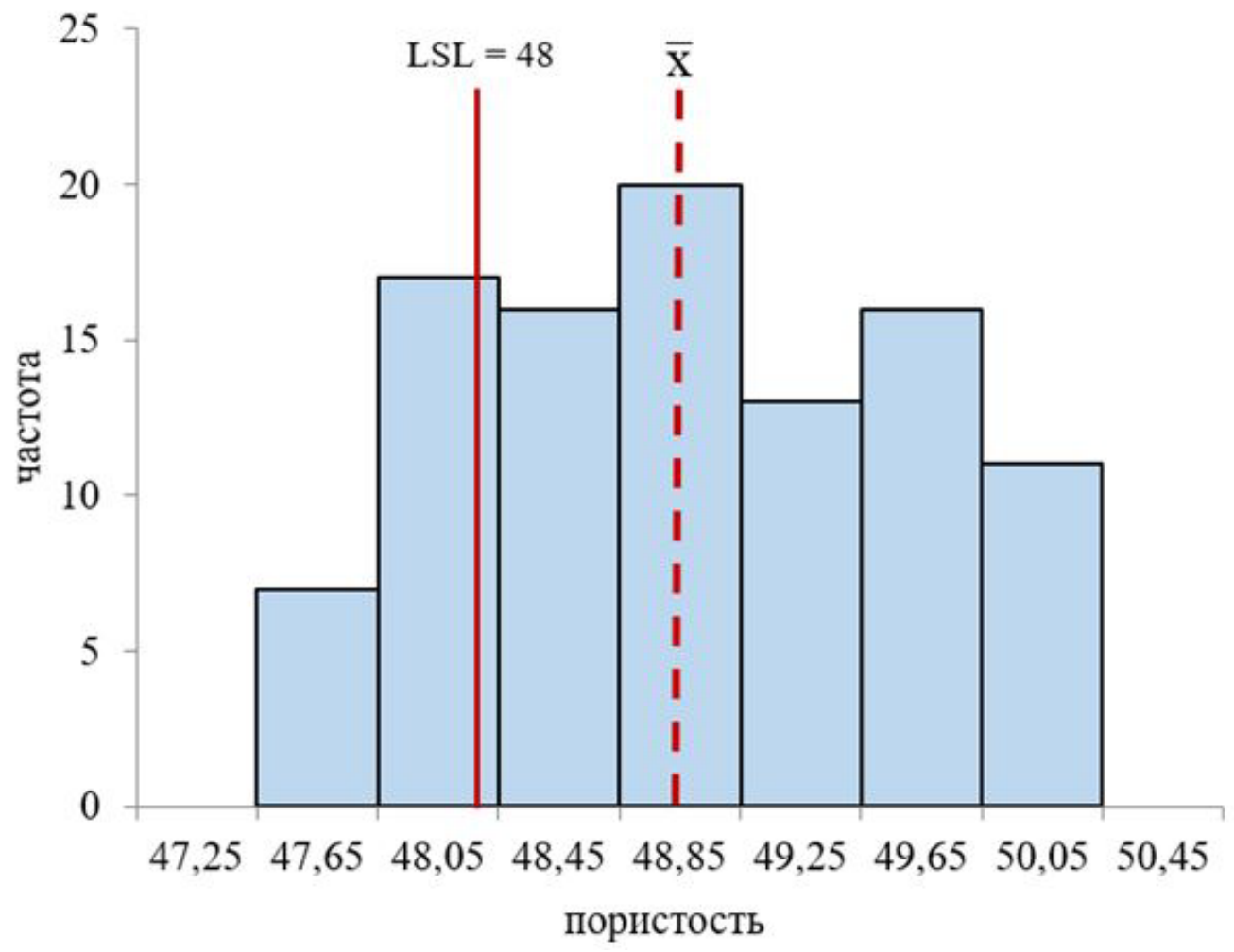

Рисунок 2. Гистограмма по показателю «Пористость» 
International Scientific and Practical Conference

ECONOMICS, POLITICS, LAW: TRENDS AND PROSPECTS

На рисунке 2 видно, что гистограмма имеет форму с прогалами, что обусловлено шириной интервала, которая не кратна единице измерения, а также возможно наличие ошибки, допущенной работником при расчете показателя качества хлеба «пористость» по соответствующим методикам. В связи с тем, что показатель пористости хлеба ржаного должен быть не менее $48 \%$, то выход за нижнюю границу допуска свидетельствует о наличии брака.

Таким образом, производитель может контролировать качество продукции и по статистическим данным судить о состоянии технологического процесса. Благодаря этому своевременно обнаруживать несоответствия и предпринимать корректирующие действия, что позволит процессам функционировать в управляемых условиях и гарантировать высокое качество хлебобулочной продукции, поставляемой потребителю.

\section{Список литературы}

1. ГОСТ 20077-84 Хлеб ржаной, ржано-пшеничный и пшенично-ржаной. Технические условия. - Введен впервые 01.01.1986. - М: Стандартинформ, 2006. - 6 с.

2. ГОСТ Р ИСО 7870-2-2015 Статистические методы. Контрольные карты. Часть 2. Контрольные карты Шухарта. - Введ. 2016-12-01. - М.: Стандартинформ, 2016.- 46 с.

3. Ефимов, В.В. Статистические методы в управлении качеством продукции / В.В. Ефимов, Т. В. Барт. - 2-е изд., стер.. - Москва: КноРус, 2013. - 240 с.

4. Кумэ, Х. Статистические методы повышения качества: Перевод с англ./Под ред.Х. Кумэ. - М.: Финансы и статистика, 1990. - 304 с.

5. Управление качеством продукции. Инструменты и методы менеджмента качества / С. В. Пономарев, С. В. Мищенко, В. Я. Белобрагин, В. А. Самородов, Б. И. Герасимов, А. В. Трофимов, С. А. Пахомова, О. С. Пономарева. - М.: РИА «Стандарты и качество». -2005. - 248 c. 


\section{The text of the article in English}

Today, there is an active development of the food industry, which contributes to an increase in the number of enterprises and the presence of high competition. In this connection, it is necessary to constantly meet the growing demands of consumers on product quality. It should be noted that for the food industry, the key is also to ensure the safety of products. Therefore, one of the main tasks for enterprises is to control the quality and safety of products. The level of food security of the country, material well-being and quality of life of the population depend on successful product quality management, otherwise the manufacturer risks not only his reputation and position in the market, but may also be legally liable if the use of the product caused harm to the life or health of the consumer. All this indicates the need for the introduction of modern quality management methods. For these purposes, statistical methods can be used, the use of which will make it possible to make an informed decision on the conformity of products with the requirements for it.

Currently, there are many different statistical methods, but they are rarely used in enterprises, due to the lack of knowledge among employees in the field of their application and understanding of the appropriateness of their use in the analysis of these indicators of product quality and safety, as well as the technological process. In this connection, it is recommended to begin the development of statistical methods with the use of elementary methods in the field of quality management: a checklist, a Pareto chart, Ishikawa chart, a scatter chart, a histogram, stratification and control charts [3-5].

When choosing statistical methods, enterprises need to take into account the specifics of their activities, the features of the production process, the current control system and the availability of the necessary measuring instruments, as well as the competence of workers who collect and process statistical data.

The department for technical control, as a rule, is responsible for the implementation of statistical methods of quality management at the enterprise, but other structural units, employees who possess the necessary knowledge in the field of statistical process control, can also be involved, which, as a rule, is achieved by training personnel in this area. Next, the company needs to determine the object for the implementation of statistical methods (for example, products, process), define controlled quality indicators, as well as means and methods of control. To appoint responsible officials for the collection of statistical data and their processing using appropriate methods, which are determined on the basis of the analysis of the information currently available in the organization on the object of control and the possibility of applying one or another statistical method. To solve a specific production problem and find ways to solve it, you can choose several different statistical methods, and their graphical representation will allow you to clearly see patterns that are difficult to distinguish in a simple table with a set of numbers. Plans may also be developed for the application of statistical methods of product quality management for a particular facility or quality indicator, implementation of which will allow the company to eventually understand whether the choice 
International Scientific and Practical Conference

ECONOMICS, POLITICS, LAW: TRENDS AND PROSPECTS

of statistical methods was carried out correctly and how appropriate their application is for the enterprise, which can lead to their correction in the future.

It is important that the introduction of statistical methods is aimed not only at identifying inappropriate products or processes, but also contributes to corrective actions aimed at improving product quality, streamlining production processes, increasing production efficiency and employee competence, as well as at maximum cost, maximizing the effect.

In order to demonstrate the advantages and ease of use of elementary statistical methods, we analyzed the quality of Borodino rye shaped bread of a piece weight of $0.8-1 \mathrm{~kg}$, which is produced in accordance with the requirements of GOST 2077-84 «Rye, rye-wheat and wheat-rye bread. Technical conditions "[1].

Today, for industrial enterprises, one of the most important tasks is to determine the factors that cause the process to deviate from the given requirements, as well as to eliminate their influence. In order to control the state of the bread manufacturing process over time and exposure to it before it can get out of control,you can useacce checklists. Control charts also serve as a data collection method for analyzing product quality. The main provisions for the application and interpretation of Shekhart control charts and related statistical process control methods are set in GOST R ISO 7870-2-2015 "Statistical methods. Control cards. Part 2. Shekhart control charts ", according to which, by the type of sample data used (or by the method of perceiving the quality criterion) control charts are divided into two classes -control charts for quantitative data: average and range $(\overline{\mathrm{X}}$ - and R-charts); average and standard deviations ( $\overline{\mathrm{X}}$-and S-cards); medians and ranges (M- and $\mathrm{R}$-cards); individual values and moving ranges ( $\mathrm{x}$ - and MR-cards)) and alternative data (shares of non-conforming units of production (p-card); number of non-conforming units of production in the sample (n-card); number of inconsistencies in the sample (s-card); the number of discrepancies per unit of production (u-card)) [2].

As a result of data collection at one of the enterprises of the food industry, we found that one of the types of marriage is a mismatch in the porosity of bread. In this regard, on the basis of statistical data we have built a ( $\overline{\mathrm{X}}-\mathrm{R})$-map in terms of "porosity" (Figure 1). This map is used to analyze and control processes whose quality indicators are continuous values and carry the greatest amount of information about the process [3]. 


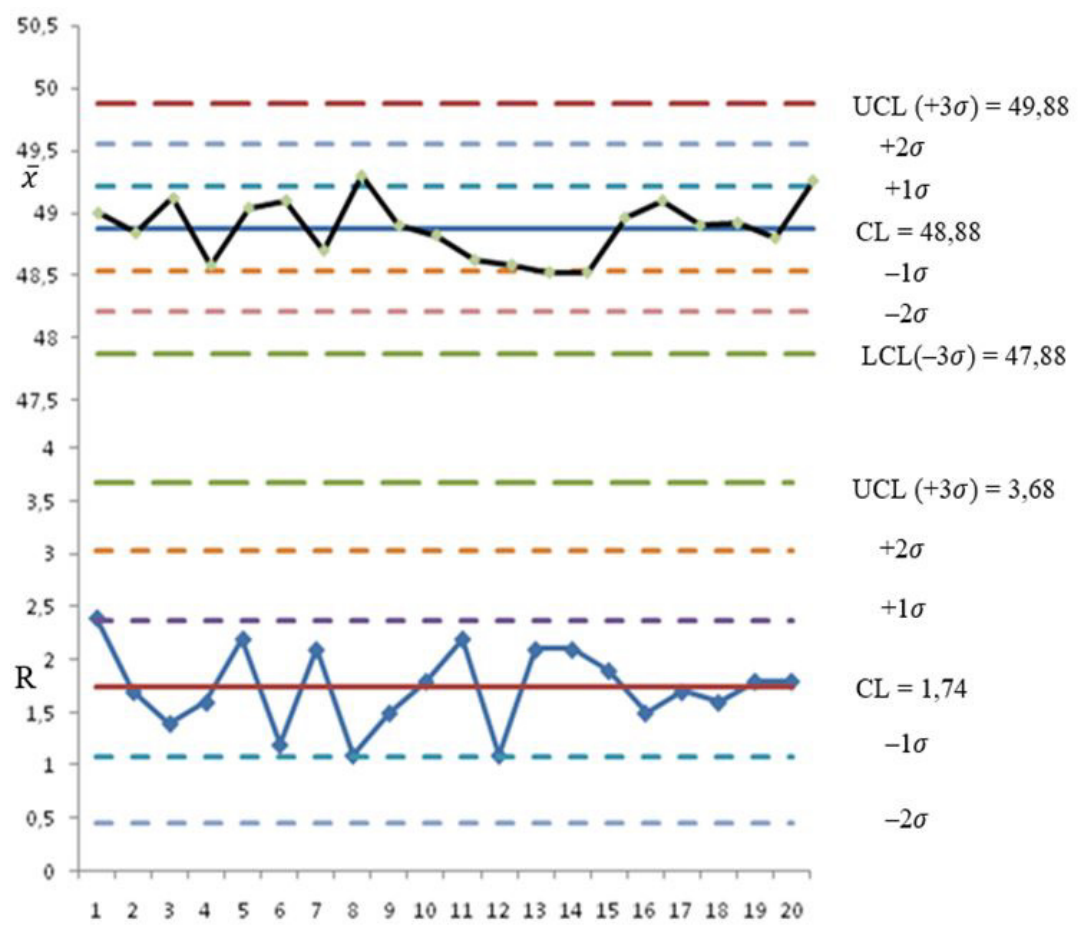

Figure 1. ( $\overline{\mathrm{x}}-\mathrm{R})$ - Map by "porosity" indicator.

Analysis of the control map showed the process instability. As evidenced by the presence of a «trend», the causes of which could be associated with a change in the composition of the raw materials, as well as low porosity could occur when using freshly ground flour and insufficient proofing of the dough. In this connection, it is necessary to provide the production process with raw materials of appropriate quality and strict observance by the personnel of the recipe. In addition, due to the collection in each sample of a certain number of measurements from different batches or the improvement in the process after calculating the control limits, the points are brought closer to the center line $(\mathrm{CL})$. In this case, the staff is recommended to evaluate the rationality of the volume of subgroups, to monitor compliance with the method of evaluating the porosity of bread.

We also conducted an analysis of the porosity of bread using a histogram (Figure 2), which allows you to visually assess the distribution of statistical data and determine the stability of the process, as well as find out the possible causes of the detected deviations from the set norms and develop corrective actions to improve the technological process and product quality. The decision on compliance is made on the basis of the analysis of the shape of the histogram, as well as its location relative to the technological tolerance. There are various types of histograms: indicating the stability of the process (ordinary type); process instabilities (a histogram extended to the right / left, a histogram in the form of a cliff, a two-hump histogram, a histogram in the form of a plateau, a histogram with gaps, a histogram with a separate island) [3, 4]. 


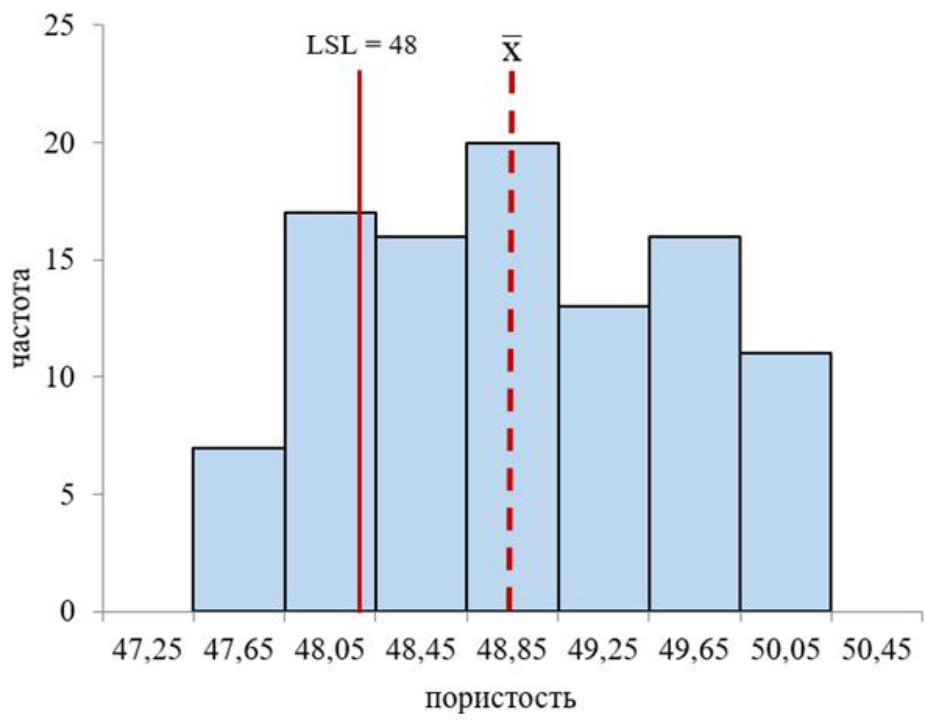

Figure 2. The histogram according to the "Porosity" indicator.

Figure 2 shows that the histogram has a shape with gaps due to the width of the interval, which is not a multiple of the unit of measurement, and there may also be an error made by the employee when calculating the "porosity" bread quality indicator according to the corresponding techniques. Due to the fact that the porosity of rye bread should be at least $48 \%$, then going beyond the lower tolerance limit indicates a marriage.

Thus, the manufacturer can control the quality of products and judge the state of the technological process by statistical data. Due to this, timely detect inconsistencies and take corrective actions, which will allow the processes to function in controlled conditions and guarantee the high quality of bakery products supplied to the consumer.

\section{References}

1. GOST 20077-84 Rye, rye-wheat and wheat-rye bread. Technical conditions - Introduced for the first time on 01.01.1986. - M: Standartinform, 2006 .- 6 p.

2. GOST R ISO 7870-2-2015 Statistical methods. Control cards. Part 2. Control cards of Shekhart. - Enter. 2016-12-01. - M .: Standartinform, 2016 .- 46 p.

3. Efimov, V.V. Statistical methods in product quality management / V.V. Efimov, T.V. Bart. - 2nd ed., Erased. - Moscow: KnoRus, 2013 .- 240 p.

5. Kume, H. Statistical Methods for Improving Quality: Translation from English / Ed. H. Kume. M.: Finance and Statistics, 1990. - 304 p.

5. Product Quality Management. Tools and methods of quality management / S. V. Ponomarev, S. V. Mishchenko, B. Ya. Belobragin, V. A. Samorodov, B. I. Gerasimov, A. V. Trofimov, C. A. Pakhomova, O. S. Ponomareva. - M.: RIA «Standards and Quality.»-2005. - 248 p. 
International Scientific and Practical Conference

ECONOMICS, POLITICS, LAW: TRENDS AND PROSPECTS

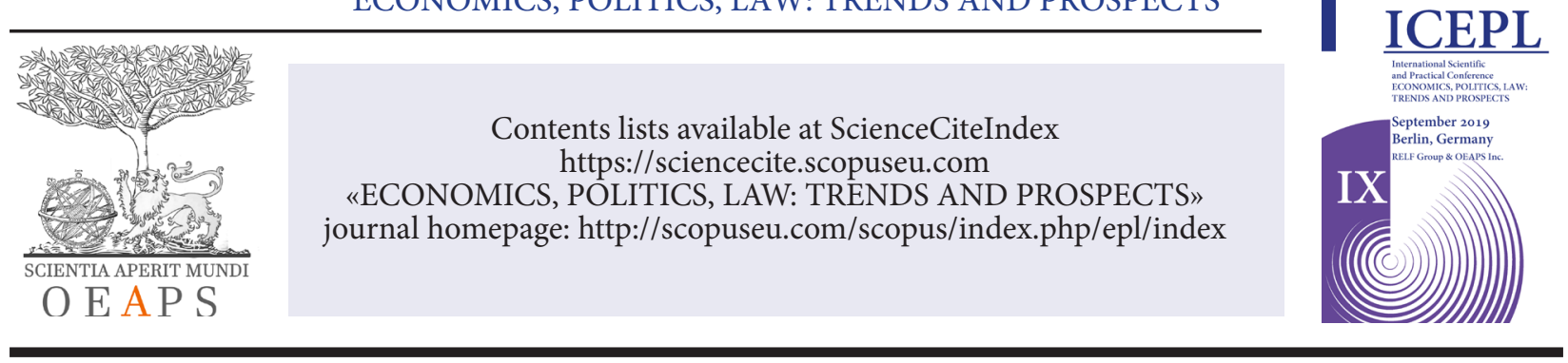

UDC 347.113

\title{
Problems of legal formalization and features of corporate obligations of members of socially-oriented NGOs
}

\author{
Kristina Igorevna Maiorova \\ Lawyer, Sawatzky Property Management \\ Independent Expert, Moscow, Russia \\ kristina.maiorova001@gmail.com
}

\begin{abstract}
The article discusses the problems of legal regulation of the corporate obligations of members of non-profit organizations that implement public interests. Based on an analysis, the author comes to a conclusion about the ineffectiveness of the norms of the Russian Civil code that fix unified obligations for members of both commercial and non-commercial organizations. Such norms contradict the particular principles of the functioning of socially-oriented NGOs, the most significant of which are enshrined in international acts and constitutional norms.
\end{abstract}

Key words: public organizations; corporate responsibilities; non-profit organizations; civil society; constitutional principles, socially-oriented NGOs

Corporate relations are an essential constituent of the system of membership (participation) relations in non-profit organizations registered as legal entities. Determination of their features and content will allow us to assess the effectiveness of civil law regulation norms that regulate this category of relations. During the reform of civil legislation, the general corporate responsibilities of participants of any corporations, regardless of the purpose of their creation, were fixed in Cl.4, Art 65.2 of the Civil Code of the Russian Federation. The legislator, however, did not take into account that non-profit organizations are elements of civil society, in a democratic state, designed to fulfill a specific socio-economic purpose. The ability to achieve this goal directly depends on the constitutional principles that underlie the functioning of non-profit organizations, including - voluntary organization creation and participation in it; independence in carrying out activities; self-government, involving the formation of the internal structure of the organization directly by its

(c) 2019 The Author. Published by OEAPS Inc. This is an open access article under the CC BY-NC-ND license (http://creativecommons.org/licenses/by-nc-nd/4.0/) 
International Scientific and Practical Conference

ECONOMICS, POLITICS, LAW: TRENDS AND PROSPECTS

participants. The preservation of these principles should be ensured in the case non-profit entities acquire the rights of a legal entity. In the process of updating the norms of civil legislation on legal entities, the noted circumstances were not taken into account.

The obligation list to be adhered to by members of corporate legal entities is opened by the obligation of members of the legal entity to participate in making corporate decisions which are critical for the organization in terms of continuing as going concern in accordance with the laws applicable, should their participation be necessary for the adoption of the above decisions (Para.4, Cl.4, Art.65.2 of the Civil Code of the Russian Federation). Corporate decisions, in particular, include those on the appointment of a sole executive body or members of the board of directors; on amendments to the articles of association or charter, if required by law, and no such decision made, a corporation is unable to continue as a going concern[12]. In some cases, this duty can be fully implemented by members of non-profit organizations. For instance, general meetings of a consumer cooperative address the issues of the creation of its assets, including the amount and procedure for making share contributions which are paramount for the functioning of the cooperative. In this case, a member of the organization is obliged to participate in the corporate decision-making on the contributions to the legal entity's assets, otherwise it will be unable to carry out statutory activities ${ }^{1}$.

However, in some cases the provisions of Para.4, Cl.4, Art. 65.2 of the Civil Code of the Russian Federation should be recognized as contradicting the constitutional framework of non-profit organizations, in particular, public ones. The principles they adhere to are self-government, internal corporate democracy. Such organizations may independently determine in their internal documents the ways and procedure for managing their activities, as well as the relevant rights and obligations of their members. So, the Charter of the All-Russian Public Organization "Sotsialnoe Sodeistvie"[17] establishes that voting at general meetings, along with bringing issues concerning corporate operations before the decision-making bodies, is a right rather than a duty of members (cl. 6.3). This condition corresponds to Art. 20 of the Law on Social Associations which holds that the rights and duties of members are defined by the organization's charter. However, the Civil Code of the Russian Federation contains no guidance on the priority of these norms over those of the Civil Code of the Russian Federation. Consequently, the provisions of the association's charter should be recognized as contrary to the civil law. At the same time, the public legal status and constitutional principles of the functioning of public organizations are paramount and should determine the content of the Russian Civil Code norms regulating the activities of such organizations, and not vice versa. In this regard, Para. 4, Cl. 4, Art. 65.2 of the Civil Code of the Russian Federation should hold that a corporate member is obliged to participate in the adoption of corporate decisions critical for the corporation as a going concern when his participation is necessary for the adoption of such decisions unless otherwise provided by law. Under some special laws on non-profit organizations

$1 \quad$ In this regard, it is necessary to bring the provisions of special laws on consumer cooperatives of certain types that recognize participation in voting on issues referred to the general meeting by right, not by obligation of members of the organization, into line with the civil code of the Russian Federation (see, for example, Art.13 of the Law on credit cooperation). 
of various forms, organizations are allowed to directly decide on the participation of members in corporate decision-making.

Para.3, Cl.4, Art. 65.2 of the Civil Code of the Russian Federation gives a very ambiguous definition of the member's obligation not to disclose any confidential information about corporate activities. To determine whether members of non-profit corporations are entitled to this obligation, it is necessary to identify the nature of confidential information in relation to the activities of such organizations. Currently, the concept of confidential information is not clearly disclosed at the regulatory level. According to Decree of the President of the Russian Federation of March 6, 1997, No.188 "On Approval of the Disclosure List", the confidential information is defined as being the data associated with commercial activities and limited by the Civil Code of the Russian Federation and Federal Law of July 29, 2004, No.98-Ф3 “On Trade Secrets" (commercial secret). Legal acts fail to define the concept of commercial activity. The literature indicates that commercial activities are part of the business activity in the commodity market and differ only in that they do not cover the process of providing services and manufacturing goods[11]. The fact that confidential information is formed in the course of business activity is evidenced by the understanding of trade secrets as a regime of confidentiality of information that allows its owner to increase revenues, avoid unnecessary costs, maintain the position in the market of goods, works, services or obtain other commercial benefits under any existing or possible circumstances (Art. 3 of the Law On Trade Secrets).

The current legislation deprives non-profit organizations of the right to engage in business activities. They are able to perform only the activities that generate income $(\mathrm{Cl}$. 5, Art. 50 of the Civil Code of the Russian Federation). The concept of income-generating activities is not disclosed at the legislative level ${ }^{2}$. The literature fails to offer any unified approach to understanding this category and its relationships with entrepreneurship[8]. For example, some authors point out that income-generating activities are essentially entrepreneurial activities carried out by nonprofit organizations[5]. Cl. 21 of Resolution of the Plenum of the Supreme Court of the Russian Federation of June 23, 2015, No. 25, indicates a similar nature of the categories in question. As per the Resolution, the legal provisions applicable to persons engaged in entrepreneurial activities apply to the non-profit organization in terms of its implementation of income-generating activities.

However, the opinion that the concept of income-generating activities is broader than that of entrepreneurial activities seems to be more reasonable, since one-time, non-systematic income, as well as the "income from assets received in the form of collateral or deposit as security for obligations, property contributions, in the form of property received within the framework of targeted financing, property (including cash) received under loan agreements...etc.'[7, P.52] can

$2 \quad$ Some authors point to the possibility of replacing the concept of entrepreneurial activities of non-profit organizations with the term "income-generating activities" or another similar term only after the revision of the legislation governing the conditions and limits of participation of such organizations in civil law relations. See, for example, Meniaev, A.V. The Legal Status and System of Non-Profit Organizations in the Russian Civil Law: Autoabstract, thesis research... Cand Sc. Law. Volgograd, 2011. P.10. 
International Scientific and Practical Conference

ECONOMICS, POLITICS, LAW: TRENDS AND PROSPECTS

be treated as the income not associated with entrepreneurial activities[10, P.18]. This is confirmed in Art. 26 of the Law On Non-Profit Organizations which recognizes not only the proceeds from the sale of goods, work, services as sources of creation of corporate assets, but also the dividends received on securities and deposits, as well as the income received from the assets of a non-profit organization.

Cl. 2, Art. 32 of the Law On Non-Profit Organizations stipulates that the size and structure of income of a non-profit organization, as well as the information about the size and composition of the assets of a non-profit organization, its expenses, as well as the information about the number and composition of employees, their remuneration, the use of gratuitous labor of citizens, cannot be deemed a subject of trade secrets. Please note that this statutory provision employs the concept of trade secret, not of confidential information. The list of data which make up a subject of trade secret is not fixed, and the data which do not make up its subject include the information not only connected with the implementation of income-generating activities by non-profit organizations (the size and structure of income), but also shaped with the aid of a legal entity in civil turnover as a whole (the data on the sizes and structure of corporate assets), along with information in the sphere of the labor relations (the data on the headcount and structure of employees, etc.). The concept of confidential information is not fixed in the Law On Non-Profit Organizations at all, so its relationship with the concept of trade secret remains unclear. Art. 28 of the Law On Agricultural Cooperation specifies the need to protect the confidentiality of the information constituting commercial and official secrets. The content of these concepts is not disclosed, either. As a result, it remains unclear what kind of information is a trade secret, what kind is an official secret, and how it relates to confidential information within the meaning of the Civil Code of the Russian Federation.

As the concept of confidential information is not fixed in the Civil Code of the Russian Federation, questions arise, firstly, about the relations between confidential information and trade secrets, and, secondly, about the framework of relations in which it arises in terms of the activities of non-profit organizations: a) in the implementation of activities for the sale of goods, work, services, which is an element of income-generating activities; b) in the implementation of any income-generating activities; c) in connection with running a non-profit Corporation as a participant in civil turnover as a whole; d) information arising in other areas of non-profit organizations (official, etc.).

In our opinion, the information which, if not disclosed, will allow a non-profit organization to retain its position in the market of goods, work, services or to enjoy other commercial benefits, cannot constitute the subject of trade secret within the meaning of the Law On Trade Secrets because such organizations are established not for making profit. However, this information may certainly include the information that will increase the income of a non-profit organization (in the implementation of income-generating activities) and allow avoiding unnecessary expenses.

Confidential information is a broad concept to include both the information constituting a trade secret and other information arising in the process of achieving the statutory goals of a non-profit 
organization. The confidential information of a non-profit organization can be defined as the information about the corporate activities whose disclosure may impede the achievement of its statutory goals valuable to the community. At the same time, it is necessary to tell the confidential information arising in the course of the activities of non-profit corporations as legal entities, the preservation of which will ensure their proper functioning, from the confidential information arising in the course of achieving social benefits by corporations as public associations. Such information can be constituted, for example, by any data of a political nature, as well as the data about the means and methods of influencing public views, special methods of achieving socially useful goals. In this regard, the obligation of corporate members to preserve the confidentiality of the information arising in the implementation of socially useful activities by organizations as public associations within the framework of relations of a different civil nature (for instance, in public law). The scope of such information and the confidentiality mode should be determined by the charter of a non-profit organization, considering the principle of openness of information and transparency of business.

It is necessary to fix in Para. 3, Cl. 4, Art. 65.2 of the Civil Code of the Russian Federation that corporate members are obliged not to disclose information on any activities of the legal entity unless otherwise provided for by law. In this regard, it is advisable to word Cl. 2, Art. 32 of the Law On Non-Profit Organizations as follows: "Confidential information can neither be constituted by the information on the size and structure of income of a non-profit organization, nor the information on the size and composition of assets of a non-profit organization, its expenses, the headcount and structure of employees, their wages, the use of gratuitous labor of citizens in the activities of a nonprofit organization".

Para. 6, Cl. 4, Art. 65.2 of the Civil Code of the Russian Federation establishes that members of any corporation are entitled to refrain from performing any actions (omissions) which essentially complicate the achievement of the purposes it was founded for or make it impossible. In commercial organizations, this obligation is implemented in full. The main activities of non-profit organizations go beyond the civil law framework. Trampling the authority of a political party by its member by way of making any public statements contradicting the purposes of the party's activities should not be deemed as a violation of the member's corporate obligations[15]. The same is true when a member of a Cossack association commits any acts of indecency which undermines the reputation of the association[16]. In the above cases, the actions (omissions) prevent the corporation as a social association from achieving the statutory public law purposes. Such violations can entail both nonproperty (reputational) and property damage. As a result of distributing any damaging information by members (participant) of a public organization, the latter can lose donations as one of the sources of shaping its assets. Despite the fact that the legal entity suffers from property damage, the violated obligation can still not be recognized as a corporate one, as it must be implemented in the public sphere within the framework of statutory activities performed by the public association. Perhaps, the obligation in question should be extended only to members of commercial organizations. Members of non-profit legal entities and, first of all, public organizations must comply with it only in the cases provided for by law. 
Para. 5, Cl. 4, Art. 65.2 of the Civil Code of the Russian Federation establishes the obligation of corporate members to refrain from performing any actions deliberately aimed at causing harm to the corporation. The corporate nature of this obligation and the need for being enshrined in the law are questionable. Some authors point out that the actions deliberately aimed at causing harm to the corporation should be understood as an abuse of member rights (Art. 10 of the Civil Code of the Russian Federation)[3]. In our opinion, there are no legal grounds for recognizing the obligation of members of a legal entity not to perform any actions deliberately aimed at causing harm to it, as the corporate one. As rightly stated in the literature, "the obligation to refrain from causing harm (or, what amounts to the same thing, not to perform any actions aimed at causing harm to other persons) is a general civil duty, which, if violated, entails the obligation arising from the fact of causing harm by virtue of the general tort structure (Chapter 59 of the Civil Code of the Russian Federation)"'[6, P.110]. Also, based on the literal understanding of Para. 5, Cl. 4, Art. 65.2 of the Civil Code of the Russian Federation, it turns out that any actions of the member aimed at causing harm to the corporation are recognized as a corporate obligation violation. However, the person whose actions are aimed at causing harm to the corporation does not always act as a member of the legal entity, for example, in the case of damaging its property. Such illegal actions cannot be recognized as a corporate obligation violation. In addition, the fact that these actions have been taken does not mean that the corporation has been harmed. In this case, the question arises as to the possible negative consequences for the member, since the obligatory condition for the occurrence of civil liability is the existence of the offence to which the harm is an element. Currently, there are no grounds sufficient enough for enshrining the obligation in Cl. 4, Art. 65.2 of the Civil Code of the Russian Federation.

Special attention should be paid to the duty of members of non-profit organizations to form their assets. In accordance with the Para. 2, Cl. 4, Art. 65.2 of the Civil Code of the Russian Federation, a corporate member is obliged to participate in the creation of its assets in the necessary size in the manner and terms provided for by the Civil Code of the Russian Federation, other law, or constituent documents of the organization. That is, members finance the activities of a legal entity by transferring their property thereto or giving it property rights. In relation to commercial legal entities, this obligation is fully implemented by members as stipulated by the Civil Code of the Russian Federation. In non-profit organizations, the obligation to form assets may not exist at all.

The analysis of Para. 2, Cl. 4, Art. 65.2 of the Civil Code of the Russian Federation shows that, on the one hand, persons that are included in any corporation should always participate in the creation of its assets, while the special norms of the Civil Code of the Russian Federation on legal entities of different forms, as well as laws and statutes should only determine the procedure and other organizational issues related to the implementation of this obligation. In this case, the mandatory establishment of the obligation of members to form the assets of a legal entity, regardless of the purposes of its creation and activities, may be due to the fact that the existence of separate assets is an attribute of a participant in the relations incorporated in the subject of civil law as per Art. 2 of the Civil Code of the Russian Federation. In this case, the non-profit organization should be 
considered only as a participant of economic activities which needs to have the assets to participate in civil turnover, including the performance of the obligations, assumed and in case civil liability is of relevance in case of their violation[1]. However, the acquisition by a non-profit organization of the legal entity rights may be due solely to the desire to expand the scope of legal opportunities in the public sphere. Members of a corporation transfer their assets thereto not to reduce the risk of their property losses in the course of the corporate activities aimed at profit-making, but to ensure the public association's activities to achieve social benefits. The doctrine also establishes that separate assets owned by an organization should be irrelevant to recognizing it a subject of law. These assets are of relevance only in the context of implementing income-generating activities, while the statutory objectives can be achieved in the absence of such assets[4, P.136]. In addition, it is stated that the asset-related isolation of a non-profit organization lies in its ability to have any assets so far as it goes, but such an organization, endowed for some period of time with civil legal personality, may in fact have no assets at all[2].

Therefore, it is possible to follow a different understanding of the obligation to create assets of a non-profit corporation: a member of a legal entity is obliged to participate in the creation of its assets only in cases provided for by law, in the manner and amount determined by special laws or constituent documents of the organization. This approach is confirmed in Cl. 2, Art. 123.7-1 of the Civil Code of the Russian Federation, whereby the provisions of the Civil Code of the Russian Federation on non-profit organizations are applied to public movements unless otherwise provided for by the Law On Public Associations. In accordance with Art. 31 of this Law, paying entrance and membership fees, out of which the assets of associations are formed, can (but not shall) be enshrined in the charter. With regard to indigenous communities, Cl. 4 of Art. 123.16 establishes a similar reservation as to the application of the Civil Code provisions only in the above cases unless otherwise provided for by a special law. However, Art. 13 of the Law "On Indigenous Communities" does not provide for the direct obligation of community members to create any community assets.

Some authors believe that "if a non-profit organization does not bear any costs in favor of its members, performs its activities without pursuing the goal of meeting their property needs, does not perform any public functions (bars, chambers of commerce), does not have the status of a self-regulatory organization, it is not entitled to collect any compulsory contributions from its members." $[9$, P.12] In support of his position, the author cites an example from judicial practice, when the Russian Defence Sports and Techniques Organization has veiled the paid provision of services by membership relations, and the fee paid for the services rendered, by membership fees[13].

We believe this opinion not to be sufficiently substantiated. In accordance with Cl. 5, Art. 50 of the Civil Code of the Russian Federation, should the charter of a non-commercial legal entity enshrine the possibility of any income-generating activity, such an organization should have assets in the amount of not less than the minimum size of the charter capital limited liability companies 
International Scientific and Practical Conference

ECONOMICS, POLITICS, LAW: TRENDS AND PROSPECTS

are to have. Therefore, the members of a corporation planning to perform such activities should be obliged to create corporate assets. Otherwise, due to the irregularity and insufficiency of donations and other voluntary contributions, a non-profit organization may be deprived of the opportunity to engage in income-generating activities, as a result of which it will fail to achieve its statutory socially useful goals. It should be noted that the charters of even those organizations which are legally free to choose their sources of asset creation (for example, public organizations) usually enshrine the obligation of its members to make corporate contributions. For example, the activities of the leading political parties in various Russian regions necessitate income-generating operations, which implies the existence of the charter capital. In this regard, the internal documents of the parties, as a rule, enshrine the corporate obligation of their members to make corporate contributions which are a stable source of asset creation[14].

The analysis of the special provisions of the Civil Code of the Russian Federation on non-profit legal entities and the laws on non-profit organizations of certain legal forms leads to the conclusion that the provisions of Para. 2, Cl. 4, Art. 65.2 of the Civil Code of the Russian Federation are of no relevance. Thus, Art.123.11 of the Civil Code of the Russian Federation expressly provides that members of an association (union) are obliged not only to comply with the requirements of $\mathrm{Cl}$. 4, Art. 65.2 of the Civil Code, but also to make the membership contributions to corporate assets provided for by the charter, and, if so decided by the supreme body, additional contributions. The fact is ignored that no participation of members of certain types of associations (unions), pursuing public goals, in the creation of their assets is expected. For example, the issue of the sources of asset creation employed by trade unions is resolved in the trade union's charter (Art. 7 of the Law On Trade Unions). A similar legislative approach is envisaged for employers' associations. The obligation of their members to make contributions to the corporate assets is not regulated (Art. 8, 11 of the Law On Employers' Associations).

In accordance with $\mathrm{Cl} .2$, Art. 123.6 of the Civil Code of the Russian Federation, members (participants) of public organizations, along with the performance of the duties provided for by Cl. 4, Art. 65.2 of the Civil Code of the Russian Federation, are obliged to pay the membership and other property contributions provided for by the charter of the organization. In accordance with Art. 123.7 of the Civil Code of the Russian Federation, the supreme managing body of a public organization does not decide on the need for its members to make any membership and other property contributions in general. Its exclusive competence is only to determine the amount of contributions and the procedure for their payment. Therefore, the obligation of the members of a public organization to finance its activities is presumed, and it is only the determination of the amount and procedure for making contributions that falls within the competence of its bodies. The above provisions fail to reflect the essence of public organizations, which, in the implementation of the statutory activities, act rather as public associations than legal entities.

With regard to public organizations and associations (unions), the Civil Code of the Russian Federation fails to provide for the priority of special laws over the provisions of the Civil Code 
of the Russian Federation. In accordance with Cl. 4, Art. 3 of Federal Law of May 5, 2014, No. 99-Ф3 On Amendments to Art. 4, Part 1 of the Civil Code of the Russian Federation and on the Invalidation of Certain Provisions of Legislative Acts of the Russian Federation, before bringing any legislative and other regulatory legal acts in accordance with the provisions of the Civil Code of the Russian Federation, the provisions of such acts apply insofar as they do not contradict the provisions of the Civil Code of the Russian Federation. Consequently, the reference made in the Law On Public Associations and the laws on associations (unions) of certain types to the voluntary nature of membership and other corporate contributions, in fact, contradicts the Civil Code of the Russian Federation which fails to consider that non-profit organizations follow the principles of selfgovernment and self-control in their activities. Such organizations may choose their own sources to fund their activities. There may be no need for making any contributions by their members at all. Having established the obligation of members of any corporation to participate in the creation of its assets, the Civil Code of the Russian Federation went beyond the regulation of the civil status of non-profit organizations. To eliminate the contradictions, it is necessary to amend a number of special provisions of the Civil Code of the Russian Federation concerning non-profit organizations. Cl. 2, Art. 123.6 should be amended to include the provision that members of a public organization shall be involved in the creation of corporate assets unless otherwise provided for by law. The similar wording shall be enshrined in Cl. 2, Art. 123.11 of the Civil Code of the Russian Federation in relation to members of associations (unions).

In conclusion, the imposition on participants of both commercial and non-commercial legal entities and, above all, public organizations, of general corporate responsibilities is unreasonable. The formation of the provisions of $\mathrm{Cl}$. 4 of Art. 65.2 of the Civil Code of the Russian Federation was carried out on the basis of an analysis of corporate relations in commercial organizations. The legislator did not take into account constitutional principles of non-profit organizations that determine the specifics of their status, the heterogeneous composition of their members (participants). Therefore, not all corporate obligations of members of a legal entity, enshrined in Art. 65.2 of the Civil Code of the Russian Federation, can be effectively implemented in non-profit organizations. This circumstance complicates law-enforcement activity and causes difficulties in qualifying by courts the nature of the relationship between a legal entity and its members. This problem can be eliminated by amending certain norms of the Civil Code of the Russian Federation, taking into account the constitutional status of a number of non-profit organizations and, above all, public ones.

\section{References}

1. Avilov, G.E., Sukhanov, E.A. Legal Entities in the Modern Russian Civil Law// Bulletin of Civil Law. 2006. No. 1/Consultant Plus Legal Reference System.

2. Barkov, A.V. Civil Capacity of the Public Association of Disabled Persons: Autoabstract, thesis research... Cand Sc. Law. Moscow, 2002.

3. Comments to the Civil Code of the Russian Federation (Educational and Practical)/ Ed. by Stepanov, S.A. - Edition 5 - M.: Prospekt, 2015/ Consultant Plus Legal Reference System. 
International Scientific and Practical Conference

ECONOMICS, POLITICS, LAW: TRENDS AND PROSPECTS

4. Greshnikov, I.P. Subjects of Civil Law: Legal Entity in Law and Legislation. Spb.: Press Law Center, 2002. P. 136-137.

5. Grosul, Iu.V. On the Right of Non-Profit Organizations to Engage in Entrepreneurial Activities // Business Law. Supplement "Business and Law in Russia and Abroad." 2013. No. 3// Consultant Plus Legal Reference System.

6. Gutnikov, O.V. Expelling a Member from a Legal Entity: the Measure of Responsibility and the Method of Corporate Right Protection // The Bulletin of Economic Justice of the Russian Federation. 2015. No. 2. P. 110.

7. Zvezdina, T. M. Revisiting the Relations between the Concepts of Entrepreneurial and Income-Generating Activities of Non-Profit Organizations// Business, Management and Law. 2014. No. 2. P.75; Tarasenko, O.A. Entrepreneurial activities of Subjects of the Russian Banking System. M.: Prospekt, 2015. P. 52-53.

8. Iershova, I.V. Economic Activities: Concept and Relations with Adjacent Categories// Lexrussica. 2016.N 9// Consultant Plus Legal Reference System.

9. Nestolii, V. The Chaos of Non-Profit Organizations // EZh-Lawyer. 2011. No. 14. P. 12.

10. Tarasenko, O.A. On Entrepreneurial and Income-Generating Activities of Non-Profit Organizations// Lawyer. 2014. No. 23. P. 18.

11. Tretiak, S. N. Commercial Activities. Part I. Fundamentals of Theory and Organization. Khabarovsk: Published by the Far Eastern State Transport University, 1999. Quoted after: http:// www.aup.ru/books/m164/3_1.htm.

12. Cl. 34 of Resolution of the Plenum of the Supreme Court of the Russian Federation of June 23, 2015, No. 25 "On Court Application of Certain Provisions of Section 1, Part 1 of the Civil Code of the Russian Federation"// Rossiyskaya Gazeta. 2015. No. 140.

13. Resolution of the Federal Arbitration Court for the Ural District of December 15, 2009, No. F09-9894/09-C3 in Case No. A71-3736/2009A19// Consultant Plus Legal Reference System. 14. Art. 2 of the Charter of the Communist Party of the Russian Federation Political Party// URL: https://kprf.ru/party/charter.; Art.9 of the Charter of the YABLOKO Russian United Democratic Party Political Party// URL: http://www.yabloko.ru/Union/ustav.html; Art.7 of the LDPR Charter. 15. Cl. 4.9 of the LDPR (Liberal Democratic Party of Russia) Charter // URL: http://ldpr.ru/ party/ustav/. Hereinafter, the LDPR Charter.

16. Cl. 4.8 of the Bogorodskoe Rural Cossack Association // URL: http://moskazak.ucoz.ru/ publ/ustav_bogorodskoe/1-1-0-2ю.

17. The official website of the All-Russian Public Organization "Sotsialnoe Sodeistvie"// URL http://socialife.ru/about/charter/. 
International Scientific and Practical Conference

ECONOMICS, POLITICS, LAW: TRENDS AND PROSPECTS

Contents lists available at ScienceCiteIndex https://sciencecite.scopuseu.com «ECONOMICS, POLITICS, LAW: TRENDS AND PROSPECTS»

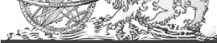
SCIENTIA APERIT MUN journal homepage: http://scopuseu.com/scopus/index.php/epl/index

O E AP S

\section{УДК 343.233}

\section{Понятие причинения вреда при задержании лица, совершившего преступление}

Котельвин Максим Олегович

Преподаватель кафедры специиальных дисичилин

Владивостокского филиала Федерального государственного казенного образовательного

учреждения высшего образования Дальневосточный юридический институт МВД России, Россия, г. Владивосток Maxikot125@mail.ru

Кожевникова Оксана Николаевна

Стариий преподаватель кафедры специальных дисииплин Владивостокского филиала Федерального государственного казенного образовательного учреждения высшего образования Дальневосточный юридический институт МВД России, Россия, г. Владивосток ksanak1012@mail.ru

The concept of harm during the detention of the person who committed the crime

Kotelvin Maxim Olegovich Lecturer, Department of Special Disciplines Vladivostok branch of the Federal State Treasury Educational Institution of Higher Education Far Eastern Law Institute of the Ministry of Internal Affairs of Russia, Russia, Vladivostok

\section{Kozhevnikova Oksana Nikolaevna}

Senior Lecturer, Department of Special Disciplines Vladivostok branch of the Federal State Treasury Educational Institution of Higher Education Far Eastern Law Institute of the Ministry of Internal Affairs of Russia,

Russia, Vladivostok

(C) 2019 The Author. Published by OEAPS Inc. This is an open access article under the CC BY-NC-ND license (http://creativecommons.org/licenses/by-nc-nd/4.0/) 
International Scientific and Practical Conference

ECONOMICS, POLITICS, LAW: TRENDS AND PROSPECTS

Аннотация: В статье проанализировано такое уголовно-правовое понятие, как причинение вреда при задержании лица, совершившего преступление, рассмотрены различные точки зрения на данное явление.

Ключевые слова: преступление; преступник; причинение вреда; задержание; уголовная ответственность.

Abstract: The article analyzes such a criminal law concept as causing harm during the detention of the person who committed the crime, considers various points of view on this phenomenon.

Keywords: crime; criminal; harm; detention; criminal liability.

Для того чтобы раскрыть сущность определенного явления, необходимо ясно и лаконично выделить характерные для него признаки, черты, т.е. дать ему определение.

Уголовно-правовая дефиниция «причинение вреда при задержании лица, совершившего преступление» возникла в отечественном уголовном законодательстве лишь в 1996 году, с принятием ныне действующего УК РФ, в состав которого законодатель включил ст. 38 с соответствующим названием. Данная статья структурно размещена в главе восьмой УК РФ, среди норм определяющих обстоятельства, исключающие преступность деяния.

Что касается уголовно-правовой доктрины, то здесь имеет место плюрализм и дискуссионность мнений относительно изучаемого нами понятия. Учеными до сих пор не выработан общий подход относительно содержания дефиниции данного явления и характеристике ее признаков.

Например, И.Г. Плэмэдялэ определяет задержание преступника как обеспечиваемый государством, основанный на управомочивающих нормах уголовно-правового характера способ общественно полезного, правомерного поведения. Указанный правомерный характер, соответственно, исключает какую-либо ответственность лица, за вред, причинённый преступнику при его задержании [9, с. 18]. Здесь мы можем видеть, что автор исключает любого рода юридическую ответственность, в том числе, например, дисциплинарную или гражданско-правовую.

Заявленную позицию разделяет также М.М. Пронина [11, с. 16].

Несколько отличное мнение высказывает И.Р. Сичинава, который пишет, что не может рассматриваться как преступление, хотя и содержащее внешне его признаки, вынужденное причинение вреда, совершенное в процессе задержания преступника. При этом автор обращает внимание на соразмерность причиняемого вреда общественной опасности совершённого деяния и отсутствие иной возможности, иного способа осуществить задержание преступника [13, с. 13]. 
С.А. Якунина рассматривает уголовно-правовую сущность изучаемой нами категории в качестве кратковременного ограничения свободы лица, совершившего уголовно-наказуемое деяние, посредством правомерного причинения силового воздействия, сопровождаемого причинением вреда. Социальная значимость и правомерность таких действий обусловлена необходимостью передать преступника в руки органов, осуществляющих предварительное расследование и пресечь возможность совершения им новых преступлений в дальнейшем $[15$, с. 15$]$.

Отметим, что выделение автором такого признака как кратковременность характера задержания, носит спорный характер, поскольку данное действие может быть осуществлено в условиях удаленности от населенных пунктов, отсутствия средств коммуникации и т.д. (например, на судне, находящемся в открытом море или удаленной полярной станции), когда, ограничение свободы задержанного лица может оказаться достаточно длительным.

А.В. Никуленко высказывает мнение, что правомерным и социально оправданным может рассматриваться причинение вреда лишь в случае оказания задерживаемым лицом активного сопротивления его доставлению в органы власти [7, с. 119].

Безусловно, принцип минимизации вреда при задержании имеет важное, в том числе, уголовно-правовое значение. Однако, позиция автора, акцентирующего внимание на активной форме сопротивления преступника, представляется сомнительной. Оказание преступником пассивного сопротивления вовсе не исключает необходимость его задержания, в том числе, и с применением соразмерного его сопротивлению физического воздействия, посредством которого может быть причинен вред.

Также отдельными специалистами в литературе высказывается мнение что меры уголовно-правового задержания по сути сопряжены с такой степенью причинения вреда, которая необходима для поимки, пытающегося скрыться с места происшествия преступника [6, с. 13].

В.В. Пономарь в рассматриваемом нами понятии видит совокупность элементов объективного и субъективного характера, которые обуславливают правомерный характер действий, совершаемых с целью задержания лица, совершившего преступление и доставления его в органы власти, связанные с причинением ему вреда, необходимого для реализации данной цели [10, с. 72].

Разногласия среди ученых относительно единого понимания в определении института причинения вреда при задержании говорит о проблематичности в установлении его юридической природы и социальной сущности. Очевидно, что этот уголовно-правовой институт еще находится в стадии своего становления. 
International Scientific and Practical Conference ECONOMICS, POLITICS, LAW: TRENDS AND PROSPECTS

Не вызывает споров то обстоятельство, что рассматриваемое нами правоотношение входит в систему обстоятельств, исключающих преступность деяния, и таким образом в значительной мере наделено общими признаками, присущими данной системе в целом.

А.П. Дмитренко справедливо считает, что все обстоятельства, исключающие преступность деяния, могут быть рассмотрены в двух аспектах. Во-первых, с точки зрения внешнего фактора, существующего определенный период времени вне зависимости от субъекта, действия которого подлежат юридической оценке. Во-вторых, эти обстоятельства включают в себя определенные действия субъекта $[1$, с. 36$]$.

Используя указанный методологический прием, причинения вреда при задержании лица, совершившего преступление, можно рассматривать как возникающее в объективной реальности правоотношение, в котором принимают участие лицо (лица), совершившее преступное деяние и лицо (лица), действия которых направлены на его (их) задержание. В рамках данного правоотношения, возникает юридическое дозволение причинить задерживаемому лицу вред (различного характера: имущественного, физического, морального), в пределах, необходимых для пресечения возможности преступника продолжить общественно опасные действия и передачи задержанного в органы государственной власти, уполномоченные на проведение предварительного расследования.

Перейдем теперь к характеристике юридических признаков исследуемого нами института, получивших освещение в научной литературе.

В литературе высказываются различные мнения относительно того в отношении какого лица может быть применено задержание, сопровождаемое возможным причинением вреда.

Есть мнение, что задержанию могут подвергнуться только вменяемые лица, достигшие возраста уголовной ответственности, т.е. субъекты преступления в строгом понимании [2, c. 44]. Данная концепция, несмотря на казалось бы, серьезную теоретическую обоснованность, представляется нереализуемой в практической ситуации. Например, для установления вменяемости лица, требуется длительное изучение его личности с привлечением специалистов-медиков. То есть гражданин, осуществляющий задержание преступника, в любом случае не может быть полностью уверен в его вменяемости. Также очевидно, что не всегда известен и точный возраст задерживаемого. Кроме того, уголовная ответственность за различные преступления может возникать с разного возраста, при этом окончательную квалификацию совершенному преступному деянию может дать только суд, но никак не гражданин, задерживающий преступника.

Другая точка зрения сводится к тому, что задержанию подлежит любое лицо, которое как очевидно ясно задерживающему совершило преступление [12, с. 38.]. 
International Scientific and Practical Conference

ECONOMICS, POLITICS, LAW: TRENDS AND PROSPECTS

Так, А.Г. Кибальник высказывает точку зрения, относительно того, что задержанию может быть подвергнуто любое лицо, совершившее действия, содержащие признаки преступления, в том числе, в случаях, когда имеются обоснованные предположения, что данное лицо попытается скрыть следы своей противозаконной деятельности или продолжить реализацию своих преступных замыслов [3, с. 28].

Интересна также мысль, высказанная И.М. Тяжковой относительно того, что под лицом, совершившим преступление в смысле ст. 38 УК РФ может пониматься также субъект, осужденный за его совершение, но по каким-либо причинам, избегающий исполнения наказания [14, с. 388$]$.

Наиболее критичная позиция по рассматриваемому нами вопросу изложена Н.Г. Кадниковым, который вообще считает формулировку ст. 38 УК РФ в части указания на задерживаемое лицо не соответствующей действующему законодательству [5, с. 114].

По нашему мнению, законодатель, используя формулировку «лицо, совершившим преступление», понимал под ней скорее лицо, правонарушителя, совершившего деяние, запрещённое уголовным законодательством, общественно опасный характер которого очевиден для окружающих.

Некоторую ясность в рассматриваемый нами вопрос вносят разьяснения Постановления Пленума Верховного Суда РФ от 27.09.2012 г. № 19 [8], где отмечается, что задерживающий должен быть уверен, что причиняет вред именно преступнику. В разъяснениях отмечается, что если задерживающий добросовестно заблуждался относительно противоправности (уголовной наказуемости) деяния, либо относительно возраста и вменяемости задерживаемого лица, то его действия должны все равно оцениваться по правилу ст. 38 УК РФ.

Аналогичным образом Пленум Верховного Суда рекомендует оценивать ситуации добросовестного заблуждения задерживающего относительно того кем именно было совершено преступление (п. 24).

Также не имеет значение удалось преступнику окончить свой замысел или нет (п. 20), вместе с тем недопустимо причинение в процессе задержания какого-либо вреда иным лицам (п. 25).

Таким образом, причинение вреда, указанное в ст. 38 УК РФ допускается в отношении любого лица, действия которого имеют признаки уголовно наказуемого деяния и не допустимо в отношении иных лиц.

Рассматриваемая нами норма устанавливает право любого лица, (а не только сотрудников правоохранительных органов) пресечь преступление и способствовать привлечению вино- 
International Scientific and Practical Conference ECONOMICS, POLITICS, LAW: TRENDS AND PROSPECTS

вного к уголовной ответственности [4, с. 56]. На этот социально значимый аспект прямо указывают и разъяснения вышеупомянутого Пленума Верховного Суда (п. 19).

Норма ст. 38 УК РФ не содержит ответа на вопрос, что включает в себя причинение вреда, имеется лишь указание, что оно не является преступлением. На наш взгляд формулировка «не является преступлением» не отражает всю общественную сущность характеризуемого нами уголовно-правового института, фактически равняя его с невиновным причинением вреда.

М.М. Пронина справедливо отмечает в этой связи, что содержащаяся в ст. 38 УК РФ формулировка не отражает истинную социальную сущность причинения вреда при задержании, создает неверное впечатление о его нейтральном значении для социума и государства [11, с. 19].

Безусловно, с точки зрения уголовного права интерес представляет деление деяний на преступные и непреступные, однако, в рассматриваемом нами случае, речь идет не просто о непреступном деянии, а о деянии, представляющем определенную пользу для общества, несмотря даже на то, что внешне оно сопровождается причинением вреда, т.е. имеет внешние признаки общественной опасности.

Таким образом, рассматриваемая нами категория диалектически характеризуется как общественно полезное деяние по содержанию и общественно вредная по внешнему выражению. Этот аспект имеет социальное значение, он обуславливает определенные последствия для преступника и задерживающего лица, всего общества в целом и государства.

В этой связи И.Г. Плэмэдялэ даже выносит предложение включить поощрительную норму в исследуемый нами уголовно-правовой институт [9, с. 20].

Однако, подчеркнем, что полезность рассматриваемого явления характеризует его содержательную сторону. Такие категории как «общественная полезность» и «общественная ценность» носят характер скорее не уголовно-правовой, а социально-этический. Объективно общество получает полезный результат борьбы с преступностью, который вместе с положительным примером социально активного поведения задерживающего лица имеет социальную ценность. В то же время, внешнее проявление действий задерживающего сопровождается причинением вреда задерживаемому, что не может оцениваться как социально полезный результат (например, преступник получает травмы, приводящие к его инвалидности). Поэтому наиболее объективной является оценка причинения вреда при задержании преступника ни как общественно полезное действие, а как допустимое для интересов общества. 
International Scientific and Practical Conference

ECONOMICS, POLITICS, LAW: TRENDS AND PROSPECTS

Вопрос о юридической оценке действий задерживающего лица имеет значение лишь в том случае, когда в результате таких действий причиняется ущерб охраняемым уголовным законом интересам. Речь, таким образом, идет о таком специфическом признаке уголовно-правового задержания, как правомерность причинения ущерба объектам уголовно-правовой охраны.

Нормы Особенной части УК РФ в этой связи предусматривают ответственность за умышленное причинение смерти (ч. 2 ст. 108 УК РФ) и тяжкого вреда или средней тяжести вреда здоровью (ч. 2 ст. 114 УК РФ), причиненные в результате превышения мер, допустимых при задержании преступника. Кроме того, в уголовном законе имеется норма п. «ж» ч. 1 ст. 61 УК РФ предусматривающая такое обстоятельство смягчающее наказание как нарушение условий правомерности задержания лица, совершившего преступление.

Следовательно, законодатель связывает социальную допустимость и юридическую правомерность нанесения вреда задерживаемому преступнику с четким соблюдением нормативно установленных условий и пределов правомерности, что, безусловно, необходимо выделить как важный признак изучаемого нами уголовно-правового института.

Важное уголовно-правовое значение имеет также время нанесения вреда. Правомерным, согласно смыслу ст. 38 УК РФ является только вред, причиненный в процессе задержания преступника. Следовательно, причинение какого-либо вреда лицу, прекратившему сопротивление (т.е. уже фактически задержанному) не будет попадать под действие правила ст. 38 УК РФ.

Также важное значение имеют цели причинения вреда, а именно: его задержание, пресечение преступных действий, доставление задержанного органам власти. Любая иная цель причинения вреда (например, месть, самосуд и т.п.) будет иметь противоправный характер.

Следует иметь в виду, что указанная в ст. 38 УК РФ возможность совершения преступником новых общественно опасных деяний отнюдь не подразумевает какую-либо известную закономерность в поведении задерживаемого. Речь идёт в широком смысле о любой степени вероятности повторения преступных посягательств в будущем.

Резюмируя вышеизложенные признаки, мы приходим к выводу о том, что причинение вреда при задержании лица, совершившего преступление, как обстоятельство, исключающее преступность деяния, следует рассматривать в качестве социально допустимого, юридически правомерного деяния, сопровождающегося причинением вреда объектам уголовно-правовой защиты, при наличии и соблюдении установленных уголовным законом условий, оснований и пределов. 
International Scientific and Practical Conference

ECONOMICS, POLITICS, LAW: TRENDS AND PROSPECTS

\section{Список литературы}

1. Дмитренко А.П. Обстоятельства, исключающие преступность деяния, в уголовном праве Российской Федерации: монография / А.П. Дмитренко. - М.: Илекса, 2010. - 344 с.

2. Иванов А.Б. Институт причинения вреда при задержании лица, совершившего преступление: учебное пособие / А.Б. Иванов. - М.: Проспект, 2014. - 188 с.

3. Кибальник А.Г. Обстоятельства, исключающие преступность деяния: монография / А.Г. Кибальник. - М.: Юрлитинформ, 2013. - 402 с.

4. Клюев А.А. Правомерность причинения вреда при задержании лица, совершившего преступление / А.А. Клюев // Российская юстиция. - 2015. - № 5. - С. 56-59.

5. Комментарий к Уголовному кодексу Российской Федерации / Под общ. ред. Н.Г. Кадникова. - М.: Норма, 2014. - 825 с.

6. Кондрашова О.В. Уголовно-правовая оценка причинения вреда при задержании лица, совершившего общественно опасное посягательство. / О.В. Кондрашова. - Тюмень: ТЮИ, 2004. -125 c.

7. Никуленко А.В. Актуальные проблемы правовой регламентации причинения вреда при задержании лица, совершившего общественно опасное деяние / А.В. Никуленко // Уголовному кодексу РФ 15 лет: достижения, проблемы, тенденции: сборник научных статей. - СПб.: СПбГУЭФ, 2012. - С. 118-127.

8. О применении судами законодательства о необходимой обороне и причинении вреда при задержании лица, совершившего преступление: постановление Пленума Верховного Суда РФ от 27.09.2012 г. № 19 // Российская газета. - № 227. - 2012.

9. Плэмэдялэ И.Г. Причинение вреда при задержании лица, совершившего преступление / И.Г. Плэмэдялэ. - М.: Проспект, 2017. - 126 с.

10. Пономарь В.В. Причинение вреда при задержании лица, совершившего преступление, как обстоятельство, исключающее преступность деяния: монография / В.В. Пономарь. - М.: АНО «Юридические программы», 2016. - 334 с.

11. Пронина М.М. Причинение вреда при задержании лица, совершившего преступление: уголовно-правовая регламентация и ее совершенствование / М.М. Пронина. - Челябинск: УРГЮА, 2015. - $127 \mathrm{c}$.

12. Рабаданов А.С. Необходимая оборона и причинение вреда при задержании лица, совершившего преступление: учебное пособие / А.С. Рабаданов. - Саратов: СЮИ, 2013. - 161 с.

13. Сичинава И.Р. Причинение вреда при задержании лица, совершившего преступление (уголовно-правовые аспекты) / И.Р. Сичинава. - Ростов-на-Дону: Феникс, 2014. - 124 с.

14. Уголовное право России. Общая часть: Учебник для вузов / Под ред. Н.Ф. Кузнецовой и И.М. Тяжковой. - М.: Норма, 2012. - 538 с.

15. Якунина С.А. Причинение вреда при задержании лица, совершившего преступление / С.А. Якунина. - Ростов-на-Дону: Феникс, 2015. - 126 с. 


\section{The text of the article in English}

In order to reveal the essence of a certain phenomenon, it is necessary to clearly and concisely identify its characteristic signs, features, i.e. give him a definition.

The criminal law definition "harming the detention of the person who committed the crime" did not appear in the domestic criminal law until 1996, with the adoption of the current Criminal Code of the Russian Federation, in which the legislator included art. 38 with the appropriate name. This article is structurally placed in Chapter Eight of the Criminal Code of the Russian Federation, among the norms defining circumstances that exclude criminal acts.

As for the criminal law doctrine, there is pluralism and debatable opinions regarding the concept we are studying. Scientists still have not developed a common approach regarding the content of the definition of this phenomenon and the characteristics of its features.

For example, I.G. Plamediale defines the arrest of a criminal as being provided by the state, based on competent criminal law standards, as a way of socially useful, lawful behavior. The indicated lawful nature, accordingly, excludes any liability of the person for harm caused to the criminal during his detention $[9$, p. 18]. Here we can see that the author excludes any kind of legal liability, including, for example, disciplinary or civil law.

The stated position is also shared by M.M. Pronin [11, p. sixteen].

A somewhat different opinion is expressed by I.R. Sichinava, who writes that he cannot be regarded as a crime, although containing outwardly his signs, is an involuntary infliction of harm committed in the process of apprehending a criminal. At the same time, the author draws attention to the proportionality of the harm caused to the public danger of the committed act and the absence of any other possibility or other way to detain the criminal [13, p. 13].

S.A. Yakunina considers the criminal law essence of the category we are studying as a short-term restriction on the freedom of the person who committed the criminal offense, by lawfully causing forceful effects, accompanied by harm. The social significance and legitimacy of such actions is due to the need to transfer the criminal to the hands of the bodies conducting the preliminary investigation and to stop the possibility of new crimes in the future [15, p. 15].

It should be noted that the author's identification of such a sign as the short duration of the nature of the detention is controversial, since this action can be carried out in conditions of remoteness from settlements, lack of means of communication, etc. (for example, on a ship located on the high seas or at a remote polar station), when, the restriction on the freedom of a detained person can be quite long. 
International Scientific and Practical Conference

ECONOMICS, POLITICS, LAW: TRENDS AND PROSPECTS

A.V. Nikulenko expresses the opinion that harm can be considered legitimate and socially justified only if the detained person actively resistes his delivery to the authorities [7, p. 119].

Of course, the principle of minimizing harm during detention is important, including criminal law. However, the position of the author, focusing on the active form of resistance of the offender, seems doubtful. Providing the criminal with passive resistance does not at all preclude the need for his detention, including using a physical effect commensurate with his resistance, through which harm can be caused.

Also, some experts in the literature are of the opinion that the measures of criminal law detention in fact are associated with such a degree of harm that is necessary for the capture, trying to escape from the scene of the offender [6, p. 13].

V.V. The sexton in the concept we are considering sees a combination of elements of an objective and subjective nature that determine the lawful nature of the actions taken to detain a person who committed a crime and bring him to the authorities, connected with causing him harm necessary to achieve this goal [10, p. 72].

Disagreements among scientists regarding a common understanding in determining the institution of harm during detention indicate a problem in establishing its legal nature and social nature. Obviously, this criminal law institution is still in its infancy.

The fact that the relationship under consideration is part of a system of circumstances that exclude the crime of an act, and thus is largely endowed with general features inherent in this system as a whole, does not cause disputes.

A.P. Dmitrenko rightly believes that all circumstances excluding the crime of an act can be considered in two aspects. Firstly, from the point of view of an external factor that exists for a certain period of time, regardless of the subject, whose actions are subject to legal assessment. Secondly, these circumstances include certain actions of the subject [1, p. 36].

Using the indicated methodological method, harm during the detention of the person who committed the crime can be considered as a legal relationship arising in objective reality, in which the person (s) who committed the criminal act and the person (s) whose actions are aimed at his (them) detention are taking part. Within the framework of this legal relationship, legal permission arises to cause harm to the detainee (of various types: property, physical, moral), to the extent necessary to prevent the offender from continuing socially dangerous acts and transferring the detainee to state authorities authorized to conduct a preliminary investigation.

We now turn to the characterization of the legal features of the institute we are studying, which have received coverage in the scientific literature. 
Different opinions are expressed in the literature as to which person may be detained, accompanied by possible harm.

It is believed that only sane persons who have reached the age of criminal responsibility can be detained, i.e. subjects of crime in the strict sense [2, p. 44]. This concept, despite the seemingly serious theoretical validity, seems unrealizable in a practical situation. For example, to establish the sanity of a person, a long study of his personality with the involvement of medical specialists is required. That is, a citizen who is detaining a criminal in any case cannot be completely sure of his sanity. It is also obvious that the exact age of the detainee is not always known. In addition, criminal liability for various crimes can arise from different ages, while the final qualification for a committed criminal act can only be given by a court, but not by a citizen detaining a criminal.

Another point of view boils down to the fact that any person who, as is clearly clear to the detainee, has committed a crime is subject to detention [12, p. 38.].

So, A.G. Kibalnik expresses the point of view that any person who has committed acts containing signs of a crime can be detained, including in cases where there are reasonable assumptions that the person will try to hide the traces of his illegal activities or continue to carry out his criminal intentions [3, p. 28].

Also interesting is the thought expressed by I.M. Tyazhkova regarding the fact that under the person who committed the crime in the sense of Art. 38 of the Criminal Code of the Russian Federation can also be understood as a subject convicted of its commission, but for some reason, avoiding the execution of punishment [14, p. 388].

The most critical position on the issue before us is presented by N.G. Kadnikov, who generally considers the wording of Art. 38 of the Criminal Code of the Russian Federation with regard to indications of a detained person not complying with applicable law [5, p. 114].

In our opinion, the legislator, using the wording "the person who committed the crime", understood rather as the person who was the offender who committed an act prohibited by criminal law, the socially dangerous nature of which is obvious to others.

Clarifications of the issue we are considering are clarified by the Resolution of the Plenum of the Supreme Court of the Russian Federation of September 27, 2012 No. 19 [8], which states that the detainee must be sure that it is the criminal who is doing the harm. The clarification notes that if the detainee in good faith was mistaken about the wrongfulness (criminal punishment) of the act, or about the age and sanity of the detained person, then his actions should still be evaluated according to the rule of Art. 38 of the Criminal Code. 
International Scientific and Practical Conference ECONOMICS, POLITICS, LAW: TRENDS AND PROSPECTS

Similarly, the Plenum of the Supreme Court recommends assessing situations of bona fide delusion of the detainee as to who committed the crime (paragraph 24).

It also does not matter if the criminal managed to complete his plan or not (paragraph 20), however, it is unacceptable to inflict any harm on other persons in the process of detention (paragraph 25).

Thus, the harm specified in Art. 38 of the Criminal Code is allowed in relation to any person whose actions have signs of a criminal offense and is not permissible in relation to other persons.

The norm considered by us establishes the right of any person (and not just law enforcement officers) to stop a crime and help bring the perpetrator to criminal responsibility [4, p. 56]. The clarifications of the aforementioned Plenum of the Supreme Court directly point to this socially significant aspect (paragraph 19).

Norm Art. 38 of the Criminal Code does not contain an answer to the question of what the harm entails, there is only an indication that it is not a crime. In our opinion, the wording "is not a crime" does not reflect the whole social essence of the criminal law institution that we characterize, actually equating it with innocent harm.

M.M. Pronin rightly notes in this connection that the content of Art. 38 of the Criminal Code of the Russian Federation, the wording does not reflect the true social essence of harm during detention, creates the wrong impression of its neutral significance for society and the state [11, p. nineteen].

Of course, from the point of view of criminal law, the division of acts into criminal and noncriminal is of interest, however, in the case we are considering, we are not just talking about an criminal act, but about an act that represents a certain benefit for society, despite the fact that it is accompanied externally causing harm, i.e. has external signs of public danger.

Thus, the category we are considering is dialectically characterized as a socially useful act in content and socially harmful in outward expression. This aspect has social significance; it leads to certain consequences for the criminal and the detainee, the whole society as a whole and the state.

In this regard, I.G. Plemadale even makes a proposal to include an incentive norm in the criminal law institute we are studying $[9$, p. 20].

However, we emphasize that the usefulness of the phenomenon under consideration characterizes its substantial side. Categories such as «public utility» and «social value» are more likely not criminal law, but socio-ethical. Objectively, society receives a useful result of the fight against crime, which, together with a positive example of socially active behavior of a detainee, has social value. At the same time, the external manifestation of the actions of the detainee is accompanied by harm to the detainee, which cannot be assessed as a socially useful result (for example, the 52 
International Scientific and Practical Conference

ECONOMICS, POLITICS, LAW: TRENDS AND PROSPECTS

offender receives injuries that lead to his disability). Therefore, the most objective is the assessment of harm during the detention of the offender, not as a socially useful action, but as acceptable for the interests of society.

The issue of a legal assessment of the actions of a detainee is relevant only if, as a result of such actions, damage to the interests protected by criminal law is inflicted. Thus, we are talking about such a specific sign of criminal law detention as the legality of causing damage to objects of criminal law protection.

The norms of the Special Part of the Criminal Code of the Russian Federation in this regard provide for liability for intentionally causing death (part 2 of article 108 of the Criminal Code of the Russian Federation) and grievous bodily harm or moderate damage to health (part 2 of article 114 of the Criminal Code of the Russian Federation) caused as a result of exceeding the permissible measures when detaining a criminal. In addition, in the criminal law there is a provision in clause " $\mathrm{g}$ " of part 1 of article 61 of the Criminal Code of the Russian Federation providing for such a circumstance mitigating punishment as a violation of the conditions of lawfulness of detention of the person who committed the crime.

Consequently, the legislator connects the social admissibility and legal legitimacy of harming a detained criminal with strict observance of the normatively established conditions and the limits of lawfulness, which, of course, must be singled out as an important sign of the criminal law institution that we are studying.

Important criminal law value is also the time of harm. Rightful, according to the meaning of Art. 38 of the Criminal Code is only the harm caused in the process of detention of the offender. Consequently, the infliction of any harm to a person who has ceased resistance (i.e., already actually detained) will not fall under the rule of Art. 38 of the Criminal Code.

The goals of causing harm are also important, namely: his detention, suppression of criminal acts, delivery of the detainee to the authorities. Any other purpose of harm (for example, revenge, lynching, etc.) will be unlawful.

It should be borne in mind that indicated in Art. 38 of the Criminal Code of the Russian Federation, the possibility of a criminal committing new socially dangerous acts does not at all imply any known pattern in the behavior of the detainee. We are talking in a broad sense of any degree of probability of a repeat of criminal attacks in the future.

Summarizing the above signs, we come to the conclusion that the harm caused during the detention of the person who committed the crime, as a circumstance excluding the crime of the act, should be considered as a socially permissible, legally lawful act, accompanied by harm to the objects of criminal law protection, if any and compliance with the criminal law conditions, grounds and limits. 
International Scientific and Practical Conference ECONOMICS, POLITICS, LAW: TRENDS AND PROSPECTS

\section{References}

1. Dmitrenko A.P. Circumstances Excluding the Crime of Deed in the Criminal Law of the Russian Federation: Monograph / A.P. Dmitrenko. - M .: Ileksa, 2010 .-- 344 p.

2. Ivanov A.B. Institute for causing harm during the detention of the person who committed the crime: a training manual / A.B. Ivanov. - M.: Prospect, 2014 --- 188 p.

3. Kibalnik A.G. Circumstances Excluding the Crime of an Act: Monograph / A.G. Kibalnik. - M $\therefore$ Yurlitinform, 2013 .- $402 \mathrm{p}$.

4. Klyuev A.A. The legality of causing harm during the detention of the person who committed the crime / A.A. Klyuev // Russian Justice. - 2015. - No. 5. - S. 56-59.

5. Commentary on the Criminal Code of the Russian Federation / Ed. ed. H.G. Kadnikova. - M .: Norma, 2014 .-- 825 p.

6. Kondrashova O.V. Criminal legal assessment of harm during the detention of a person who has committed a socially dangerous assault. / O.V. Kondrashova. - Tyumen: TUI, 2004 .- 125 p.

7. Nikulenko A.V. Actual problems of legal regulation of harm during the detention of a person who committed a socially dangerous act / A.V. Nikulenko // The Criminal Code of the Russian Federation 15 years: achievements, problems, trends: a collection of scientific articles. - $\mathrm{SPb}$.: SPbGUEF, 2012 .-- S. 118-127.

8. On the application by the courts of legislation on necessary defense and harm during the detention of the person who committed the crime: Resolution of the Plenum of the Supreme Court of the Russian Federation of September 27, 2012 No. 19 // Rossiyskaya Gazeta. - No. 227. - 2012.

9. Plamedyale I.G. Causing harm during the detention of the person who committed the crime / I.G. Plamediale. - M.: Prospect, 2017 .-- 126 p.

10. Ponomar V.V. Causing harm during the detention of a person who committed a crime, as a circumstance excluding the crime of an act: monograph / V.V. Sexton. - M .: ANO «Legal programs», 2016. - 334 p.

11. Pronina M.M. Causing harm during the detention of the person who committed the crime: criminal law regulation and its improvement / M.M. Pronina. - Chelyabinsk: URGUA, 2015 --- 127 p.

12. Rabadanov A.S. Necessary defense and harm during the detention of the person who committed the crime: a training manual / A.S. Rabadanov. - Saratov: SUI, 2013 .-- 161 p.

13. Sichinava I.R. Causing harm during the detention of the person who committed the crime (criminal law aspects) / I.R. Sichinawa. - Rostov-on-Don: Phoenix, 2014 .-- 124 p.

14. The criminal law of Russia. General part: Textbook for universities / Ed. N.F. Kuznetsova and I.M. Heavy. - M .: Norma, 2012 .-- 538 p.

15. Yakunina S.A. Causing harm during the detention of the person who committed the crime / S.A. Yakunin. - Rostov-on-Don: Phoenix, 2015 .-- 126 p. 
International Scientific and Practical Conference

ECONOMICS, POLITICS, LAW: TRENDS AND PROSPECTS

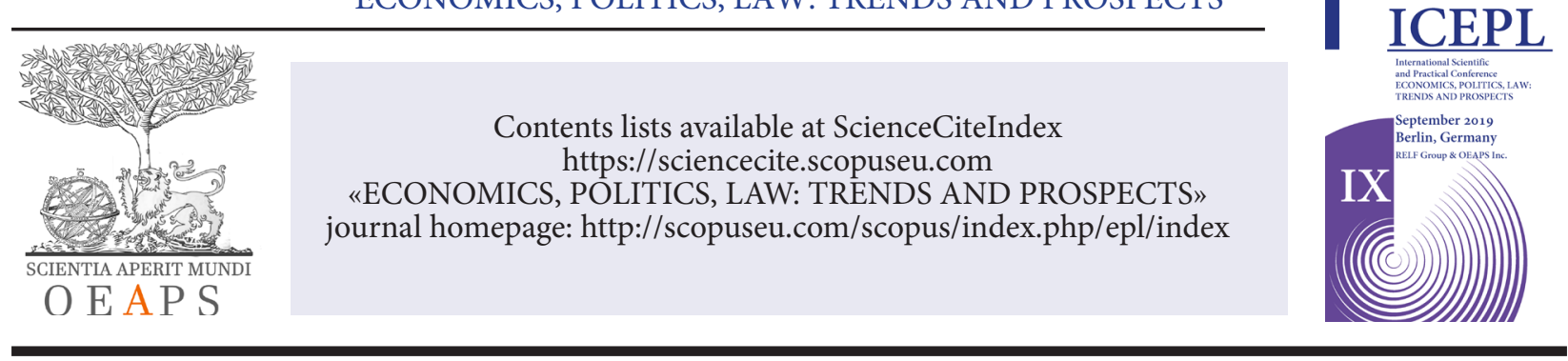

УДК 336

Ипотечное кредитование в России: приоритетные направления развития

Желябовская Магдалина Владимировна

студентка направления «Экономика»

ФГОБУ ВО «Финансовый университет при Правительстве Российской Федерацииџ»

2. Краснодар, Россия

planeta.zhelyabovskaya@bk.ru

Mortgage lending in Russia: priority dicrections of development

Zhelyabovskaya Magdalina Vladimirovna

student of the direction "Economics»,

Federal State Budgetary Educational of Higher Education

«Financial University under the Government of the Russian Federation» Krasnodar, Russia

Аннотация: В статье рассматривается вопрос развития рынка банковского ипотечного кредитования и тенденций его развития на современном этапе функционирования экономики России. В настоящее время ипотека играет ключевую роль в социально-экономическом развитии населения, обеспечивая граждан доступным жильем. Рассмотрены программы государственной поддержки для ипотечного кредитования в Российской Федерации.

Ключевые слова: ипотечное кредитование, программы государственной поддержки, экономика, просроченная задолженность.

Abstract: The article deals with the development of the Bank mortgage lending market and the trends of its development at the present stage of the Russian economy. Currently, mortgage plays a key role in the socio-economic development of the population, providing citizens with affordable housing. Programs of the state support of mortgage crediting in the Russian Federation are considered. Directions of improvement of the mechanism of state regulation of mortgage lending in Russia are offered.

Keyword: mortgage lending, government support programs, economy, overdue debt.

(C) 2019 The Author. Published by OEAPS Inc. This is an open access article under the CC BY-NC-ND license (http://creativecommons.org/licenses/by-nc-nd/4.0/) 
International Scientific and Practical Conference ECONOMICS, POLITICS, LAW: TRENDS AND PROSPECTS

Основным стратегическим направлением отечественной экономики является разработка социальной программы по выходу государства на общемировые параметры уровня и качества жизни населения. Важность ипотечного жилищного кредитования обусловливается тем, что его развитие стимулирует адекватное функционирование жилищного строительства, а также смежных со строительством отраслей реального сектора экономики.

Рынок ипотечного жилищного кредитования регулируется следующими нормативными актами Российской Федерации: Ф3 № 102 «Об ипотеке (залога недвижимости» [11], Ф3 № 395-1 «О банках и банковской деятельности» [9], Ф3 № 4015-1 «Об организации страхового дела в Российской Федерации» [13], ЖК РФ [6], ФЗ №218 «О государственной регистрации недвижимости» [10], Ф3 №218 «О кредитной истории» [12].

На становление и развитие рынка ипотечного кредитования оказывают влияние целый комплекс внешних и внутренних факторов (рисунок 1).

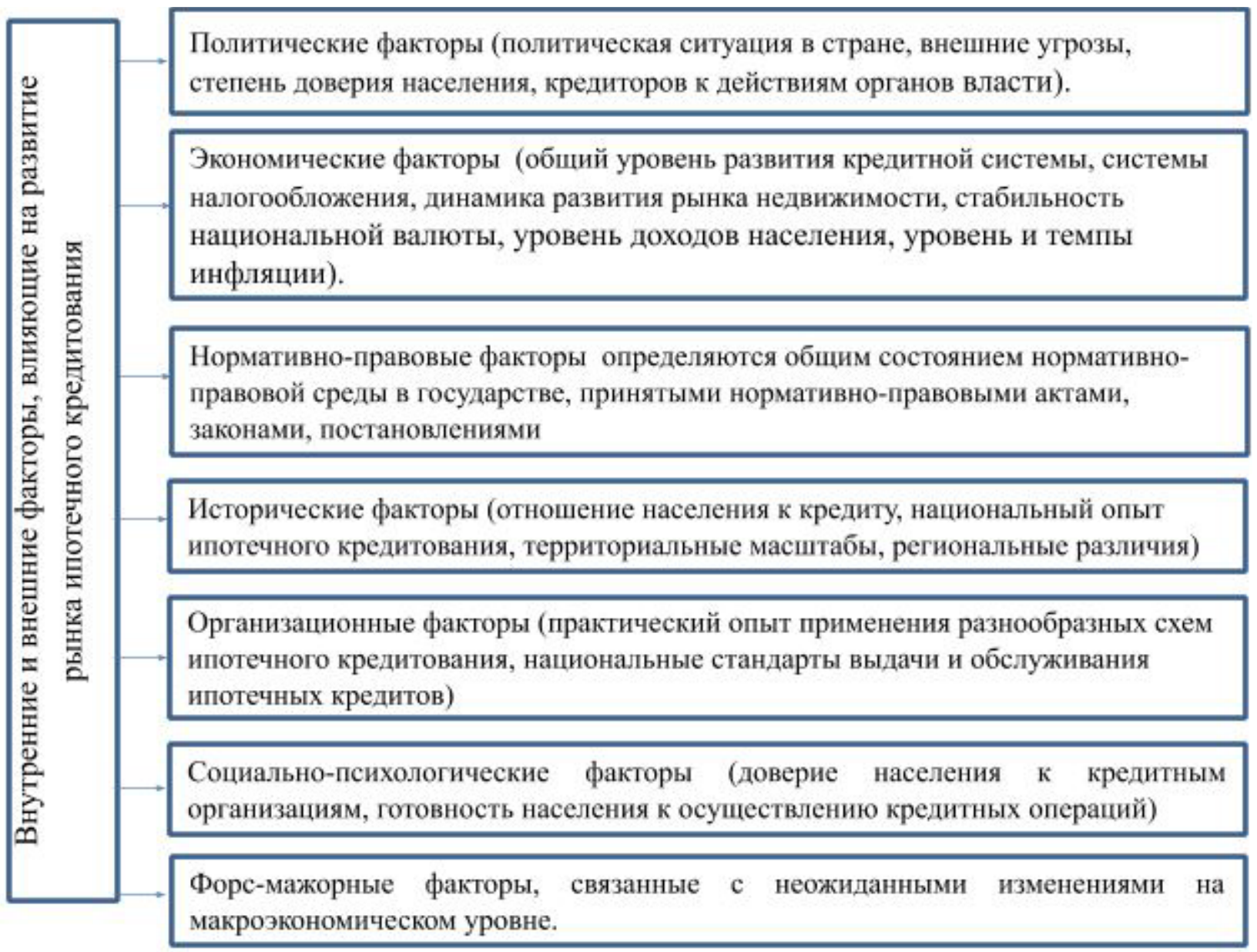

Рисунок 1. Внутренние и внешние факторы оказывающие влияние на развитие рынка ипотечного кредитования [2] 
Вышеизложенные внешние и внутренние факторы оказывают как неблагоприятное влияние на развитие ипотечного жилищного кредитования, так и стимулирующее. Государство должно стремиться минимизировать неблагоприятные факторы и стимулировать позитивные факторы для дальнейшего развития ипотечного кредитования. Поскольку именно ипотечное кредитование является эффективным инструментом решения проблемы обеспеченности жильем граждан Российской Федерации, значимым механизмом регулирования денежной массы, одним из основных направлений в достижении экономического роста в целом.

Изучим анализ рынка ипотечного жилищного кредитования в России за 2008-2018 года (рисунок 2). За анализируемый период, наблюдается значительное сокращение кредитных организаций на территории России на 575 штук (с 1136 по 561). Основными причинами «зачистки» банковский организаций является отзыв лицензии на осуществлении банковской деятельности, в связи с неисполнением нормативных актов Банка России, а также применение Центральным Банком жесткой политики по урегулированию деятельности кредитных организаций [1].

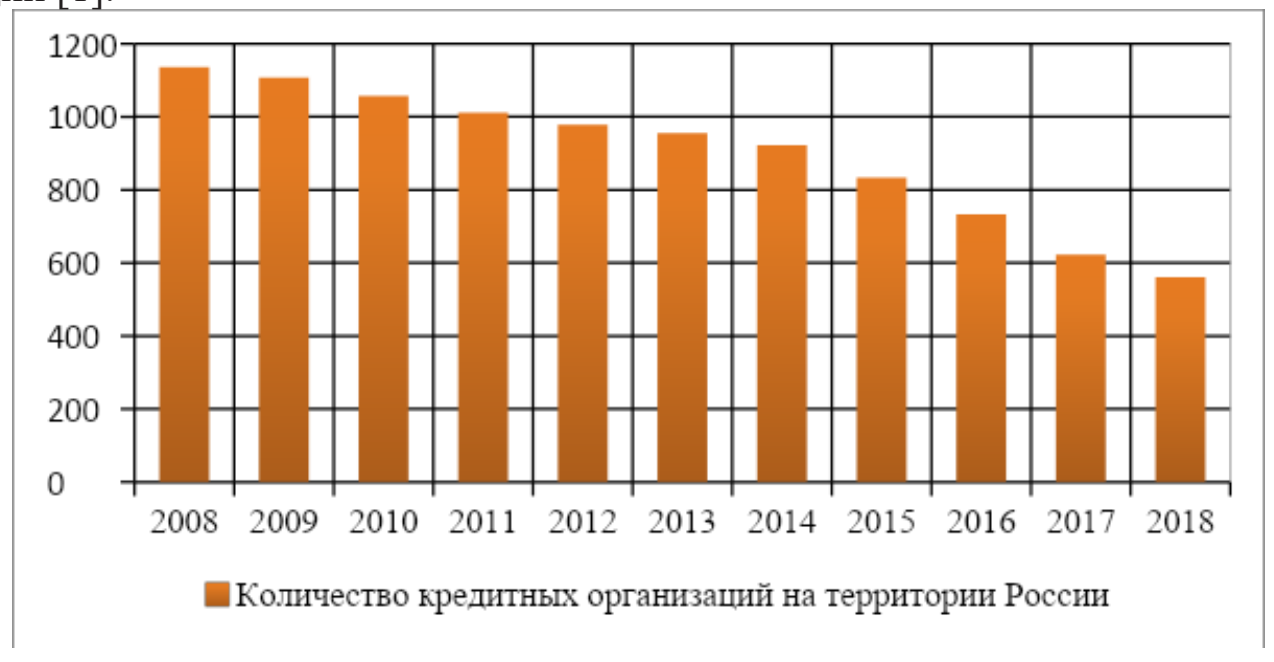

Рисунок 2. Количество банковских организации в России за 2008-2018 гг. [14]

Динамика объема предоставленных ипотечно жилищных кредитов в России за 11 лет представлена на рисунке 3. Основными причинами уменьшения объемов ипотечного жилищного кредитования как в 2008 году, так и в 2009 году явились удорожание кредитных ресурсов, а также возрастающие риски вложений в долгосрочные активы при снижении возможности рефинансирования кредитными организациями ранее выданных ипотечных жилищных кредитов.

По итогам 2011 года объем ипотечного кредитования, превысил исторический «максимум» 2008 года. Объем предоставленных ипотечных жилищных кредитов составил 717 млрд. руб. (против 656 млрд. руб. в 2008 году), что на 90\% больше результатов 2010 года. Рекордный 
рост был во многом обеспечен ускорением рынка, на фоне усиления нестабильности на финансовых рынках и анонсирования отдельными банками планов по повышению ипотечных ставок. С 2012 - 2015 гг. наблюдается динамика к увеличению объема предоставленных ипотечных жилищных кредитов.

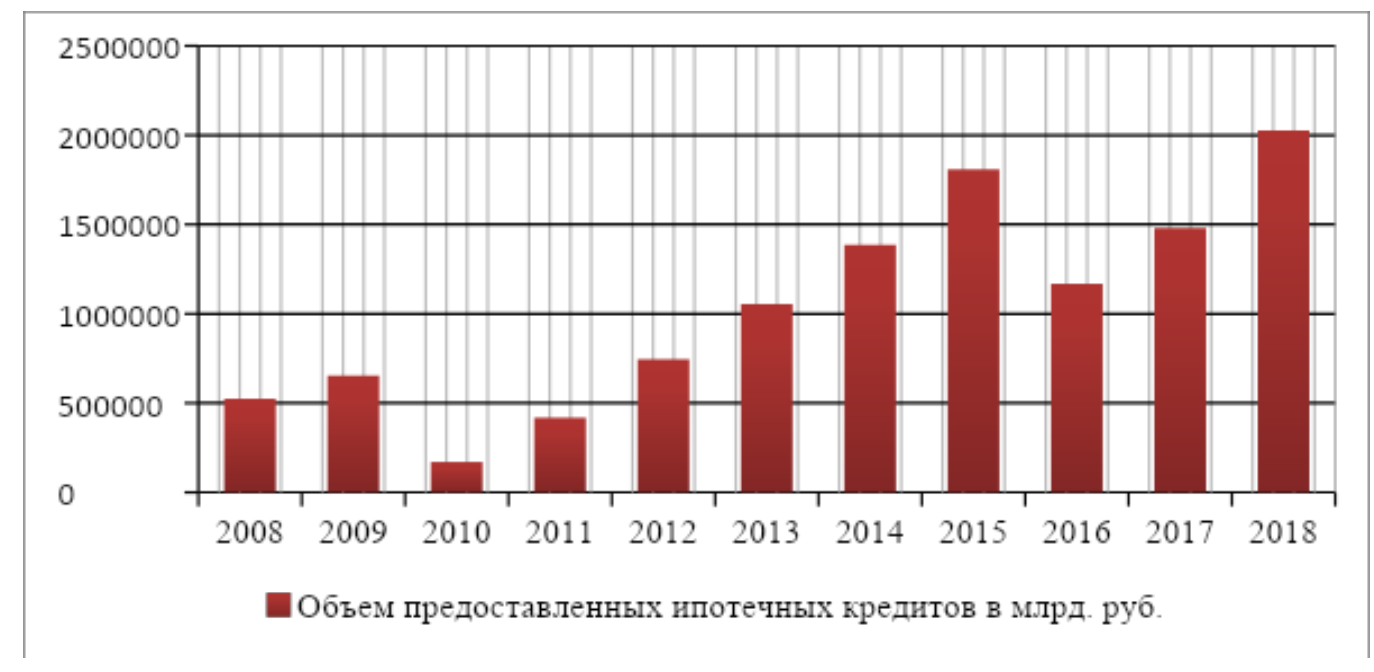

Рисунок 3. Объем предоставленных ипотечных жилищных кредитов в России за 2008-2018 гг. в (млрд. руб) [14]

В 2016 году кредитными организациями было предоставлено 856461 ипотечных жилищных кредитов на сумму 1169240 млрд. рублей , доля в объеме кредитов физическим лицам составила 20,4\%, увеличившись по сравнению с предыдущим годом на 0,6 п.п., вернувшись тем самым на уровень 2014 года. Рост рынка ипотечного кредитования обеспечивался в большей степени рублевыми кредитами. Ипотечное кредитование в иностранной валюте по-прежнему теряют свою привлекательность среди населения. Доля валютных ипотечных кредитов, предоставленных в 2017 году, была минимальной за всю историю наблюдений $0,03 \%$. На рисунке 4 представлена динамика средневзвешенной процентной ставки в рублях и валюте за 10 лет. 


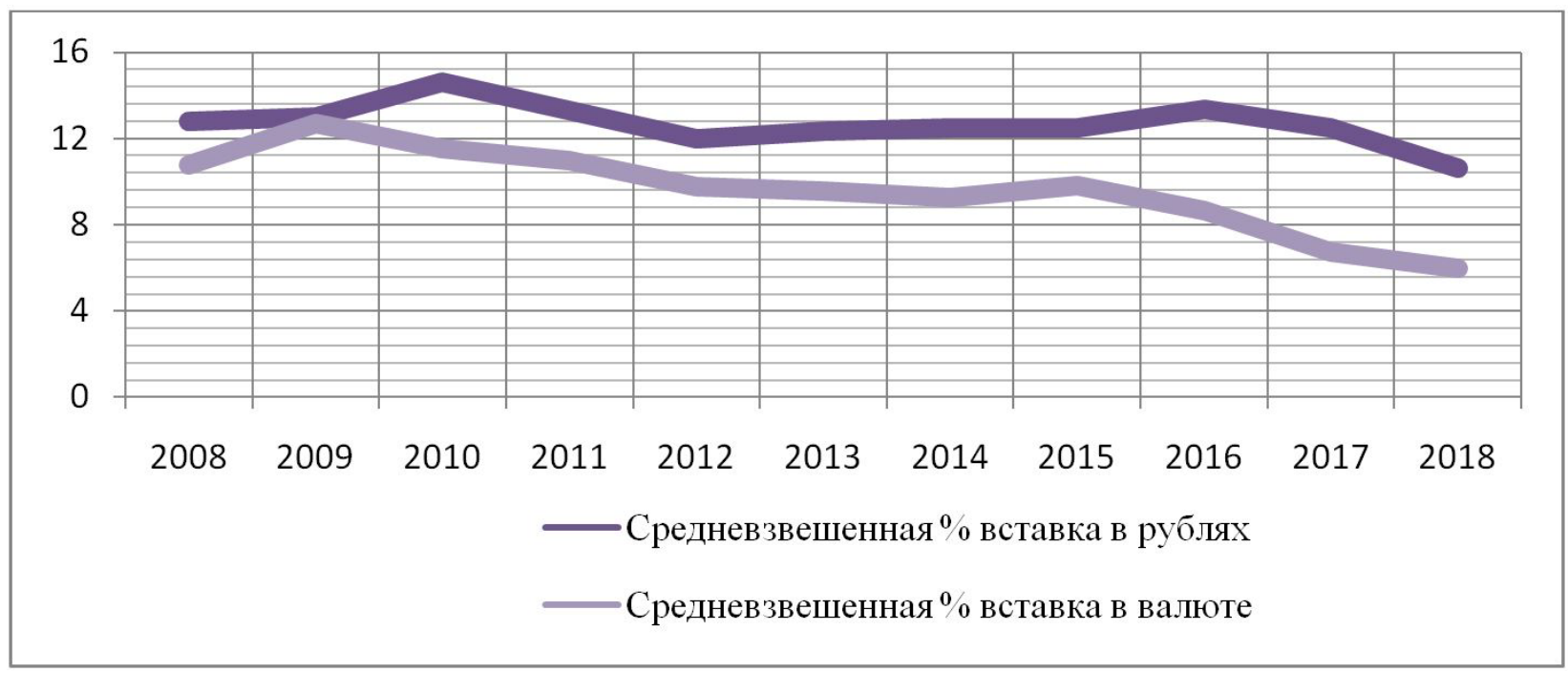

Рисунок 4. Динамика средневзвешенной вставки по предоставленным ипотечным жилищным кредитам за 2008-2018 гг. в рублях, \% [14]

Анализируя динамику изменения процентной ставки по выданным ипотечным кредитам за период с 2008 по 2018 г. надо отметить, что самый высокий уровень сложился по итогам 2010 года 14,59\%. За рассматриваемый период процентная вставка по ипотеке в рублях уменьшилась на 3,24\% (с 12,8\% до 9,56\%), а в валюте на 4,8 п.п. (с 10,8\% до 6\%).

По мнению, многих экспертов в ближайшем будущем ставка по ипотечным кредитам в рублях будет в районе 8-9\% для рядовых заемщиков, а для льготных заемщиков будет еще дешевле. Динамика просроченной задолженности по предоставленным ипотечным кредитам за 10 лет (рисунок 5).

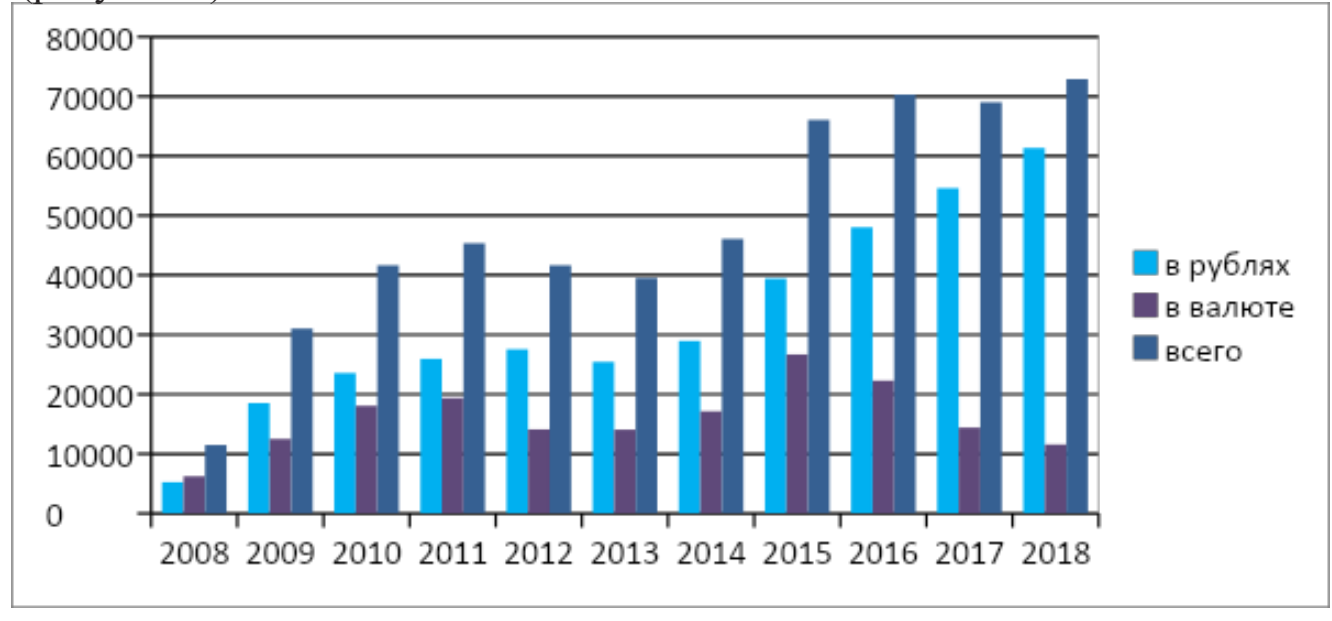

Рисунок 5. Динамика просроченной задолженности по предоставленным ипотечным жилищным кредитам за 2008-2018 года в (млн. руб.) [14] 
International Scientific and Practical Conference ECONOMICS, POLITICS, LAW: TRENDS AND PROSPECTS

По данным Центрального Банка, за исследуемый период наблюдается увеличение просроченной задолженности с 11483млн. руб. до 72865 млн. руб. С 2009 года наблюдается устойчивая тенденция к увеличению объемов просроченной задолженности по сравнению с 2008 годом в 3,5 раза, в иностранной валюте в 2 раза и составила по состоянию на начало 2010 года 18,5 и 12,5 млрд. руб. соответственно.

С начала 2015 года по сравнению с 2014 годом величина задолженности по ипотечным жилищным кредитам в рублях увеличилась на $33,7 \%$, а в иностранной валюте на $21,9 \%$. Удельный вес просроченной задолженности по ипотечным жилищным кредитам в рублях и иностранной валюте в общей сумме задолженности по ипотечным жилищным кредитам незначительно снизился: на 1 января 2015 года по сравнению с 1 января 2014 года на 0,1 п.П., составив 0,9 и $12,6 \%$ соответственно.

Совокупная задолженность по ипотечным жилищным кредитам на конец 2017 года достигла 5,2 трлн. рублей, увеличившись за год на $15,4 \%$. При этом продолжилось существенное сокращение задолженности по ипотечным кредитам в иностранной валюте. На 1 января 2018 года величина задолженности по ИЖК в рублях по сравнению с 1 января 2017 года увеличилась на $16,3 \%$, составив 5144,9 млрд. рублей. При этом удельный вес просроченной задолженности по ИЖК в рублях практически не изменился и составил менее $1,1 \%$. Динамика ипотечного жилищного кредитования в разрезе федеральных округов по состоянию на 2018 год представлена на рисунке 6.

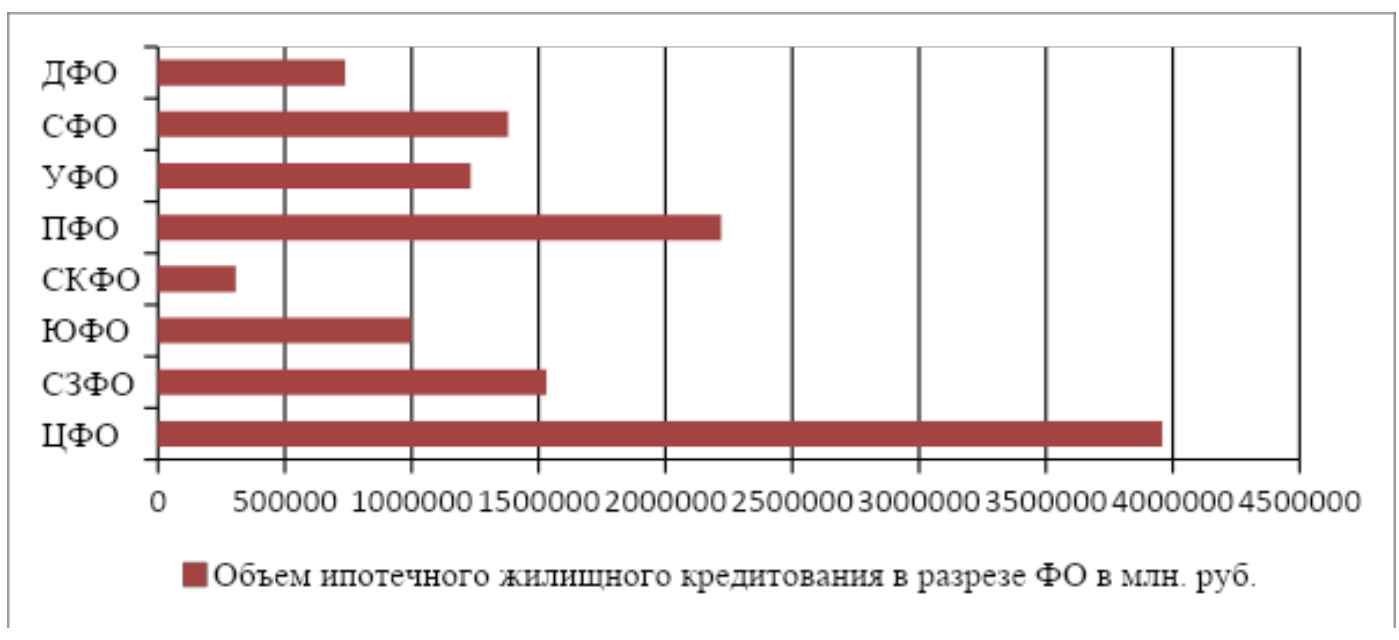

Рисунок 6. Динамика ипотечного жилищного кредитования в разрезе федеральных округов по состоянию на 2018 год в (млн. руб.) [14]

Из представленных выше данных видно, что большая часть ИЖК была выдана в Центральном ФО, из них большинство - в Москве и Московской области. На жителей ЦФО пришлось 
International Scientific and Practical Conference

ECONOMICS, POLITICS, LAW: TRENDS AND PROSPECTS

$32,32 \%$ из оформленных по всей стране ипотечных кредитов, их общая сумма составила 110 185 млн. рублей. Меньше всего ИЖК оформлено в Северо-Кавказском ФО - 2,07\% от общего объема по стране, на сумму 7043 млн. рублей. На рисунке 7 представлен рейтинг банков в России по ипотечным жилищным кредитам за 2018 год.

Как видно, из рисунка 7, структура участников ипотечного рынка в 2018 году не изменилась. Лидерами на рынке ипотечного кредитования на протяжении многих лет остаются «Сбербанк», «ВТБ 24» и «Газпромбанк». Основным фактором, влияющим на их устойчивые позиции, можно назвать государственное участие. Наибольший прирост портфеля по итогам 2018 года показали Абсолют Банк, ФК Открытие и Альфа Банк.

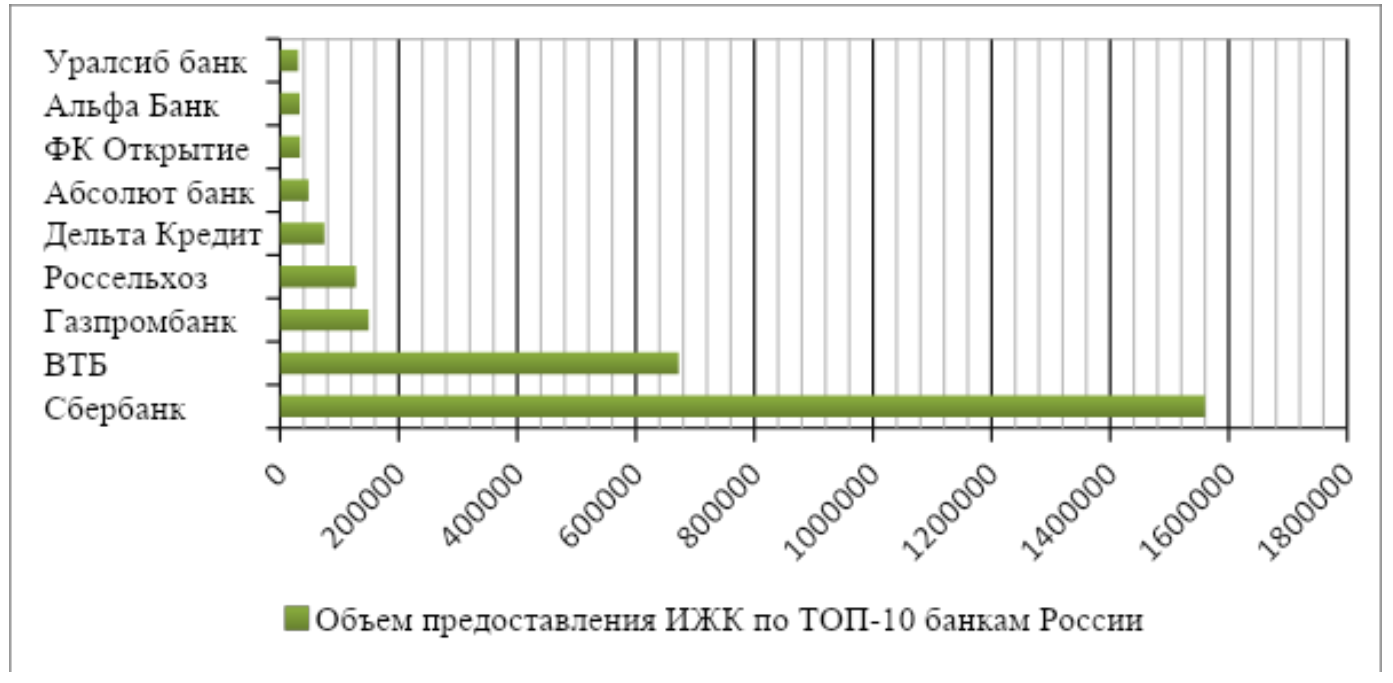

Рисунок 7. Рейтинг банков в России по предоставлению ипотечных жилищных кредитов за 2018 год [14]

В соответствии с положениями Концепции развития системы ипотечного жилищного кредитования в Российской Федерации, которая была утверждена Правительством России, современная государственная жилищная политика ориентирована на оказание поддержки в решении жилищных проблем основной части работающего населения, имеющего средние доходы, накопления и имеющие в собственности жилье, полученное посредством приватизации. Рассмотрим некоторые госпрограммы по ипотеке в России (таблица 1). 
Таблица 1 - Перечень и характеристика государственных программ по ипотеке в России

\begin{tabular}{|c|c|}
\hline $\begin{array}{c}\text { Название } \\
\text { программы }\end{array}$ & Характеристика \\
\hline 1 & 2 \\
\hline $\begin{array}{l}\text { Программа } \\
\text { «Молодая } \\
\text { семья» }\end{array}$ & $\begin{array}{l}\text { Льготная ипотека для молодой семьи в } 2018 \text { году предназначена для семей, в которых } \\
\text { каждому супругу не исполнилось } 35 \text { лет, при этом они официально зарегистрировали свои } \\
\text { отношения. Вторым обязательным требованием для участия в программе выступает пребы- } \\
\text { вание семьи в очереди на улучшение жилищных условий. }\end{array}$ \\
\hline $\begin{array}{l}\text { Ипотека для } \\
\text { военных }\end{array}$ & $\begin{array}{l}\text { Участникам военной ипотеки ежегодно начисляется на лицевой счет сумма, которая в } 2018 \\
\text { году составляет почти 268, } 5 \text { тыс. рублей. Три года участия в программе предоставляют во- } \\
\text { еннослужащему право оформить льготный ипотечный кредит с господдержкой, в котором } \\
\text { накопленные за это время денежные средства могут использоваться в качестве первона- } \\
\text { чального взноса или платежа по займу. Максимальная сумма кредита при этом составляет } \\
\text { в } 2018 \text { году около 2,33 млн. рублей. }\end{array}$ \\
\hline $\begin{array}{l}\text { Ипотека для } \\
\text { молодых } \\
\text { ученых и } \\
\text { педагогов }\end{array}$ & $\begin{array}{l}\text { Предоставляются право получить льготную ипотеку молодым ученым и педагогам. Кон- } \\
\text { кретные ее условия в значительной степени определяются региональными властями, тем } \\
\text { не менее, некоторые общие моменты можно выделить: } \\
\text { - Участвовать в программе могут специалисты, которым еще не исполнилось } 35 \text { лет. Ис- } \\
\text { ключение из этого правила сделано для докторов наук, которые могут оформить льготный } \\
\text { ипотечный кредит вплоть до наступления } 40 \text { лет; } \\
\text { - Участник обязан иметь собственные средства в размере, как минимум, 10\% от стоимости } \\
\text { жилья; } \\
\text { - Помощь государства заключается в субсидировании \% ставки и разовом предоставлении } \\
\text { до 20\% от суммы, необходимой на приобретение жилой недвижимости. }\end{array}$ \\
\hline $\begin{array}{l}\text { Социальная } \\
\text { ипотека }\end{array}$ & $\begin{array}{l}\text { Предназначена, прежде всего, для поддержки малоимущих категорий граждан, а также } \\
\text { россиян, остро нуждающихся в улучшении жилищных условий. Основными условиями } \\
\text { ипотечного кредитования в данном случае являются: } \\
\text { - Продажа жилой недвижимости, принадлежащей государству, по цене, которая в 1,5-2 раза } \\
\text { ниже рыночной; } \\
\text { - Предоставление субсидий на погашение процентной ставки; } \\
\text { - Предоставление жилищного сертификата на сумму первоначального взноса. } \\
\text { Для участия в социальной ипотеке потенциальному заемщику необходимо иметь, как ми- } \\
\text { нимум, 10\% от стоимости приобретаемого жилья. Вторым требованием выступает нали- } \\
\text { чие официального трудоустройства. }\end{array}$ \\
\hline $\begin{array}{l}\text { Мате- } \\
\text { ринский } \\
\text { капитал }\end{array}$ & $\begin{array}{l}\text { Программа предоставления при рождении второго и третьего ребенка материнского ка- } \\
\text { питала продлена до } 2022 \text { года. Полученный при этом сертификат активно используется, } \\
\text { когда оформляется ипотека для многодетной семьи. Средства семейного капитала, размер } \\
\text { которого в } 2018 \text { году составляет } 453 \text { тыс. рублей, могут быть использованы и в качестве } \\
\text { стартовой выплаты на покупку жилья, и для погашения долга по ипотечному кредиту. }\end{array}$ \\
\hline
\end{tabular}




\begin{tabular}{|c|c|}
\hline $\begin{array}{l}\text { Реструк- } \\
\text { туризация } \\
\text { ипотеки }\end{array}$ & $\begin{array}{l}\text { Государственная программа, предусматривающая льготные условия реструктуризации } \\
\text { ипотечных кредитов для определенных категорий заемщиков, была введена в } 2015 \text { году. } \\
\text { Воспользоваться государственной поддержкой при реструктуризации ипотеки могут следу- } \\
\text { ющие категории заемщиков: } \\
\text { - Участники боевых действий; } \\
\text { - Многодетные семьи; } \\
\text { - Родители и попечители лиц с ограниченными возможностями; } \\
\text { - Работники бюджетных учреждений и органов государственной власти. } \\
\text { Условием для получения финансовой помощи из бюджета выступает получение заемщиком } \\
\text { дохода, не превышающего два прожиточных минимума. В этом случае он может претендо- } \\
\text { вать на снижение процентной ставки, разовую субсидию или предоставление кредитных } \\
\text { каникул. }\end{array}$ \\
\hline
\end{tabular}

Развитие программ ипотечного жилищного кредитования помогает россиянам выбирать наиболее удобные условия для кредитования, однако, не все граждане могут обратиться к ипотечному жилищному кредитованию. Данная проблема требует решения со стороны государства не только на федеральном, но и на региональном уровне, так как в большинстве субъектов РФ рынок ипотечного жилищного кредитования недостаточно развит.

На мой взгляд, можно выделить несколько направлений, способных стимулировать дальнейшее развитие ипотечного кредитования в Российской Федерации:

- совершенствование законодательной базы в области ипотечного кредитования.

- изменение участников рынка ипотечного кредитования и приоритетов кредитной политики. В условиях жесткого регулирования рынка ЦБ РФ, банки изменяют свою кредитную политику, ужесточая требования к заемщикам в целях снижения кредитного риска и уменьшения объемов резервов под обесценение ссуд. Однако не все банки способны поддерживать конкурентоспособность в изменяющихся условиях, следовательно, на рынке ипотечного кредитования останутся наиболее развитые российские банки, способные быстро реагировать на внешние факторы.

- конкуренция на рынке ипотечного кредитования стимулирует создание новых банковских ипотечных продуктов.

Таким образом, объемы ипотечного жилищного кредитования увеличиваются, это значит, что экономическое положение страны постепенно стабилизируется. А развитие ипотечных программ в России позволяет все большему количеству людей приобрести недвижимость и улучшить свои жилищные условия.

\section{Список литературы}

1. Адаменко А.А., Желябовская К.В. Основные тенденции развития банковского сектора в Российской Федерации//Вестник академий знаний №31(2). 2019 - С. 263 - 266.

2. Соболева Е.С., Хан В.В. Основные направления развития ипотечного кредитования в России // Вопросы современной науки: новые перспективы Сборник статей Международной научно-практической конференции. 2017 - С. 35-38. 
International Scientific and Practical Conference

ECONOMICS, POLITICS, LAW: TRENDS AND PROSPECTS

3. Тарабукина О.А. Государственная поддержка ипотечного жилищного кредитования // Вестник науки и образования. №14 (50). 2018. - С. 29 - 32.

4. Федотова Г.В., Пивкина Е.В. Особенности ипотечного кредитования в России // поколение будущего: взгляд молодых ученых- 2017. Сборник научных статей 6-й Международной молодежной научной конференции. - С. 359-365.

5. Гражданский кодекс Российской Федерации (часть вторая) от 26.01.1996 №14-Ф3 (ред. от 28.12.2013) - http://www.consultant.ru/

6. Жилищный кодекс Российской Федерации от 29.12.2004 № 188-ФЗ (ред. от 26.07.2019) http://www.consultant.ru/

7. О мерах по развитию системы ипотечного жилищного кредитования в Российской Федерации: Постановление Правительства РФ от 11.01.2000 № 28 (ред. от 08.05.2002) - http:// www.consultant.ru/

8. О реализации отдельных мероприятий государственной программы Российской Федерации «Обеспечение доступным и комфортным жильем и коммунальными услугами граждан Российской Федерации»: Постановление Правительства РФ от 17.12.2010 № 1050 (ред. от 27.08.2018) - http://www.consultant.ru/

9. Федеральный закон «О банках и банковской деятельности» от 02.12.1990 № 395-1 - http:// www.consultant.ru/

10. Федеральный закон «О государственной регистрации недвижимости» от 13.05 .2015 № 218-Ф3 - http://www.consultant.ru/

11. Федеральный закон «Об ипотеке (залоге недвижимости)» от 16.07.1998 № 102-Ф3-http:// www.consultant.ru/

12. Федеральный закон «О кредитных историях» от 30.12.2004 № 218-Ф3 - http://www. consultant.ru/

13. Закон РФ от 27 ноября 1992 г. N 4015-I «Об организации страхового дела в Российской Федерации» - http://www.consultant.ru/

14. Официальный сайт Центрального Банка России - http://www.cbr.ru/

\section{The text of the article in English}

The main strategic direction of the domestic economy is the development of a social program for the state to reach global parameters of the level and quality of life of the population. The importance of mortgage housing lending is due to the fact that its development stimulates the adequate functioning of housing construction, as well as related industries with the construction of real sectors of the economy.

The mortgage lending market is regulated by the following regulatory acts of the Russian Federation: Federal Law No. 102 "On Mortgages (Real Estate Pledges" [11], Federal Law No. 395-1 "On Banks and Banking Activities" [9], Federal Law No. 4015-1 "On the Organization of Insurance affairs in the Russian Federation "[13], RF LC [6], Federal Law No. 218" On State Registration of Real Estate "[10], Federal Law No. 218“ On the Credit History "[12]. 
International Scientific and Practical Conference

ECONOMICS, POLITICS, LAW: TRENDS AND PROSPECTS

The whole formation and development of the mortgage lending market is influenced by complex internal and external factors (Figure 1).

Figure 1 internal and external factors ca. binding effect on the development of the mortgage market [2] (RU Vers)

The above-mentioned external and internal factors have as an adverse effect on the development of mortgage lending, as well as stimulating. The government should seek to minimize the adverse factors and promote the positive factors for the further development of mortgage lending. Since it is the mortgage lending is an effective tool to solve the problem of housing for citizens of the Russian Federation, a significant mechanism for Money supply regulation is one of the main directions in achieving economic growth in general.

We will study the analysis of the mortgage lending market in Russia for 2008-2018 (Figure 2). For the analyzed period, there is a significant reduction in credit institutions in Russia by 575 pieces (from 1136 to 561). The main reasons for the "sweeping" of banking organizations is the revocation of a banking license due to failure to comply with Bank of Russia regulations, as well as the Central Bank's tight policy to regulate the activities of credit organizations [1].

Figure 2 - The number of banking organizations in Russia for 2008-2018. [14] (RU Vers)

The dynamics of the volume of mortgage loans granted in Russia for 11 years is shown in Figure 3. The main reasons for the decrease in mortgage lending in 2008 and 2009 were the increase in credit resources, as well as increasing risks of investing in long-term assets when reducing the possibility of refinancing by credit organizations of previously issued mortgage housing loans.

According to the results of 2011, the volume of mortgage lending exceeded the historical «maximum» of 2008. The volume of mortgage loans granted amounted to 717 billion rubles. (against 656 billion rubles in 2008), which is $90 \%$ more than the 2010 results. Record growth was largely driven by market acceleration, amid growing instability in the financial markets and the announcement by individual banks of plans to increase mortgage rates. From 2012 - 2015 there is a trend towards an increase in the volume of mortgage loans provided.

Figure 3 - The volume of mortgage loans granted in Russia in 2008-2018. in (billion rubles) [14] (RU Vers)

In 2016, credit institutions provided 856461 mortgage housing loans in the amount of 1169240 billion rubles, the share in the volume of loans to individuals amounted to $20.4 \%$, an increase of 0.6 percentage points over the previous year., thereby returning to the level of 2014. The growth of the mortgage market was provided to a greater extent by ruble loans. Mortgages in foreign currencies still lose their attractiveness among the population. The share of foreign currency 
International Scientific and Practical Conference

ECONOMICS, POLITICS, LAW: TRENDS AND PROSPECTS

mortgage loans provided in 2017 was minimal in the entire history of observations - $0.03 \%$. Figure 4 shows the dynamics of the average interest rate in rubles and currency over 10 years.

Figure 4 - Dynamics of the weighted average insert for granted mortgage housing loans for 20082018. in rubles, $\%$ [14] (RU Vers)

Analyzing the dynamics of changes in the interest rate on issued mortgage loans for the period from 2008 to 2018, it should be noted that the highest level was 14.59\% in 2010. Over the period under review, the interest insert on mortgages in rubles decreased by $3.24 \%$ (from $12.8 \%$ to $9.56 \%$ ), and in foreign currency by 4.8 percentage points. (from $10.8 \%$ to $6 \%$ ).

According to many experts, in the near future, the rate on mortgage loans in rubles will be in the region of $8-9 \%$ for ordinary borrowers, and for preferential borrowers it will be even cheaper. Dynamics of overdue debts on mortgage loans for 10 years (Figure 5).

Figure 5 - Dynamics of overdue debts on granted mortgage housing loans for 2008-2018 in (million rubles) [14] (RU Vers)

According to the Central Bank, over the period under review there is an increase in overdue debts from $11483 \mathrm{mln}$. rub. up to 72865 million rubles. Since 2009, there has been a steady tendency to increase the volume of overdue debt compared to 2008 by 3.5 times, in foreign currency by 2 times and amounted to 18.5 and 12.5 billion rubles at the beginning of 2010 . respectively.

Since the beginning of 2015, compared with 2014, the amount of debt on mortgage housing loans in rubles increased by $33.7 \%$, and in foreign currency by $21.9 \%$. The share of overdue debts on mortgage housing loans in rubles and foreign currencies in the total debt on mortgage loans was slightly reduced: as of January 1, 2015 compared with January 1, 2014 by 0.1 percentage points, amounting to 0.9 and $12.6 \%$, respectively.

The total debt on housing mortgage loans at the end of 2017 reached 5.2 trillion. rubles, an increase over the year by $15.4 \%$. At the same time, a significant reduction in mortgage debt in foreign currency continued. As of January 1, 2018, the amount of debt on HMLs in rubles compared to January 1, 2017 increased by $16.3 \%$, amounting to 5144.9 billion rubles. At the same time, the share of overdue debts on HMLs in rubles remained practically unchanged and amounted to less than $1.1 \%$. The dynamics of mortgage housing lending by federal districts as of 2018 is presented in Figure 6.

Figure 6 - Dynamics of mortgage housing lending by federal districts as of 2018 in (million rubles) [14] (RU Vers) 
From the above data it is clear that the majority of HMLs were issued in the Central Federal District, most of them in Moscow and the Moscow Region. Residents of the Central Federal District accounted for $32.32 \%$ of mortgages issued throughout the country; their total amount amounted to 110,185 million rubles. The MHL is least registered in the North Caucasus Federal District - 2.07\% of the total volume in the country, amounting to 7,043 million rubles. Figure 7 shows the rating of banks in Russia in mortgage housing loans for 2018.

As can be seen from Figure 7, the structure of the mortgage market participants in 2018 did not change. For many years, Sberbank, VTB 24 and Gazprombank have remained leaders in the mortgage lending market. The main factor influencing their stable positions is state participation. The highest portfolio growth at the end of 2018 was shown by Absolut Bank, Otkrytie FC and Alfa Bank.

Figure 7 - Rating of banks in Russia for the provision of housing mortgage loans for 2018 [14] (RU Vers)

In accordance with the provisions of the Concept for the Development of the Housing Mortgage Lending System in the Russian Federation, which was approved by the Government of Russia, the modern state housing policy is focused on providing support in solving housing problems the bulk of the working population, with average incomes, savings and owned housing, obtained through privatization. Consider some state mortgage programs in Russia (table 1).

Table 1 - The list and characteristics of state mortgage programs in Russia. (RU Vers)

The development of housing mortgage lending programs helps Russians choose the most convenient conditions for lending, however, not all citizens can apply for housing mortgage lending. This problem requires a solution on the part of the state not only at the federal, but also at the regional level, since in most constituent entities of the Russian Federation the mortgage lending market is underdeveloped.

In my opinion, there are several areas that can stimulate the further development of mortgage lending in the Russian Federation:

- improving the legislative framework in the field of mortgage lending.

- Change in the market for mortgage lending and credit policy priorities. In conditions of tight regulation of the market of the Central Bank of the Russian Federation, banks are changing their credit policy, tightening requirements for borrowers in order to reduce credit risk and reduce the amount of reserves for loan impairment. However, not all banks are able to maintain competitiveness in a changing environment, therefore, the most developed Russian banks that are able to quickly respond to external factors will remain in the mortgage market.

- competition in the mortgage market stimulates the creation of new banking mortgage products. 
International Scientific and Practical Conference

ECONOMICS, POLITICS, LAW: TRENDS AND PROSPECTS

Thus, the volume of mortgage housing lending is increasing, which means that the country's economic situation is gradually stabilizing. And the development of mortgage programs in Russia allows an increasing number of people to purchase real estate and improve their living conditions.

\section{References}

1. Adamenko A.A., Zhelyabovskaya K.V. The main trends in the development of the banking sector in the Russian Federation // Bulletin of the Academies of Knowledge No. 31 (2). 2019 - S. $263-266$.

2. Soboleva E.S., Khan V.V. The main directions of development of mortgage lending in Russia // Questions of modern science: new perspectives Collection of articles of the International scientific and practical conference. 2017 - S. 35-38.

3. Tarabukina O.A. State support of housing mortgage lending // Bulletin of science and education. No. 14 (50). 2018. - P. 29 - 32.

4. Fedotova G.V., Pivkina E.V. Features of mortgage lending in Russia // generation of the future: a view of young scientists - 2017. Collection of scientific articles of the 6th International Youth Scientific Conference. - S. 359-365.

5. The Civil Code of the Russian Federation (Part Two) dated 01/26/1996 No. 14-FZ (as amended on 12/28/2013) - http://www.consultant.ru/

6. The Housing Code of the Russian Federation dated December 29, 2004 No. 188- Federal Law (as amended on July 26, 2019) - http://www.consultant.ru/

7. On measures to develop a housing mortgage lending system in the Russian Federation: Decree of the Government of the Russian Federation of 11.01.2000 No. 28 (as amended of 08/08/2002 ) http://www.consultant.ru/

8. On the implementation of certain measures of the state program of the Russian Federation "Providing affordable and comfortable housing and utilities for citizens of the Russian Federation": Direction of the Government of the Russian Federation dated December 17, 2010 No. 1050 (as amended on August 27, 2018) - http://www.consultant.ru/

9. Federal Law «On Banks and Banking Activities» dated 02.12.1990 No. 395-1 - http: //www. consultant.ru/

10. The Federal Law “On State Registration of Real Estate" dated 05/13/2015 No. 218-Ф3 - http:// www.consultant.ru/

11. The Federal Law “On Mortgage (Real Estate Pledge)" of 07/16/1998 No. 102-FZ - http://www. consultant.ru/

12. The Federal Law "On Credit Histories" dated December 30, 2004 No. 218-FZ - http://www. consultant.ru/

13. The Law of the Russian Federation dated November 27, 1992 N 4015-I «On the organization of insurance business in the Russian Federation» - http://www.consultant.ru/

14. The official site of the Cent Bank of Russia - http://www.cbr.ru/ 
International Scientific and Practical Conference

ECONOMICS, POLITICS, LAW: TRENDS AND PROSPECTS

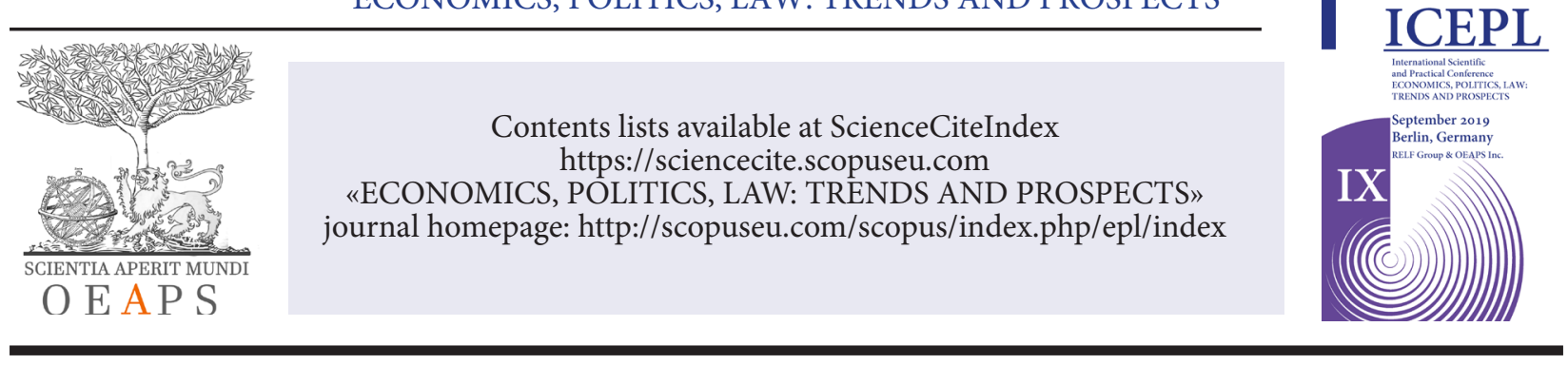

УДК 327.8

\title{
Инновационность как проявление государственного присутствия на международной арене
}

\author{
Хопей Мальвина \\ Аспирантка в Институте Международных Отношений, \\ Вроилавский Университет, город Вроилав, Республика Польша \\ malwina.hopej@gmail.com
}

\section{Innovativeness as a manifestation of state presence in the international arena}

\author{
Hopej Malwina \\ Ph. D. candidate, Institute of International Studies, \\ University of Wrockaw, Wrocław Poland
}

\begin{abstract}
Аннотация: В статье рассматривается важность инноваций и инновационности как определяющего фактора позиции государства в международных отношениях. Это глобальное присутствие представлено в Elcano Global Presence Index 2018, основанном на показателях, собранных в трех категориях: военная, экономическая и мягкая(soft). Дополнением является рейтинг Bloomberg Innovation Index 2018, который оценивает способность создавать инновации. Сопоставление этих двух подходов показывает, что высокие государственные расходы на инновации и большое количество патентных заявок не приводят к тому, что эта страна играет существенную роль на международной арене.

Ключевые слова: инновационность, инновации, глобальноеприсутствие, патент, технология.
\end{abstract}

Annotation:The article considers the importance of innovation and innovativeness as a determining factor of the state position in international relations. This global presence is represented in the Elcano Global Presence Index 2018, which is based on indicators collected in three categories: military, economic and soft power. An addition is the Bloomberg Innovation Index 2018, which assesses the ability to create innovations. A comparison of these two approaches shows that high public expenditures on innovations and a large number of patent applications do not lead to the fact that this country plays a significant role in the international arena.

Keywords: innovativeness, innovations, global presence, patent, technology.

(c) 2019 The Author. Published by OEAPS Inc. This is an open access article under the CC BY-NC-ND license (http://creativecommons.org/licenses/by-nc-nd/4.0/) 
Модель Elcano Global Presence Index [1] измеряет глобальное присутствие (анг. global presence), понимаемое как эффективное позиционирование в абсолютном выражении различных стран за пределами их границ в областях: экономической, военной и мягкой (aнг. softpower). Этим областям были присвоены весовые функции (процентные) в размере от $20 \%$ до $40 \%$ участия в создании эффекта присутствия на международной арене. Кроме того, эти категории подразделяются на 16 компонентных показателей, которые при правильном расчете формируют рейтинги экономического, мягкого и военного присутствия.

Если сложить их вместе, то они составят Elcano Global Presence Index 2018:

- военное присутствие (доля в формировании глобального государственного присутствия составляет 20\%) состоит только из двух элементов: численность военнослужащих (9\%), военная техника (11\%).

- экономическое присутствие $\mathbf{( 4 0 \% )}$. Квалифицированы пять показателей в этой области: энергетика (8\%), основные категории товаров (6\%), производство (8\%), услуги $(8 \%)$, инвестиции $(10 \%)$.

- мягкое присутствие (40\%) включает наибольшее число компонентов, а именно девять:миграция (4\%), туризм (4\%), спорт (3\%), культура (5\%), информация (5\%), технологии $(5 \%)$, наука (5\%), образование (5\%), сотрудничество в целях развития $(4 \%)$.

Технология, которая в данном отчете является синонимом инновационности, называется «количеством патентов, поданных в одной или нескольких странах» и основана на двух источниках и трех опциях для понимания:

Иностранно-ориентированные патенты: количество связанных патентных заявок на охрану одного и того же изобретения, поданных в одной или нескольких зарубежных странах. Источником является Статистическая база данных Всемирной организации интеллектуальной собственности (ВОИС, анг. World Intellectual Property Organization, WIPO).

Однако в случае стран Европейского союза технология определяется следующим образом: - Иностранно-ориентированные патенты всех государств-членов: количество взаимосвязанных патентных заявок, поданных в одну или несколько зарубежных стран для охраны одного и того же изобретения. Переменной величиной корректировки является число патентов, зарегистрированных для каждого государства-члена в других государствахчленах. Данные также поступают из баз данных ВОИС.

- Количество патентов, зарегистрированных в Европейском патентном ведомстве (ЕПВ, анг. European Patent Office, ЕРО) на основе данных Евростата.

Классически выделяются три сектора экономики [2]:

- сельскохозяйственный (первый) - охватывающий сельское хозяйство, лесное 
хозяйство, рыболовство и добычу полезных ископаемых;

- $\quad$ промышленный (второй) - охватывающий обрабатывающую промышленность и строительство;

- $\quad$ сектор услуг (третий) - охватывает услуги в широком смысле, такие как гостиничное дело, банковское дело, сектор высоких технологий и тд.

Иногда выделяется четвертый сектор - главным образом в силу его важности для информационного общества XXI века - касается получения, обработки и предоставления информации.

Поэтому стоит отметить, что по этому показателю технология не является частью экономического присутствия, а мягкой составляющей. Определение, принятое испанским Королевским институтом Элькано (анг. Royal Institute Elcano) относится к выдаче патентов, а значит и к результатам сотрудничества юристов и ученых из сектора НИОКР (Научно-исследовательские и опытно-конструкторские работы, анг. R\&D). Экономическое присутствие тесно связано со вторым сектором, формирующим внутренний валовой продукт (ВВП, анг. GDP), в то время как вопрос о патентах касается других компонентов мягкого присутствия, в основном сотрудничества в области информации, науки и развития.

Актуальность такой классификации подтверждается на примере отраслей, подавших заявки в ЕПВ. В 2017 году наибольшее число патентных заявок поступило из секторов медицинских технологий, цифровой связи и компьютерных технологий. С другой стороны, наибольший рост числа заявок был отмечен в секторах биотехнологий, фармацевтики и измерительного оборудования [3].

Патенты являются ключом к развитию любой национальной экономики - как развивающейся, так и развитой, основанной на современных технологиях. Местные технологии позволяют не только развивать конкурентоспособную промышленность, получать прибыль от лицензионных соглашений, инвестировать в иностранные рынки (прямые иностранные инвестиции, анг. foreign direct investment, FDI), но и создавать национальный брендинг (анг. nation branding) в сознании иностранных сообществ [4], и таким образом усиливать присутствие государства, являющееся «влиянием единицы за пределами ее границ».

В 2010 году ВОИС зарегистрировала 164 тысячи патентных заявок - изобретений, полезных моделей и т.д. Более $27 \%$ из них пришли из США (что означает более 44000 патентов), $19.6 \%$ из Японии и $10.7 \%$ из Германии [5]. Хотя Соединенные Штаты Америки по-прежнему являются самой инновационной страной в мире, их также воспринимают как гегемонию, абсолютную власть на международной арене, но при этом доминирующее положение сокращается с точки зрения количества заявок. В 2018 году США заняли первое место среди стран, обратившихся в ВОИС с запросами (55 981 запрос в 2018 г.), опередив Китай (53 340 
International Scientific and Practical Conference

ECONOMICS, POLITICS, LAW: TRENDS AND PROSPECTS

запросов) [6] лишь на 2641 запрос.

Интересно, что только с точки зрения инноваций, а не количества патентов, США занимают 8-е место, а Китай, который занимает первое место в списке по количеству поданных в ВОИС заявок, - 21-oe. Bloomberg Innovation Index 2018 [7]это рейтинг, оценивающий способность экономики стран создавать инновации. Именно поэтому Китай как развивающаяся страна, основанная на воспроизводстве или совершенствовании изобретений, поступающих извне, занимает столь отдаленное место в рейтинге.

Для расчета уровня инновационности авторы индекса учитывают, в том числе, расходы на сектор НИОКР, производительность труда на одного работника, долю высокотехнологичных компаний в общем числе отечественных компаний, доступность высшего образования, численность работающих в секторе НИОКР или количество поданных патентных заявок. Южная Корея заняла первое место в Bloomberg Innovation Index набрав 87,38 балла из 100.

Если экономика будет инновационной, при прочих факторах, не меняющихся или не влияющих на развитие государства (вооруженные конфликты, санкции международного сообщества), то она будет двигаться в сторону более высокой производительности, а значит, и более высокого уровня жизни граждан. Кроме того, отечественная промышленность сможет создавать региональные и мировые бренды. Уровень благосостояния выражается в позиции государства на международной арене, а узнаваемость бренда влияет на восприятие государства иностранными сообществами, и в конечном счете - на способность единицы оказывать влияние за пределами своих границ, в соответствии с политикой власти.

\section{Список литературы}

1. I. Olivié, M. Gracia red., Elcano Global Presence. Report 2018, https://www.globalpresence.realinstitutoelcano.org/en/data/Global_Presence_2018.pdf [06.09.2019].

2. A. Runge, J. Runge, Słownik pojęć z geografii społeczno-ekonomicznej, Chorzów 2008, s. 292.

3. $\quad$ Ł. Osiński, EPO: liczba patentów przyznanych polskim wynalazcom wzrosła o 20 proc., http://naukawpolsce.pap.pl/aktualnosci/news\%2C28585\%2Cepo-liczba-patentow-przyznanych-polskim-wynalazcom-wzrosla-o-20-proc.html [07.09.2019].

4. М Хопей, Створення національного бренду на прикладі звіту «Бренд Польща Концепція», „Культурологічний Альманах” 2018, t. 9, с. 80-87.www.filosof.npu.edu.ua/images/ newifon/2018/vydannya/cult_alm_9.pdf [08.09.2019].

5. JB, TL, Najbardziej innowacyjne gospodarki świata - ranking państw z największą liczbą patentów, https://forsal.pl/artykuly/507008,najbardziej-innowacyjne-gospodarki-swiata-ranking-panstw-z-najwieksza-liczba-patentow.html [07.09.2019].

6. Ranking of the 10 countries who filed the most international patent applications in 2018, https://www.statista.com/statistics/256845/ranking-of-the-10-countries-who-filed-the-most-international-patent-applications/ [07.09.2019]. 
7. MP/DAP, Polska zaliczyła spadek w rankingu. Lider bez zmian, https://tvn24bis.pl/ze-swiata,75/bloomberg-innovation-index-ranking-najbardziej-innowacyjnych-panstw,903020.html [07.09.2019].

\section{Article text in English}

The Elcano Global Presence Index [1] model measures global presence, which is understood as the effective positioning in absolute terms of different countries outside their borders: economic, military and soft power. These areas were assigned point weights (in percentage terms) ranging from $20 \%$ to $40 \%$ of participation in the creation of a presence in the international arena. Besides, these categories are subdivided into 16 component indicators which form the ratings of economic, soft and military presence, if they are calculated correctly.

If you put them together, they will constitute the Elcano Global Presence Index 2018:

- the military presence (the share in the formation of the global state presence is $20 \%$ ) consists of only two elements: the number of servicemen (9\%) and military equipment (11\%).

- $\quad$ economic presence $(40 \%)$. Five indicators are qualified in this area: energy $(8 \%)$, basic goods $(6 \%)$, production $(8 \%)$, services $(8 \%)$, investments $(10 \%)$.

- the soft presence (40\%) includes the largest number of components, namely nine: migration $(4 \%)$, tourism $(4 \%)$, sport $(3 \%)$, culture $(5 \%)$, information $(5 \%)$, technology $(5 \%)$, science $(5 \%)$, education $(5 \%)$ and cooperation for development $(4 \%)$.

The technology is called "the number of patents filed in one or more countries", which in this report is synonymous with innovation and is based on two sources and three possibilities for understanding:

- Foreign-oriented patents: the number of related patent applications for the protection of the same invention filed in one or more foreign countries. The source of information is the statistical database of the World Intellectual Property Organization (WIPO).

However, the technology is defined in the following way in the case of European Union countries: - $\quad$ Foreign-oriented patents of all member states: the number of interrelated patent applications filed in one or more foreign countries to protect the same invention. The correction variable is a patent registered for each member state in other member states. Data alsocomes from WIPO databases.

- $\quad$ Number of patents registered with the European Patent Office (EPO) based on Eurostat data. 
Three sectors of the economy are classically distinguished [2]:

- $\quad$ agricultural (first) - covering agriculture, forestry, fishing and mining;

- $\quad$ industrial (second) - manufacturing industry and construction;

- $\quad$ services (third) - covering services in their broadest sense, such as the hotel, banking, hightech industry, etc.

Sometimes there's a fourth sector - mainly because of its importance for the information society of the 21 st century - as regards receiving, processing and providing information.

Therefore, it is necessary to note that according to this indicator the technology is not a part of the economic presence, but it's a soft component. The definition adopted by the Royal Institute of Elcano in Spain refers to the granting of patents and thus to the results of cooperation between lawyers and scientists from the R\&D sector. The economic presence is closely related to the second sector forming the gross domestic product (GDP), while the question about patents concerns other components of a soft presence, mainly the cooperation in the field of information, science and development.

The relevance of such a classification is confirmed by the example of the industries that submitted applications to the EPO. The largest number of patent applications in 2017 came from the sectors of medical technology, digital communications and computer technology. On the other hand, the largest increase in the number of applications was observed in the sectors of biotechnology, pharmaceuticals and measuring equipment [3].

Patents are the key to the development of any national economy - both developing and developed, which is based on modern technologies. Local technologies allow not only to develop competitive industry, get profit from license agreements, invest in foreign markets (foreign direct investment, FDI), but also to create national branding in the consciousness of foreign communities [4], and thus strengthen the presence of the state, which is "the influence of the entity outside its borders".

WIPO registered 164,000 patent applications in 2010 - inventions, utility models, etc. More than $27 \%$ of them were from the USA (which means more than 44,000 patents), 19.6\% from Japan and $10.7 \%$ from Germany [5]. While the United States of America remains the most innovative country in the world, it is also perceived as hegemonic, an absolute power in the international arena, but its dominance is diminishing in terms of the number of applications. The USA took first place among the countries that made requests to WIPO in 2018 (55,981 requests in 2018), surpassing China $(53,340$ requests) $[6]$ by only 2,641 .

It is interesting that the USA ranks 8th place only in terms of innovation, not the number of patents, while China is $21 \mathrm{st}$, but meanwhile, it takes the first place in the list by number of applications filed with WIPO. Bloomberg Innovation Index 2018 [7] is a rating that assesses the ability of economies to create innovation. That is why China takes such a remote place in the ranking as a developing country based on the reproduction or improvement of inventions coming from outside. 
In order to calculate the level of innovation, the authors of the index take into account, among other things, R\&D expenditures, labor productivity per employee, the share of high-tech companies in the total number of domestic companies, access to higher education, the number of employees in the R\&D sector or the number of patent applications filed. South Korea took first place in the Bloomberg Innovation Index and scored 87.38 points out of 100 .

If the economy is innovative, with other factors that do not change or do not affect the development of the state (armed conflicts, sanctions of the international community), it will move towards higher productivity, and therefore a higher standard of living for citizens. Besides, the domestic industry will be able to create regional and global brands. The level of wealth is expressed in the position of the state in the international arena, and brand recognition affects the perception of the state by foreign communities, and ultimately - the ability of the entity to have influence beyond its borders in accordance with the policy of the authorities.

\section{References}

1. I. Olivié, M. Gracia red., Elcano Global Presence. Report 2018, https://www.globalpresence.realinstitutoelcano.org/en/data/Global_Presence_2018.pdf [06.09.2019].

2. A. Runge, J. Runge, Słownik pojęć z geografii społeczno-ekonomicznej, Chorzów 2008, s. 292.

3. Ł. Osiński, EPO: liczba patentów przyznanych polskim wynalazcom wzrosła o 20 proc., http://naukawpolsce.pap.pl/aktualnosci/news\%2C28585\%2Cepo-liczba-patentow-przyznanych-polskim-wynalazcom-wzrosla-o-20-proc.html [07.09.2019 ].

4. М Хопей, Створення національного бренду на прикладі звіту «Бренд Польща Концепція», „Культурологічний Альманах” 2018, t. 9, с. 80-87.www.filosof.npu.edu.ua/images/ newifon/2018/vydannya/cult_alm_9.pdf [08.09.2019].

5. JB, TL, Najbardziej innowacyjne gospodarki świata - ranking państw z największą liczbą patentów, https://forsal.pl/artykuly/507008,najbardziej-innowacyjne-gospodarki-swiata-ranking-panstw-z-najwieksza-liczba-patentow.html [07.09.2019].

6. Ranking of the 10 countries who filed the most international patent applications in 2018, https://www.statista.com/statistics/256845/ranking-of-the-10-countries-who-filed-the-most-international-patent-applications/ [07.09.2019].

7. MP/DAP, Polska zaliczyła spadek w rankingu. Lider bez zmian, https://tvn24bis.pl/ze-swiata,75/bloomberg-innovation-index-ranking-najbardziej-innowacyjnych-panstw,903020.html [07.09.2019]. 
International Scientific and Practical Conference

ECONOMICS, POLITICS, LAW: TRENDS AND PROSPECTS

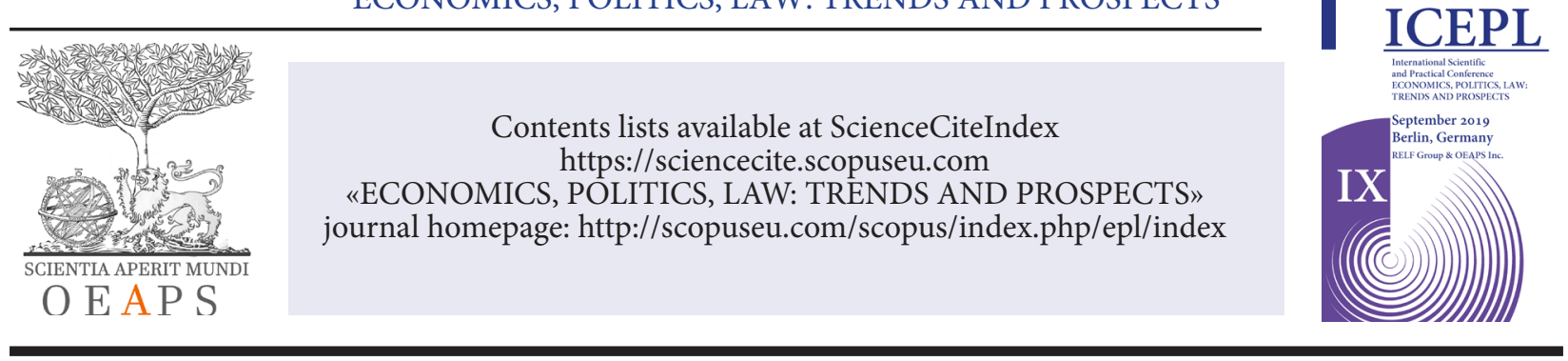

УДК 316

Проблема мультикультурной идентичности в современном мире
Кадиева Самира Абдулсамедовна
Доктор философии, научный сотрудник Института Философии
Национальной академии Наук Азербайджана, Азербайджан, Баку
samira-019@mail.ru

The problem of multicultural identity in the modern world

Kadiyeva Samira Abdulsamedovna

Doctor of philosophy, researcher, Institute of philosophy, National Academy of sciences of Azerbaijan, Azerbaijan, Baku

Аннотация: В статье анализируется проблема взаимодействия идентичностей в контексте мультикультурной глобализации. Автор отмечает то, что в условиях столкновения цивилизаций и различных ценностных доминант особую актуальность приобретают как нахождение человеком своего места в транскультурном обществе, так и формат и условия взаимодействия идентичностей. Указывается, что идея мультикультурной глобализации вытекает из простой формулы цивилизационного, культурного разнообразия, диалектики национальных и общечеловеческих ценностей в современном мире.

Ключевые слова: идентичность; ценности; глобализация; транскультурное общество; культурное разнообразие

Abstract: The article analyzes the problem of interaction of identities in the context of multicultural globalization. The author notes that in the context of the clash of civilizations and different value dominants, both the finding of a person's place in a transcultural society and the format and conditions of interaction of identities are of particular relevance. It is indicated that the idea of multicultural globalization follows from a simple formula of civilizational, cultural diversity, dialectics of national and universal values in the modern world.

Keywords: identity; values; globalization; transcultural society; cultural diversity

(C) 2019 The Author. Published by OEAPS Inc. This is an open access article under the CC BY-NC-ND license (http://creativecommons.org/licenses/by-nc-nd/4.0/) 
International Scientific and Practical Conference

ECONOMICS, POLITICS, LAW: TRENDS AND PROSPECTS

Современный мир представляет собой симбиоз различных направлений, школ, течений, идеологий, культурных коммуникаций и технологий мысли. Казалось бы, открытие границ, пресловутый «конец истории», а вследза нимпредполагаемая, апорой и открыто проявляющая себя тенденция «конца географии» выдвигает непременным условием человеческого сосуществования принятие общих нормативов со-жития, взаимодействия, выражаемых посредством культурного взаимопроникновения, соотношения «чужого, другого» и «своего». Идея мультикультурной глобализации вытекает из простой формулы цивилизационного, культурного разнообразия, диалектики национальных и общечеловеческих ценностей, как смысловой доминанты, объединяющего начала, соотносимого с любым из потенциальных субъектов культурного диалога. Именно культура становится тем основным ресурсом, вовне и внутри которой намечаются ориентиры будущего мироустройства и, что самое важное, вызревают модели восприятия и приятия «инаковости». В условиях глобализационной парадигмы, когда глобальность равнозначна единству локальных организмов, сама идея их сосуществования становится исторической традицией, которая допустимо и оправдано формулирует экзистенцию вселенского общежития. Именно данная модель взаимодействия становится востребованной, когда речь заходит об основах выживания «человейника» и его благоустройства.

Проблемы общецивилизационного развития и со-жития, актуализированные в свете сегодняшних процессов, затрагивались еще в трудах М. Вебера, Э.Дюркгейма, К.Маркса, Т.Парсонса, О.Конта и др. Великие географические открытия, колониализм, мировые войны, всемирный рынок, капиталистическая система хозяйствования - все это в большей или меньшей степени характеризует множественный характер человеческого взаимодействия, единство исторической судьбы, расширение географического и духовного пространств. [4, с.11-12] УГлубляющая и растущая связь между локальными ячейками посредством письменности, временных символов, форм и категорий мышления приводила к более интенсивному налаживанию контактов и взаимодействию между людьми, что особенно проявилось в конце прошлого тысячелетия, в так называемое «осевое время» (появление мировых культур, религий и цивилизаций). В философской и религиозной литературе того времени и позже обосновывается идея глобальности мира, общей судьбы человечества (греческая философская литература, конфуцианство, джайнизм, иудаизм, христианство, ислам). Движимые навстречу друг другу народы, расширение уровней и масштабов их взаимодействия, проявляющееся в культурной, экономической, политической, мировоззренческой плоскости до пределов принимаемой ими ойкумены-обосновывало идею единства человечества, наличие философской модели глобального общежития.[2, с. 69-83] Если схематично отобразить общественную конфигурацию на начальных этапах объединения человечества, то налицо интегративная составляющая процессов взаимодействия между локальными структурами, культурными социумами. Вследствие этих процессов, основанных на соперничестве, происходила реконфигурация политического и культурного пространства. Различные периоды исторического прошлого, в которых наблюдались процессы миграции, 
International Scientific and Practical Conference

ECONOMICS, POLITICS, LAW: TRENDS AND PROSPECTS

переселений, смена общественных формаций, зарождение государственных образований, эволюция их до национального государства характеризовались потребностью расширения географического пространства и освоения новых ресурсов, которым сопутствовала военная экспансия. Овладение новыми территориями и связями проходило путем закрепления универсальных параметров общежития, результатом которых выступала относительно гомогенная социальная структура (племена, этносы и нации). Взаимодействие культур выражало себя в различных процессах, как то заимствование, ассимиляция, аккультурация, сопровождалось порой насильственным внедрением чуждых символов и систем. [1, с.32-54] Положительная динамика просматривалась в приобщении к общим нравственным ценностям, мировоззренческим идеям; в сближении народов, образовавших новый пласт общественной системы. Т.е. объективная наполненность культурного сосуществования по определению зиждется на общечеловеческом концепте, упирается в идею антропобиологического единства.

Примечательно, что в русле такого дискурса можно отметить немало примеров смещения цивилизационного вектора, отмеченного экономическим, политическим и культурным доминированием, в силу чего изменениям подвергались различные общества, государства, цивилизации $[5$, p. 1$]$. В свою очередь, доминирование одной из цивилизаций на некоей поворотной исторической стадии проявлялось особенно зримо. [5, p. 123-127] В то время, как нынешнее мировое сообщество, согласно определяющей тенденции развития, движется к состоянию генерализации, гомогенизации, зарождаются и все больше проявляют себя очаги локальных настроений, выпадов, имеющих целью сохранить и отстоять национальнокультурную идентичность, свой тип социальности. Понятно, что в подобном срезе модель взаимоприемлемого общежития находит выражение в тенденции сближения и приятия различных цивилизаций, национальных государств и этносов, систем и структур в пределах единого мирового пространства, в многообразии культурных моделей коммуникации. [3. с .6] Мультикультурализм зиждется на основных постулатах классического равноправия «своего» и «чужого» («другого»), соотнесенных с заявками на толерантность, уважение и понимание различий, ответственности каждого за эффективное разрешение проблем современности в период социокультурных, экономических, политических, и, что особенно важно, экзистенциональных разломов, гармонизации межкультурных и межцивилизационных контактов.Концепция мультикультурализма представлена несколькими политическими дискурсами, а следовательно, и дискуссантами, согласно которым она воспринималась и как смена базовой парадигмы мироустройства с этнокультурной гомогенности на мультикультуральное множество, и как государственная политика, способ разрешения общественно-политических проблем, так называемая политкорректность, и как особое проявление западной культуры конца двадцатого столетия. На наш взгляд, в свете текущих процессов, при наличии острых глобальных проблем, таких как ксенофобия, национализм, терроризм и сепаратизм, а также процессов, сопровождающих мировые трансформации (миграция, криминализация, девиация), особенно явственно обозначается актуальность понимания и формулирования перспектив цивилизационного развития, самой идеи равноправного со-участия и со-жития различных и отличных друг от друга идентичностей. 
International Scientific and Practical Conference

ECONOMICS, POLITICS, LAW: TRENDS AND PROSPECTS

Этот социальный запрос является философским дискурсом будущего, общей гуманитарной рефлексией.

Время недвусмысленно указывает на необходимость нахождения общего эквивалента понятию «человечество», на обновление исторической традиции. Люди, под давлением социальных трансформаций, стали игнорировать сам факт того, что, несмотря на все различия, на множественность культурных кодов, моделей коммуникации, этносов и цивилизаций, несмотря на все наше разнообразие и многообразие, мы - носители общечеловеческого штампа, имеющие возможность адаптироваться, договариваться, обращаться к общечеловеческим морально-этическим нормам, духовным ценностям, которыми каждый из нас эпистемологически измеряет «себя» по отношению к «другому». И если существует понимание «индивидуума», то и понимание человека как социального феномена должно быть созвучно ему, не вызывать явлений отторжения и противопоставления «себя» «чужому». Напротив, понимание общего в проекции единичного выступает определяющим и организующим, солидаризирующим звеном. Планетарная цивилизация представляет собой единение традиций, культур; человечество - единение идентичностей, их общность; будущее же мироустройства предполагает единение позиций в общем для всех гуманитарном миропроекте, так называемую культуру диалога, понимания и приятия.

\section{Список литературы}

1. Бенхабиб С. Притязания культуры: Равенство и разнообразие в глобальную эру. (пер: с англ. под ред. В. И. Иноземцева). М.: Логос. 2003. 350 с.

2. Гранин Ю. Д. Глобализация и национализм: история и современность. Социальнофилософский анализ. Саабрюкен : LAP LAMBERT, 2011.

3.Пантин В.И. Циклы и волны глобальной истории. Глобализация в историческом измерении. М. 2003.

4.Покровская Н. Н. Мультикультурализм как путь глобализации. Личность и культура. 2001. № 5-6.

5. Frank A. G. ReOrient: Global Economy in the Asian Age. Berkeley, LA, 1998.

\section{The text of the article in English}

The modern world is a symbiosis of various directions, schools, trends, ideologies, cultural communications and technologies of thought. It would seem that the opening of borders, the notorious "end of history", and after it the alleged, and sometimes openly manifesting tendency of the "end of geography", sets forth the adoption of common standards for coexistence, interaction, expressed through cultural interpenetration, the correlation "stranger, another "and" his ". The idea of multicultural globalization follows from a simple formula of civilizational, cultural diversity, the dialectic of national and universal values, as a semantic dominant, uniting principles that are correlated with any of the potential subjects of cultural dialogue. It is culture that becomes the main resource, outside and inside of which the guidelines of the future world order are outlined and, 
International Scientific and Practical Conference

ECONOMICS, POLITICS, LAW: TRENDS AND PROSPECTS

most importantly, the models of perception and acceptance of "otherness" mature. In the context of the globalization paradigm, when globality is equivalent to the unity of local organisms, the very idea of their coexistence becomes a historical tradition that admits and justifies the existence of a universal hostel. It is this model of interaction that becomes popular when it comes to the basics of survival of the "humane" and its improvement.

The problems of civilization development and co-existence, actualized in the light of today's processes, were touched upon in the writings of M. Weber, E. Durkheim, K. Marx, T. Parsons, O. Comte and others. Great geographical discoveries, colonialism, world wars, world the market, the capitalist economic system - all this to a greater or lesser extent characterizes the multiple nature of human interaction, the unity of historical destiny, the expansion of geographical and spiritual spaces. [4, pp. 11-12] The deepening and growing connection between local cells through writing, temporary symbols, forms and categories of thinking led to more intensive networking and interaction between people, which was especially evident at the end of the last millennium, in the so-called "axial time "(the emergence of world cultures, religions and civilizations). The philosophical and religious literature of that time and later substantiated the idea of a global world, the common fate of mankind (Greek philosophical literature, Confucianism, Jainism, Judaism, Christianity, Islam). Moving towards each other, the expansion of the levels and scale of their interaction, which manifests itself in a cultural, economic, political, worldview plane to the limits of the ecumenical community they accept, substantiated the idea of the unity of mankind, the existence of a philosophical model of global community. [2, p. 69-83] If we schematically reflect the social configuration at the initial stages of the unification of mankind, then there is an integrative component of the processes of interaction between local structures and cultural societies. As a result of these rivalry-based processes, a reconfiguration of the political and cultural space took place. The various periods of the historical past in which the processes of migration, resettlement, the change of social formations, the emergence of state formations, their evolution to a national state were observed were characterized by the need to expand the geographical space and the development of new resources, which were accompanied by military expansion. The mastery of new territories and ties took place by consolidating the universal parameters of the hostel, the result of which was a relatively homogeneous social structure (tribes, ethnic groups and nations). The interaction of cultures expressed itself in various processes, such as borrowing, assimilation, acculturation, sometimes accompanied by the forcible introduction of alien symbols and systems. [1, p. 32-54] Positive dynamics were seen in the introduction to common moral values, ideological ideas; in the rapprochement of the peoples who formed a new layer of the social system. Those. the objective fulfillment of cultural coexistence, by definition, is based on the universal concept, rests on the idea of anthropobiological unity.

It is noteworthy that in the context of such a discourse, there are many examples of the displacement of the civilizational vector, marked by economic, political and cultural dominance, as a result of which various societies, states, civilizations underwent changes [5, p. one]. In turn, the dominance of one of the civilizations at a certain turning historical stage was manifested especially visibly. [5, p. 123-127] At the same time, as the current world community, according to the decisive development 
trend, is moving towards a state of generalization, homogenization, centers of local moods, attacks, which aim to preserve and defend national-cultural identity, their own type of sociality are emerging and are increasingly manifesting themselves. . It is clear that in this context, the model of mutually acceptable hostel finds expression in the tendency of rapprochement and acceptance of various civilizations, national states and ethnic groups, systems and structures within a single world space, in the diversity of cultural communication models. [3. p .6] Multiculturalism is based on the basic tenets of the classical equality of "one's" and "another's" ("other"), correlated with applications for tolerance, respect and understanding of the differences, responsibility of everyone for the effective resolution of the problems of our time in the period of sociocultural, economic, political, and, most importantly, existential faults, harmonization of intercultural and intercivilizational contacts. The concept of multiculturalism is represented by several political discourses, and, therefore, is discussed according to which it was perceived both as a change in the basic paradigm of the world order from ethnocultural homogeneity to a multicultural set, and as state policy, a way of resolving socio-political problems, the so-called political correctness, and as a special manifestation of Western culture of the late twentieth century. In our opinion, in the light of current processes, in the presence of acute global problems, such as xenophobia, nationalism, terrorism and separatism, as well as processes accompanying world transformations (migration, criminalization, deviation), the urgency of understanding and formulating the prospects of civilizational development is especially clearly indicated, the very idea of equal co-participation and co-existence of different and distinct identities. This social request is the philosophical discourse of the future, a general humanitarian reflection.

Time clearly indicates the need to find a common equivalent to the concept of "humanity", to update the historical tradition. People, under the pressure of social transformations, began to ignore the very fact that, despite all the differences, the multiplicity of cultural codes, communication models, ethnic groups and civilizations, despite all our diversity and diversity, we are carriers of a universal stamp that have the ability to adapt, to negotiate, turn to universal human moral and ethical standards, spiritual values, with which each of us epistemologically measures "ourselves" in relation to the "other". And if there is an understanding of the "individual", then the understanding of man as a social phenomenon should be consonant with him, not cause rejection and opposition of "self" - "alien". On the contrary, the understanding of the general in the projection of the individual acts as the determining and organizing, solidarity link. Planetary civilization is a unity of traditions, cultures; humanity - the unity of identities, their community; the future of the world order presupposes a unification of positions in the humanitarian world project common to all, the so-called culture of dialogue, understanding and acceptance.

\section{References}

1. Benhabib S. Claims of culture: Equality and diversity in the global era. (transl.: from English. under the editorship of V.I. Inozemtsev). M .: Logos. $2003.350 \mathrm{~s}$.

2. Granin Yu. D. Globalization and nationalism: history and modernity. Socio-philosophical analysis. Saabrucken: LAP LAMBERT, 2011. 
International Scientific and Practical Conference ECONOMICS, POLITICS, LAW: TRENDS AND PROSPECTS

3.Pantin V.I. Cycles and waves of global history. Globalization in the historical dimension. M. 2003.

4. Pokrovskaya N. N. Multiculturalism as a way of globalization. Personality and culture. 2001. No. 5-6.

5. Frank AG ReOrient: Global Economy in the Asian Age. Berkeley, LA, 1998. 
International Scientific and Practical Conference

ECONOMICS, POLITICS, LAW: TRENDS AND PROSPECTS

Contents lists available at ScienceCiteIndex https://sciencecite.scopuseu.com «ECONOMICS, POLITICS, LAW: TRENDS AND PROSPECTS»

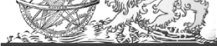
SCIENTIA APERIT MUND journal homepage: http://scopuseu.com/scopus/index.php/epl/index

O EAPS

\title{
Маркетинговый анализ рынка бытовой техники в условиях инновационного развития экономики
}

Ржесик Константин Адольфович кандидат технических наук, профессор, заведующий кафедрой холодильной и торговой техники имени В.В. Осокина ГО ВПО «Донеикий национальный университет экономики и торговли имени Михаила Туган-Барановского», г. Донеик marketing.texnika@bk.ru

\section{Marketing analysis of the market of household appliances in terms of innovative development of the economy}

\author{
Rzhesik K.A. \\ candidate of technical sciences, professor, \\ head of the department of refrigeration and commercial equipment \\ named after V.V. Osokin \\ SO HPE «Donetsk National University of Economics and Trade \\ named after Mykhayilo Tugan-Baranovsky», Donetsk
}

\begin{abstract}
Аннотация: В статье рассмотрены особенности осуществления маркетингового анализа как основного этапа маркетингового исследования на рынке бытовой техники в условиях инновационного развития экономики, определены основные этапы маркетингового анализа рынка бытовой техники, систематизированы методы проведения маркетингового анализа рынка бытовой техники. Определены задачи инновационной политики, которые направлены на стимулирование инклюзивного роста и поддержку исследований на основе маркетингового анализа на рынке бытовой техники, направленных на решение основных социальных и экономических вопросов в усовиях инновационного развития экономики.
\end{abstract}

(c) 2019 The Author. Published by OEAPS Inc. This is an open access article under the CC BY-NC-ND license (http://creativecommons.org/licenses/by-nc-nd/4.0/) 
International Scientific and Practical Conference

ECONOMICS, POLITICS, LAW: TRENDS AND PROSPECTS

Abstract: The article describes the features of marketing analysis as the main stage of marketing research in the market of household appliances in the conditions of innovative development of the economy, the main stages of marketing analysis of the market of household appliances, systematized methods of marketing analysis of the market of household appliances. The tasks of innovation policy aimed at stimulating inclusive growth and supporting research on the basis of marketing analysis in the market of household appliances aimed at addressing the main social and economic issues in the innovative development of the economy.

Ключевые слова: маркетинговый анализ, рынок бытовой техники, маркетинг инноваций, инновационное развитие экономики, управление маркетинговой деятельностью.

Key words: marketing analysis, household appliances market, innovation marketing, innovative economic development, marketing management.

Постановка проблемы. Недавний глобальный экономический кризис создает проблемы, которые являются еще более значительными и вынуждают производственные предприятия на рынке бытовой техники быть более творческими и амбициозными в поисках новых рынков производства и сбыта. Очевидно, что способность предприятий идентифицировать внутренние возможности и отличать их от конкурентов имеет решающее значение. Для поддержания своих конкурентных преимуществ предприятия должны обновлять свою ресурсную базу по мере изменения окружающей среды. Инновации играют решающую роль в будущем предприятий, следуя быстрым темпам эволюции рынков и, далее, будучи в состоянии адаптироваться к радикальным технологическим изменениям. Неудивительно, что управление инновациями, основанное на результатах маркетингового анализа современного состояния рынка бытовой техники в условиях инновационного развития экономики сегодня является одной из самых сложных задач [1].

Различные теоретические и практические аспекты особенностей научных исследований на основе маркетингового анализа широко представлены в работах зарубежных и отечественных ученых, таких как Т. Браун, Д. Аакер, С. Антхольт, Т. Гэд, М. Данн, Е. Азарян, В. Анурин, И. Акулич, Е. Анохин, И. Беляевский, Е. Ванчикова, Е. Кузьмина, А. Коротков, С. Божук.

Основная исследовательская задача - охарактеризовать инновационную политику и определить ее роль в конкурентной борьбе на рынке бытовой техники, более детально исследовать потенциальное дифференциальное влияние модели технологического инновационного потенциала на устойчивое конкурентное преимущество в промышленности.

Цели исследования. Цель данного исследования - внести вклад в теоретические знания и изучить особенности осуществления маркетингового анализа как основного этапа маркетингового исследования на рынке бытовой техники. Маркетинговый анализ на рынке 
бытовой техники - это существенный момент в работе менеджера по маркетингу. Подробный анализ дает возможность оперативно определять незанятые рыночные ниши, выбрать максимально подходящий целевой рынок, лучше осознать потребительские потребности на рынке бытовой техники. Объект исследования - индустрия бытовой техники, которая является прототипом высокотехнологичной отрасли. В последнее время в связи с ростом глобальной конкуренции и глобальным экономическим кризисом появились новые, более динамичные перспективы стратегического управления. Результаты маркетингового анализа необходимы при определении перспектив в области стратегического управления инновациями на рынке бытовой техники.

Результаты исследования и их обсуждение. На начальном этапе маркетингового анализа на рынке бытовой техники следует конкретизировать цели исследования рынка. Необходимо прояснить следующие составляющие: продукция фирмы: анализ развития рынка и доли продукции фирмы в сегменте; структура рынка бытовой техники: анализ конъюнктуры и маркетинговой емкости рынка, оценка рыночных тенденций; потребитель: анализ спроса, основных потребностей на рынке, пристальное маркетинговое изучение поведения и ожиданий целевой аудитории; целевой сегмент: анализ перспективности сегментов рынка для выбора поля деятельности; свободные ниши: маркетинговый анализ рыночных сегментов для выявления свободных рыночных ниш и новых источников сбыта; соперники: анализ деятельности соперников для выявления конкурентного превосходства продукции и поиска слабых мест фирмы; цены: маркетинговый анализ ценовых позиций соперников, а также нынешней ценовой структуры в отрасли.

Укрупненные стадии маркетингового исследования рынка бытовой техники заключаются в следующем.

1. Изучение конъюнктуры рынка, его сегментация и выявление наиболее значимых сегментов.

2. Маркетинговое исследование объема, динамики и потенциала развития рынка.

3. Изучение цен и общий экономический анализ рынка.

4. Конкурентный анализ.

5. Исследование рекламных методов, способов продвижения и поддержки продукции.

6. Изучение структуры распределения или дистрибуции товара на рынке.

7. Определение ключевых рыночных и потребительских тенденций.

8. Исследование спроса, главных потребностей и нюансов потребительского поведения.

Маркетинговые исследования рынка сбыта на рынке бытовой техники включают в себя поиск наиболее эффективного сочетания используемых методов и форм реализации товаров, их сильных и слабых сторон, принадлежности к сегменту рынка либо региону продаж [1]. Способы сбора сведений при осуществлении маркетинговых исследований можно разделить на две группы: качественные и количественные. Количественный 
анализ рынка чаще всего связывают с организацией разных опросов. Они базируются на применении структурированных вопросов закрытого вида. Ответы дает большое количество респондентов. Качественный маркетинговый анализ рынка состоит из сбора, изучения и толкования сведений с помощью наблюдения за тем, как люди ведут себя и что при этом произносят. Основные этапы маркетингового анализа рынка бытовой техники представлены на рисунке 1.

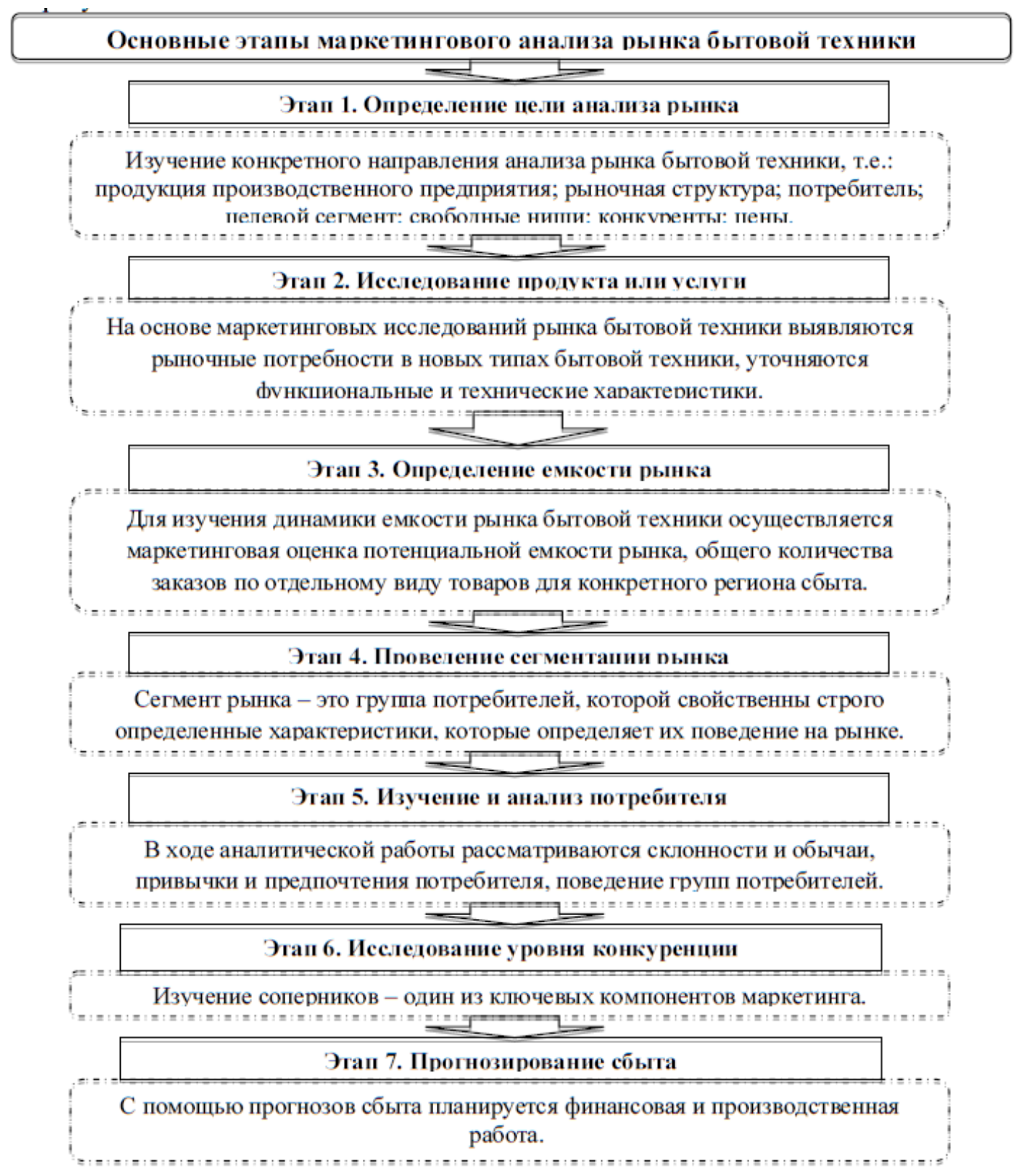

Рисунок 1. Основные этапы маркетингового анализа рынка бытовой техники 
На следующем этапе изучения особенностей осуществления маркетингового анализа рынка бытовой техники, рассмотрим методы, с помощью которых проводится данный анализ (таблица 1).

Таблица 1. Метод проведения маркетингового анализа рынка бытовой техники.

\begin{tabular}{|c|c|c|}
\hline № ח/п & Метод & Свойства метода и его специфика \\
\hline 1 & Фокус-группы. & $\begin{array}{l}\text { Круглый стол либо дискуссия, где идет разговор на } \\
\text { определенную тему. Участие принимает целевая группа } \\
\text { потребителей. На этом мероприятии присутствует } \\
\text { модератор, который ведет беседу по определенному списку } \\
\text { вопросов. Это - качественный метод маркетингового } \\
\text { исследования рынка, он полезен для понимания причин } \\
\text { поведения. Фокус-группы помогают сформулировать } \\
\text { гипотезы, изучить скрытые мотивы клиентов. }\end{array}$ \\
\hline 2 & Опросы. & $\begin{array}{l}\text { Подразумевают опрос целевого рынка по строгой анкете. } \\
\text { По величине бывают как маленькими, так и большими. В } \\
\text { маркетинговом опросе большое значение имеет выборка. } \\
\text { Чем она крупнее, тем более четкий и действительный итог } \\
\text { будет получен. Это - количественный маркетинговый } \\
\text { метод. Он применяется, когда нужно получить конкретные } \\
\text { показатели по определенным вопросам. }\end{array}$ \\
\hline 3 & Наблюдение. & $\begin{array}{l}\text { Мониторинг поведения представителя целевой аудитории } \\
\text { в обычной среде (допустим, видеосъемка в магазине). } \\
\text { Относится к качественным маркетинговым методам } \\
\text { изучения. }\end{array}$ \\
\hline 4 & $\begin{array}{l}\text { Эксперименты } \\
\text { либо полевые } \\
\text { исследования. }\end{array}$ & $\begin{array}{l}\text { Относятся к количественным маркетинговым методам. } \\
\text { Дают возможность проверить какие-либо предположения и } \\
\text { альтернативы в реальной жизни. }\end{array}$ \\
\hline 5 & $\begin{array}{c}\text { Глубинные } \\
\text { интервью. }\end{array}$ & $\begin{array}{l}\text { Разговор с одним представителем целевой аудитории по } \\
\text { конкретному списку открытых вопросов. Дают возможность } \\
\text { подробно разобраться в теме и сформировать гипотезы. } \\
\text { Относятся к качественным маркетинговым способам. }\end{array}$ \\
\hline
\end{tabular}


При проведении анализа рынка бытовой техники можно назвать группу аналитикопрогностических способов проведения маркетингового исследования, такие как: теория вероятности, линейное планирование; сетевое планирование; методы деловых игр; экономико-математическое моделирование; способы экспертного оценивания; экономикостатистические методы.

Экономический рост происходит потому, что люди имеют в своем распоряжении либо больше ресурсов, либо лучшие идеи для превращения ресурсов в товары и услуги. Увеличение ресурсов само по себе не может стимулировать устойчивый экономический рост. Природные ресурсы ограничены в ограниченном мире, и хотя образование может значительно повысить производительность человеческих ресурсов, такие достижения ограничиваются продолжительностью человеческой жизни. Действительно, по оценкам Нобелевского лауреата Роберта Солоу, менее половины экономического роста США приходится на увеличение ресурсов. Львиная доля роста обусловлена техническим прогрессом [1].

Помимо того, что научно-технические знания играют центральную роль в устойчивом росте уровня доходов, они обусловили ряд важных экономических тенденций. В производстве технологический прогресс был основной силой, лежащей в основе перехода от ручных к механизированным методам производства, от природных к синтетическим материалам, от человека и животных к минеральным источникам энергии и от сырого труда к высокообразованным и специализированным рабочим, то есть от технологий к инновациям. Внедрение инноваций часто приводит к расширению рынков. Более крупные рынки необходимы для того, чтобы позволить рабочим и фирмам сконцентрироваться на узкоспециализированной деятельности и повысить отдачу от инноваций, связанных с инвестициями в специализированные знания или оборудование.

Инновации в области промышленности привели соответственно к резким изменениям в организации экономической деятельности, перемещению производства из дома, увеличению среднего размера предприятий, концентрации производства в городах и увеличению географических масштабов торговли и роли международных сделок в местной и национальной экономике.

Научные исследования часто генерируют идеи, которые ценны во многих сферах бизнеса. Из-за этого фундаментальные исследования поддерживаются государственными средствами, а новые открытия широко распространяются. В более узких и прикладных областях знаний исследования поддерживаются посредством защиты прав интеллектуальной собственности. Они предоставляют изобретателям временную монополию на использование своих идей, позволяя им окупить расходы на исследования. Права интеллектуальной собственности пытаются уравновесить стремление вознаграждать успешные исследования социальными выгодами, получаемыми от конкурентных рынков и широкого распространения хороших 
идей. Помимо прав интеллектуальной собственности, для успешного проведения государственных и частных исследований необходима образованная рабочая сила. Доступ к крупным рынкам позволяет фирмам распределять постоянные затраты на изобретение новой идеи на большое количество единиц продукции, повышая отдачу от ресурсов, выделяемых на исследования. Для стран, не находящихся на технологической границе, технический прогресс в большей степени обусловлен имитацией, чем инновациями. Многие технологии должны быть адаптированы к местным условиям, включая квалификацию рабочей силы, нормативную среду, наличие жизненно важных ресурсов и культурные различия [2].

Открытость международным рынкам и эффективная правовая система, защищающая права иностранных инвесторов, играют важную роль в привлечении многонациональных компаний, использующих передовые технологии. Во многих развивающихся странах, включая Китай и Индию, наблюдался заметный рост темпов роста непосредственно после открытия доступа к международной торговле и иностранным инвестициям.

С другой стороны, международная торговля может привести к тому, что развивающиеся страны будут специализироваться на менее технологически динамичных видах экономической деятельности, таких, как сельское хозяйство и горнодобывающая промышленность, а иностранные инвестиции в этих областях могут мало что сделать для содействия продолжающейся передаче технологий [3].

Поскольку внедрение новой технологии, как правило, порождает как победителей, так и проигравших, международная передача технологии может также столкнуться с преднамеренным и хорошо организованным противодействием, конкурентной борьбе. Новым технологиям часто противостоят доиндустриальные элиты, которые боятся потери лидерства перед новым промышленным классом, существующие отрасли, которые инвестируются в старые технологии, и профсоюзы, которые боятся потери рабочих мест.

Хотя технический прогресс в долгосрочной перспективе повышает средние доходы, издержки и выгоды новой технологии, как правило, распределяются неравномерно, что создает ряд проблем для стран, переживающих быстрый технический прогресс. Внедрение новых товаров и процессов часто напрямую конкурирует с существующими экономическими фирмами, заставляя их адаптироваться или быть вытесненными из бизнеса, процесс, называемый креативным разрушением по словам экономиста Йозефа Шумпетера [2]. Появление персонального компьютера в 1980-х годах спровоцировало серьезный кризис в IBM, ведущем производителе мэйнфреймов.

Оперативная модель влияния инновационных возможностей на конкурентное преимущество и эффективность бизнеса вытекает из теоретического фона и показывает наше восприятие того, как технологические инновационные возможности, конкурентное преимущество и 
International Scientific and Practical Conference

ECONOMICS, POLITICS, LAW: TRENDS AND PROSPECTS

эффективность предприятия могут быть взаимосвязаны. Очевидно, что технологический инновационный потенциал редко возникает в результате деятельности одного субъекта хозяйствования. Соответственно, технологический инновационный потенциал является результатом внутренних и внешних источников.

Конкуренция между диверсифицированными компаниями происходит прежде всего на уровне отдельных стратегических бизнес-единиц. Поэтому технологически инновационные возможности фирмы должны анализироваться не только на корпоративном уровне, но и на уровне каждой стратегической бизнес-единицы. С этой точки зрения используются принципы портфельного анализа, как одного из инструментов маркетингового анализа. Оцениваются знания и навыки, необходимые для каждой стратегической технологической единицы, а затем необходимо переходить на уровень всего предприятия, где должны быть определены общие технологические знания и навыки. Поэтому инновационно-технический потенциал следует разделить на направления соответствующей деятельности и навыки, которые, как правило, поддерживают одно и то же стратегическое направление.

Игроки на рынке бытовой техники компаниий LG, Samsung, Электролюкс, Вирпул корпорации, концерна Siemens, Уолтон группы имеют все условия для перспектив развития рынка бытовой техники. В связи с растущим спросом на энергоэффективную продукцию, эти участники отрасли активно разрабатывают устройства с большим количеством функций, таких как, например, определение температуры. НИОКР также широко распространены на рынке бытовых электроприборов. Государственные органы осуществляют различные программы, такие, как программа действий в области домашней энергетики, в целях предоставления энергоэффективных устройств домашним хозяйствам с низким уровнем дохода. В странах, ориентированных на минимизацию уровней выбросов углерода, ряд программ и стратегий стимулируют инновации в области разработки продуктов [4].

Производители бытовой техники инвестируют больше всего в свои исследования и разработки бизнеса и сосредоточение внимания на эффективной разработке продукции. Например, современные печи и другие устройства для приготовления пищи обеспечивают передовые сенсорные элементы управления и ЖК-дисплеи с улучшенными эстетическими значениями и функциями управления. Кроме того, по мере расширения возможностей подключения интернет вещей (IоT) позволяет получать доступ к устройствам в режиме реального времени даже без физического присутствия пользователя. Это привело к легкому и эффективному использованию этих продуктов.

Инновации важны на всех этапах развития; в частности, создание и распространение технологий имеют важное значение для экономического роста и благосостояния во всех странах. Различные виды инноваций играют определенную роль на различных этапах (например, на более ранних этапах инкрементные инновации часто связаны с внедрением 
иностранных технологий). Появляются возможности для успешного проведения инновационных экспериментов и создания потенциально иной основы для развития. В частности, эти возможности обусловлены развитием информационно-коммуникационных технологий, развитием глобальных производственно-сбытовых цепочек, повышением роли некоторых развивающихся стран в глобальной инновационной системе, ростом экономики, основанной на услугах, и большей открытостью для торговли и прямых иностранных инвестиций. Сегодня ключевой задачей инновационной политики в развивающихся странах является стимулирование инклюзивного роста и поддержка исследований на основе маркетингового анализа, направленных на решение основных социальных проблем.

Различные виды инноваций могут играть различную роль на различных этапах развития. На более ранних этапах постепенные инновации часто связаны с внедрением иностранных технологий, а социальные инновации могут повысить эффективность бизнеса и государственных услуг. Инновационная деятельность, основанная на высоких технологиях и НИОКР, имеет большее значение на более поздних этапах развития и в большинстве случаев на передовых предприятиях в развивающихся странах, когда она является фактором конкурентоспособности и обучения.

Ряд стран с формирующейся рыночной экономикой, в частности Китай, стали важными участниками глобальной инновационной системы. Есть свидетельства того, что НИОКР сыграли ключевую роль в взлете азиатских экономик, таких как Китай, Индия и Корея. Более того, многие страны с формирующейся рыночной экономикой имеют отрасли или фирмы, которые находятся на переднем крае технологии и нуждаются в инновациях, чтобы конкурировать.

Инновации могут помочь решить проблему неравенства в развивающихся странах. Хотя инновации и рост играют центральную роль в решении социальных проблем, улучшении экономических показателей и создании рабочих мест, их воздействие не обязательно является «социально» инклюзивным, поскольку они могут усиливать неравенство в доходах и возможностях различных групп общества. Большинство бедного населения мира проживает в странах со средним уровнем дохода, где неравенство в доходах и возможностях поразительно неудобными. Реалии во многих развивающихся странах таковы, что небольшая часть населения имеет доступ к более широким ресурсам и возможностям, в то время как большая группа не имеет доступа к основным ресурсам. Во многих правительственных программах первоочередное внимание уделяется социально инклюзивному развитию, поскольку высокий уровень неравенства может негативно сказаться на росте.

Инновационная динамика и политика оказывают влияние на «инклюзивность в промышленности», которая заключается в том, насколько фирмы отличаются в своих инновациях и производительности. Инновационный потенциал многих развивающихся 
International Scientific and Practical Conference

ECONOMICS, POLITICS, LAW: TRENDS AND PROSPECTS

стран экономической структуры характеризуются как потенциал ведущих предприятий, отраслей, научно-исследовательских институтов или университетов, которые сосуществуют с группой слабо работающих предприятий или учреждений и значительного неформального сектора экономики. Промышленная инклюзивность оказывает потенциально важное воздействие на социальную инклюзивность. Кроме того, важным аспектом этого неравенства является «территориальная инклюзивность» - географические аспекты промышленного и социального неравенства [5].

Хорошо продуманная инновационная политика в основу которой заложены результаты маркетингового анализа рынка бытовой техники направлена на использование возможностей для развития с учетом экономических и социальных реалий в различных регионах страны, будь то столица или отдаленная сельская местность, путем обеспечения доступа населения и фирм к необходимым общественным благам и услугам.

Выводы. Реализация предложенных мероприятий в отрасли промышленного производства позволит значительно повысить уровень инновационной активности отечественных производственных предприятий, стабилизировать ускоренный процесс обновления производства, эффективно использовать внутренние и привлеченные внешние инвестиции на инновационную деятельность.

С точки зрения важности изучаемых объектов исследования, а именно маркетинга инноваций в производстве, эффективности его внедрения и использования в производственной среде, необходимо в дальнейших научных исследованиях охарактеризовать этапы внедрения инновационных товаров (продукции) в производственную сферу на основе маркетингового подхода и описать характер исследовательских работ, на этапе проведения маркетинговых исследований, что является важным при формировании стратегии маркетинга и внедрения инноваций в производство.

\section{Список литературы}

1. Нобелевская премия по экономике 1987. Роберт Солоу (1924). Электронный ресурс. Режим доступа: http://nobeliat.ru/laureat.php?id=439

2. Федеральная служба статистики Российской Федерации [Электронный ресурс]. Режим доступа: https://fedstat.ru/organizations/

3. Technological innovation capabilities as a source of competitive advantage: A case study from the home appliance industry. Электронный ресурс, Режим доступа: https:/www.researchgate.net/ publication/268505043 Technological_innovation_capabilities_as a source of_competitive advantage A case study from the home appliance industry

4. Electric Household Appliances Market Size By Product . Электронный ресурс. Режим доступа: https://www.gminsights.com/industry-analysis/electric-household-appliances-market 
International Scientific and Practical Conference

ECONOMICS, POLITICS, LAW: TRENDS AND PROSPECTS

5. Бусыгин К.Д. Способы и меры стимулирования инвестиционной активности промышленных предприятий // Актуальные проблемы гуманитарных и естественных наук. $-2011 .-$ C. $117-126$

\section{The text of the article in English}

Formulation of the problem. The recent global economic crisis creates problems that are even more significant and are forcing manufacturing enterprises in the home appliance market to be more creative and ambitious in search of new production and marketing markets. Obviously, the ability of enterprises to identify internal capabilities and distinguish them from competitors is crucial. To maintain their competitive advantage, enterprises must renew their resource base as the environment changes. Innovation plays a decisive role in the future of enterprises, following the fast pace of market evolution and, further, being able to adapt to radical technological changes. It is not surprising that innovation management, based on the results of a marketing analysis of the current state of the household appliance market in the context of innovative economic development, is today one of the most difficult tasks [1].

Various theoretical and practical aspects of the features of scientific research based on marketing analysis are widely represented in the works of foreign and domestic scientists, such as T. Brown, D. Aaker, S. Antholt, T. Gad, M. Dunn, E. Azaryan, V. Anurin, I. Akulich, E. Anokhin, I. Belyaevsky, E. Vanchikova, E. Kuzmina, A. Korotkov, S. Bozhuk.

The main research task is to characterize the innovation policy and determine its role in the competition in the home appliance market, to study in more detail the potential differential impact of the technological innovation potential model on the sustainable competitive advantage in the industry.

The objectives of the study. The purpose of this study is to contribute to theoretical knowledge and study the features of the implementation of marketing analysis as the main stage of marketing research in the home appliance market. Marketing analysis in the home appliance market is an essential point in the work of a marketing manager. A detailed analysis makes it possible to quickly identify unoccupied market niches, choose the most suitable target market, and better understand consumer needs in the home appliance market. The object of research is the household appliance industry, which is the prototype of the high-tech industry. Recently, in connection with the growth of global competition and the global economic crisis, new, more dynamic prospects for strategic management have appeared. The results of marketing analysis are necessary in determining prospects in the field of strategic innovation management in the home appliance market.

Research results and discussion. At the initial stage of marketing analysis in the home appliance market, the objectives of market research should be specified. It is necessary to clarify the following components: company products: analysis of market development and the share of company products 
International Scientific and Practical Conference

ECONOMICS, POLITICS, LAW: TRENDS AND PROSPECTS

in the segment; household appliance market structure: analysis of market conditions and marketing capacity of the market, assessment of market trends; consumer: analysis of demand, basic needs in the market, close marketing study of the behavior and expectations of the target audience; target segment: analysis of the prospects of market segments to select the field of activity; free niches: marketing analysis of market segments to identify free market niches and new sales sources; rivals: analysis of the activities of rivals to identify the competitive superiority of products and the search for weaknesses of the company; prices: a marketing analysis of the price positions of competitors, as well as the current price structure in the industry.

The enlarged stages of the marketing research of the home appliance market are as follows.

1. Market research, its segmentation and identification of the most significant segments.

2. Marketing research of volume, dynamics and market development potential.

3. Price research and general economic analysis of the market.

4. Competitive analysis.

5. The study of advertising methods, ways of promoting and supporting products.

6. Studying the structure of distribution or distribution of goods in the market.

7. Identification of key market and consumer trends.

8. A study of demand, basic needs and nuances of consumer behavior.

Marketing research of the sales market in the household appliance market includes the search for the most effective combination of the used methods and forms of selling goods, their strengths and weaknesses, belonging to a market segment or sales region [1]. The methods of collecting information in the implementation of marketing research can be divided into two groups: qualitative and quantitative. Quantitative market analysis is most often associated with the organization of various surveys. They are based on the application of structured closed-ended questions. Answers are given by a large number of respondents. Qualitative marketing analysis of the market consists of collecting, studying and interpreting information by observing how people behave and what they say. The main stages of the marketing analysis of the household appliance market are presented in Figure 1.

Figure 1 The main stages of the marketing analysis of the household appliance market. (RU Vers.)

At the next stage of studying the features of the marketing analysis of the household appliance market, consider the methods by which this analysis is carried out (table 1). 
International Scientific and Practical Conference

ECONOMICS, POLITICS, LAW: TRENDS AND PROSPECTS

Table 1. Method for conducting a marketing analysis of the household appliance market.

\begin{tabular}{|c|c|l|}
\hline No. & Method Method & \multicolumn{1}{c|}{ properties and specifics } \\
\hline 1 & Focus groups. & $\begin{array}{l}\text { Round table or discussion, where there is a conversation on } \\
\text { a particular topic. Target group of consumers takes part. At } \\
\text { this event, there is a moderator who leads a conversation on a } \\
\text { specific list of issues. This is a qualitative method of marketing } \\
\text { market research, it is useful for understanding the causes of } \\
\text { behavior. Focus groups help formulate hypotheses, explore } \\
\text { the hidden motives of customers. }\end{array}$ \\
\hline 2 & $\begin{array}{l}\text { They imply a survey of the target market on a strict } \\
\text { questionnaire. Largest are both small and large. In a marketing } \\
\text { survey, sampling is of great importance. The larger it is, the } \\
\text { more clear and valid the result will be obtained. This is a } \\
\text { quantitative marketing method. It is used when you need to } \\
\text { get specific indicators on certain issues. }\end{array}$ \\
\hline 3 & Polls. & $\begin{array}{l}\text { Monitoring the behavior of a representative of the target } \\
\text { audience in a normal environment (for example, video in the } \\
\text { store). Refers to quality marketing research methods. }\end{array}$ \\
\hline 4 & $\begin{array}{c}\text { Experiments or field } \\
\text { studies. }\end{array}$ & $\begin{array}{l}\text { Relate to quantitative marketing methods. They make it } \\
\text { possible to test any assumptions and alternatives in real life. }\end{array}$ \\
\hline 5 & depth interviews. & $\begin{array}{l}\text { Conversation with one representative of the target audience on } \\
\text { a specific list of open questions. They provide an opportunity } \\
\text { to thoroughly understand the topic and form hypotheses. } \\
\text { Relate to high-quality marketing methods. }\end{array}$ \\
\hline
\end{tabular}

When conducting an analysis of the home appliance market, one can name a group of analytical and prognostic methods for conducting marketing research, such as: probability theory, linear planning; network planning; methods of business games; economic and mathematical modeling; methods of expert assessment; economic and statistical methods.

Economic growth occurs because people have at their disposal either more resources or better ideas for turning resources into goods and services. An increase in resources alone cannot stimulate sustainable economic growth. Natural resources are limited in a limited world, and although education can significantly increase the productivity of human resources, such achievements are limited by the duration of human life. Indeed, according to estimates by Nobel laureate Robert Solow, less than half of US economic growth is accounted for by an increase in resources. The lion's share of growth is due to technological progress [1]. 
International Scientific and Practical Conference

ECONOMICS, POLITICS, LAW: TRENDS AND PROSPECTS

In addition to the fact that scientific and technical knowledge plays a central role in the steady growth of income levels, they have caused a number of important economic trends. In production, technological progress was the main force underlying the transition from manual to mechanized production methods, from natural to synthetic materials, from humans and animals to mineral energy sources, and from raw labor to highly educated and specialized workers, that is, from technology to innovation. The introduction of innovations often leads to the expansion of markets. Larger markets are needed to allow workers and firms to focus on highly specialized activities and increase the return on innovation associated with investing in specialized knowledge or equipment.

Innovations in the industry have led, accordingly, to sharp changes in the organization of economic activity, the movement of production from home, an increase in the average size of enterprises, concentration of production in cities and an increase in the geographical scale of trade and the role of international transactions in the local and national economies.

Research often generates ideas that are valuable in many areas of the business. Because of this, basic research is supported by public funds, and new discoveries are widely disseminated. In the narrower and more applied fields of knowledge, research is supported through the enforcement of intellectual property rights. They provide inventors with a temporary monopoly on the use of their ideas, allowing them to recoup the costs of research. Intellectual property rights try to balance the desire to reward successful research with the social benefits derived from competitive markets and the widespread dissemination of good ideas. In addition to intellectual property rights, successful public and private research requires an educated workforce. Access to large markets allows firms to allocate fixed costs for inventing a new idea to a large number of product units, increasing the return on research resources. For countries that are not on the technological frontier, technological progress is more driven by imitation than innovation. Many technologies must be adapted to local conditions, including the qualifications of the workforce, the regulatory environment, the availability of vital resources, and cultural differences [2].

Openness to international markets and an effective legal system protecting the rights of foreign investors play an important role in attracting multinational companies using advanced technologies. In many developing countries, including China and India, there has been a notable increase in growth rates immediately after opening access to international trade and foreign investment.

On the other hand, international trade can lead developing countries to specialize in less technologically dynamic economic activities, such as agriculture and mining, and foreign investment in these areas can do little to facilitate the continued transfer of technology [3 ].

Since the introduction of new technology, as a rule, generates both winners and losers, the international transfer of technology may also face deliberate and well-organized opposition, competition. New technologies are often confronted by pre-industrial elites who fear losing leadership in the new industrial class, existing industries that invest in old technologies, and unions that fear losing jobs. 
Although technological progress in the long run raises average incomes, the costs and benefits of new technology tend to be unevenly distributed, which creates a number of problems for countries experiencing rapid technological progress. The introduction of new goods and processes often directly competes with existing economic firms, forcing them to adapt or be squeezed out of business, a process called creative destruction according to economist Joseph Schumpeter [2]. The advent of the personal computer in the 1980s triggered a serious crisis at IBM, a leading manufacturer of mainframes.

The operational model of the impact of innovative capabilities on competitive advantage and business performance stems from the theoretical background and shows our perception of how technological innovative capabilities, competitive advantage and enterprise performance can be interconnected. It is obvious that technological innovative potential rarely arises as a result of the activity of one business entity. Accordingly, technological innovation potential is the result of internal and external sources.

The competition between diversified companies occurs primarily at the level of individual strategic business units. Therefore, technologically innovative capabilities of the company should be analyzed not only at the corporate level, but also at the level of each strategic business unit. From this point of view, the principles of portfolio analysis are used as one of the tools of marketing analysis. The knowledge and skills necessary for each strategic technological unit are evaluated, and then it is necessary to move to the level of the entire enterprise, where general technological knowledge and skills should be determined. Therefore, the innovative and technical potential should be divided into areas of relevant activity and skills, which, as a rule, support the same strategic direction.

Players in the home appliance market of LG, Samsung, Electrolux, Virpul Corporation, Siemens, Walton Group have all the conditions for the development prospects of the home appliance market. Due to the growing demand for energy-efficient products, these industry participants are actively developing devices with a large number of functions, such as, for example, temperature detection. $R \& D$ is also widespread in the household appliance market. Government agencies are implementing various programs, such as a home energy action program, to provide energy-efficient devices to low-income households. In countries focused on minimizing carbon emissions, a number of programs and strategies spur innovation in product development [4].

Home appliance manufacturers invest the most in their R\&D business and focus on efficient product development. For example, modern ovens and other cooking appliances provide advanced touch controls and LCD displays with improved aesthetic values and control functions. In addition, as the Internet of Things (IoT) capabilities expand, it allows you to access devices in real time even without the physical presence of the user. This has led to the easy and efficient use of these products.

Innovation is important at all stages of development; in particular, the creation and diffusion of technology is essential for economic growth and welfare in all countries. Different types of 
innovations play a role at different stages (for example, at earlier stages, incremental innovations are often associated with the introduction of foreign technologies). Opportunities are emerging for successfully conducting innovative experiments and creating a potentially different basis for development. In particular, these opportunities are due to the development of information and communication technologies, the development of global value chains, the increasing role of some developing countries in the global innovation system, the growth of a service-based economy, and greater openness to trade and foreign direct investment. Today, the key objective of innovation policy in developing countries is to stimulate inclusive growth and support research based on marketing analysis aimed at solving basic social problems.

Different types of innovations can play a different role at different stages of development. At earlier stages, gradual innovation is often associated with the introduction of foreign technology, and social innovation can increase the efficiency of business and public services. Innovation based on high technology and $\mathrm{R} \& \mathrm{D}$ is of greater importance at later stages of development and, in most cases, at advanced enterprises in developing countries, when it is a factor of competitiveness and training.

A number of emerging market economies, in particular China, have become important participants in the global innovation system. There is evidence that R\&D played a key role in the rise of Asian economies such as China, India and Korea. Moreover, many emerging market economies have industries or firms that are at the forefront of technology and need innovation to compete.

Innovation can help solve the problem of inequality in developing countries. Although innovation and growth play a central role in solving social problems, improving economic performance and creating jobs, their impact is not necessarily "socially" inclusive, as they can exacerbate income inequality and opportunities for different groups of society. Most of the world's poor live in middleincome countries where income inequality and opportunity inequality are strikingly inconvenient. The reality in many developing countries is that a small portion of the population has access to wider resources and opportunities, while a large group does not have access to basic resources. Many government programs prioritize socially inclusive development, as high levels of inequality can negatively impact growth.

Innovative dynamics and policies influence the "inclusiveness in industry", which is how firms differ in their innovation and productivity. The innovative potential of many developing countries of the economic structure is characterized as the potential of leading enterprises, industries, research institutes or universities that coexist with a group of weakly working enterprises or institutions and a significant informal sector of the economy. Industrial inclusiveness has a potentially important impact on social inclusion. In addition, an important aspect of this inequality is "territorial inclusion" - the geographical aspects of industrial and social inequality [5]. 
A well-thought-out innovation policy based on the results of a marketing analysis of the household appliance market is aimed at using development opportunities taking into account economic and social realities in various regions of the country, whether it be a capital or a remote rural area, by ensuring access of the population and companies to the necessary public goods and services.

Findings. Implementation of the proposed measures in the industrial production industry will significantly increase the level of innovation activity of domestic manufacturing enterprises, stabilize the accelerated process of production renewal, and effectively use internal and external investment for innovative activities.

From the point of view of the importance of the studied objects of research, namely marketing of innovations in production, the effectiveness of its implementation and use in the production environment, it is necessary in further scientific studies to characterize the stages of introducing innovative goods (products) into the manufacturing sector based on the marketing approach and describe the nature of the research work, at the stage of conducting marketing research, which is important when forming a marketing strategy and introducing innovations in production.

\section{References}

1. Nobel Prize in Economics 1987. Robert Solow (1924). Electronic resource. Access mode: http://nobeliat.ru/laureat.php?id=439

2. Federal Statistics Service of the Russian Federation [Electronic resource]. Access Mode: $\underline{\text { https:// }}$ fedstat.ru/organizations/

3. Technological innovation capabilities as a source of competitive advantage: A case study from the home appliance industry. Electronic Resource, Access Mode: https://www.researchgate.net/ publication/268505043_Technological_innovation_capabilities_as_a_source_of_competitive advantage A case study from the home appliance industry

4. Electric Household Appliances Market Size By Product. Electronic resource. Access mode: https://www.gminsights.com/industry-analysis/electric-household-appliances-market

5. Busygin K.D. Methods and measures of stimulating the investment activity of industrial enterprises // Actual problems of the humanities and natural sciences. - 2011. - S. 117-126 
International Scientific and Practical Conference

ECONOMICS, POLITICS, LAW: TRENDS AND PROSPECTS

Contents lists available at ScienceCiteIndex https://sciencecite.scopuseu.com «ECONOMICS, POLITICS, LAW: TRENDS AND PROSPECTS»

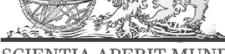
SCIENTIA APERIT MUNN journal homepage: http://scopuseu.com/scopus/index.php/epl/index

O EAP S

УДК 340

\section{Некоторые проблемы правовой регламентации ответственности за преднамеренное банкротство}

Гаврикова Юлия Олеговна

студентка

ФГБОУ ВО «Российский Государственный Университет Правосудия»

(2. Ростов - на - Дону), Россия voronina.voronina1998@yandex.ru

\section{Some problems of legal regulation of liability for intentional bankruptcy}

\section{Gavrikova Julia Olegovna}

student

"Russian State University Of Justice (Rostov-on-Don), Russia

Аннотация: Рассматриваются существующие проблемы ответственности лиц при преднамеренном банкротстве на основе анализа ранее действующего законодательства, норм, существующих в России на сегодняшний день и зарубежного опыта. Предлагается принятие норм, которые бы ужесточили ответственность за преднамеренное банкротство.

Ключевые слова: банкротство; ответственность; преднамеренное банкротство; арбитражный управляющий.

The article examines the existing problems of the responsibility of persons with intentional bankruptcy on the basis of an analysis of the previously existing legislation, the norms that exist in Russia today and foreign experience. It is proposed to adopt rules that would tighten the responsibility for intentional bankruptcy.

Keywords: bankruptcy; liability; intentional bankruptcy; arbitration manager.

(c) 2019 The Author. Published by OEAPS Inc. This is an open access article under the CC BY-NC-ND license (http://creativecommons.org/licenses/by-nc-nd/4.0/) 
До революции 1917 г. в России действовали следующие нормативные акты уголовного характера: Уложение о Наказаниях Уголовных и исправительных 1845 г. (в ред.1866 и 1885 гг.), Устав о наказаниях, налагаемых мировыми судьями 1864 г., Уголовное Уложение 1903 г., (в его статьях введенных в действие, по изданию 1909 г.) [5].

Санкция за банкротство содержалась в Уложении о Наказаниях в статьях 1163-1168, где законодатель разделил банкротство на две категории: злонамеренное (умышленное) и простое (неосторожное).

В данной статье хотелось бы осветить вопросы, связанные с ответственностью за преднамеренное (умышленное) банкротство.

Злонамеренное банкротство тогда понимали, как умышленное сокрытие собственного имущества должником, прекратившим платежи или ставшего несостоятельным, чтобы получить имущественную выгоду и не платить долги кредиторам.

Объектом преступного деяния в данном случае выступает законное право кредиторов на удовлетворение их денежных требований должником, а предметом - имущество, находящееся в собственности недобросовестного должника.

Объективная сторона злонамеренного банкротства выражалась в сокрытии такого имущества. Теория уголовного права, законодатель и судебная практика, сложившаяся на тот момент, приравнивали к сокрытию имущества такие действия, которые фиктивно умаляли имущественную массу должника.

Имущество могло находиться в активе или пассиве. Сокрытие имущества в активе выражалось в том, что должник не оповещал кредиторов об имеющихся у него материальных ценностях или отчуждал их, путем передачи третьим лицам (зачастую - родственникам).

Сокрытие пассивного имущества появлялось, когда выдавали обязательства по долгам, которых не существовало, или они сознательно преувеличивались. Например, выдача бронзовых векселей. Указанные деяния составляли злонамеренное банкротство, как если несостоятельность фактически наступила, так и если предвиделась.

Уложение о Наказаниях выделило в качестве субъектов злонамеренного банкротства лиц, осуществляющих торговлю и всех остальных злостных должников.

Субъективная сторона выражалась умышленными действиями с целью извлечения имущественной выгоды преступником, что несло убытки для кредиторов.

Состав преступления был формальным, поскольку наступление преступных последствий не требовалось, преступление считалось оконченным с момента совершения виновным лицом следующих действий: объявления несостоятельности и имеющегося факта сокрытия имущества. 
International Scientific and Practical Conference ECONOMICS, POLITICS, LAW: TRENDS AND PROSPECTS

Уложение о Наказаниях предусматривало следующие санкции за рассматриваемое преступление: торговцы ссылались в Сибирь на поселение и лишались прав состояния, а лица, не производящие торговлю лишались всех особенных прав и преимуществ и ссылались также в Сибирь или передавались в исправительные арестантские отделения на срок от полутора до двух с половиной лет [8].

Сейчас, вероятность добиться полного удовлетворения своих требований у кредиторов весьма мала. Если имущества не достает для полного погашения обязательств, то требования кредиторов считаются погашенными. В связи с этим возрастает процент использования недобросовестными должниками процедуры банкротства с целью уклонения от погашения кредиторской задолженности, что может признаваться преднамеренным банкротством [9].

Здесь интересы кредиторов защищаются возможностью привлечения к ответственности лиц, совершающих неправомерные действия. Закон «О несостоятельности (банкротстве)» не содержит понятия преднамеренного банкротства, оно закреплено лишь в Кодексе об Административных Правонарушениях и в Уголовном кодексе РФ. Так, законодатель выделяет следующие виды ответственности лиц, виновных в банкротстве должника: административная ответственность (ст.14.12 КоАП РФ); уголовная ответственность (ст. 196 Уголовного кодекса РФ).

Арбитражный управляющий должен выяснить, не является ли банкротство фиктивным или преднамеренным (ст. 20.3 Федерального закона от 26.10.2002 № 127-Ф3) [1].

Порядок такой проверки впервые определили Временные правила проверки арбитражным управляющим наличия признаков фиктивного или преднамеренного банкротства (далее временные правила) [4]. Временными правилами установлен ход проверки. Арбитражный управляющий уполномочен проверить деятельность фирмы не менее чем за последние два года, которые предшествовали банкротству, а также за все время, пока процедура имела место. Он также изучает: бухгалтерскую отчетность, договоры по отчуждению и приобретению имущества, материалы судебных процессов и налоговых проверок должника, перечень его имущества, список дебиторов и др. [7]

Отчет арбитражного управляющего направляется в компетентные органы. Уже полиция решает - целесообразно ли привлечение должника к административной ответственности по основаниям, предусмотренным ст.14.12 КоАП РФ [2]. Если в совершенном деянии содержится признак крупного ущерба, виновное лицо привлекается уже к уголовной ответственности по ст. 196 УК РФ [6]. За преднамеренное банкротство предусмотрены следующие виды наказаний: штраф, принудительные работы, лишение свободы [3].

Уголовное право большинства государств содержит ответственность за незаконное банкротство. Важным международным актом в рассматриваемой сфере является Конвенция, принятая государствами-участниками Совета Европы «О некоторых международных аспектах 102 
банкротства», а также Типовой закон ЮНСИТРАЛ «О трансграничной несостоятельности» 1997 г.

Интересным представляется тот факт, что в уголовном праве многих зарубежных стран, присутствует четкое разграничение терминов «несостоятельность» и «банкротство». Считается, что «несостоятельность» не содержит в себе умысла, а «банкротство», предполагает уголовно-правовой характер дела. В США регламентация института несостоятельности относится к ведению Конгресса, хотя некоторые вопросы каждый штат вправе решать самостоятельно. Ответственность за незаконное банкротство отражается в Примерном Уголовном кодексе США, где преднамеренное банкротство признается преступлением.

Так, статья 224.10 «Обман кредиторов по обеспеченному долгу» предусматривает ответственность за непосредственный обман в случаях неплатежеспособности, например, за уничтожение, изъятие, сокрытие, обременение обязательствами или передачу имущества, в отношении которого имеется залоговый интерес, и т. д.

За подобные преступления Примерный УК США не устанавливает жестких мер пресечения (до одного года тюремного заключения). В штатах же установлены более жесткие санкции. Практики говорят, что возрастает количество тяжких банкротств, и ущерб интересов кредиторов не мал. Статистика судебных дел в США гласит, что из всех дел, которые рассмотрены судами по банкротству, только по $1,1 \%$ из них виновные в умышленном банкротстве были привлечены к ответственности. К факторам, лежащим в основе банкротства, относятся: небрежность - $2 \%$, злоупотребления $-1,5 \%$, бедствия $-0,9 \%$, некомпетентность специалистов - 93, 1 \%, прочие - 2,5 \% [10].

Законодательство Германии наряду с нормами о банкротстве общего характера предусматривает специальные нормы ответственности за благоприятствование одному из кредиторов в ущерб другим, за отсутствие бухгалтерских книг, а также совершение неправомерных действий в пользу недобросовестного должника. Да, в УК РФ есть похожая норма о неправомерном удовлетворении требований кредиторов, но нормы за отсутствие бухгалтерского баланса не предусмотрено. Считаем, что это является пробелом правового регулирования ответственности за преднамеренное банкротство в нашей стране.

В гражданском законодательстве России также предусмотрена обязанность руководителя обратиться в арбитражный суд при установлении признаков банкротства, но за уклонение от исполнения таких требований, как в Германии, УК РФ не содержит.

Так, можно с уверенностью говорить, что зарубежный опыт в сфере уголовно-правового регулирования банкротства должен представлять интерес для отечественного законодателя. Многие нормы имеют место быть в нашей правовой системе с учетом некоторых особенностей российского законодательства. Не секрет, что стабильность экономики, гарантированность 
International Scientific and Practical Conference

ECONOMICS, POLITICS, LAW: TRENDS AND PROSPECTS

защиты законных имущественных интересов кредиторов от недобросовестных действий со стороны должников определяется в немалой степени регламентацией более полной уголовной ответственности за преднамеренное банкротство.

Сложившаяся на сегодня в России экономическая ситуация, на наш взгляд, требует изменения законодательства в части ужесточения ответственности за незаконное банкротство, в частности: введения норм, устанавливающих уголовную ответственность арбитражного управляющего за сокрытие от компетентных органов информации о преднамеренном банкротстве должника, ставшей известной ему в ходе проведения проверки, а также за уклонение от обращения в Арбитражный Суд руководителя должника с инициативой начала дела о банкротстве, если есть все основания предполагать, что имеется угроза банкротства; ввести административную ответственность, если не имеется регистрации актов и фактов, имеющих значение для конкурсного производства, за ложные заявления и невыполнение требований к отчетам в конкурсном производстве; нарушения ограниченной правоспособности и др.

\section{Список литературы}

1. О несостоятельности (банкротстве): Федеральный закон от 26 октября 2002 г. № 127-Ф3. 2. Кодекс Российской Федерации об административных правонарушениях от 30.12.2001 N 195-ФЗ//СПС «КонсультантПлюс».-Режим доступа :http://www.consultant.ru- сайт компании «КонсультантПлюс».

3. Уголовный кодекс Российской Федерации от 13 июня 1996 г. №63-Ф3 // Собрание законодательства Российской Федерации. 1996. №25. Ст. 2954.

4. Временные правила проверки арбитражным управляющим наличия признаков фиктивного и преднамеренного банкротства (утв. постановлением Правительства Рос. Федерации от 27 декабря 2004 г. № 855.

5. Российское законодательство X-XX веков: в 9 т. Т. 1. Законодательство Древней Руси. М.: 1994.

6. Жадан В. Н. К вопросу о доказывании фактов преднамеренного банкротства предприятий // Молодой ученый. 2013. №3. С. 351-355.

7. Коршунов А. Проверка банкротов на честность. «Ваш партнер - консультант» 2005.

8. Шершеневич Г. Ф. Курс торгового права: в 4 т. Т. 4. Торговый процесс. Конкурсный процесс. М., 2016.

9. Экономика и управление на предприятиях: научно-образовательный портал. URL: www. eup.ru.

10. Время и деньги. Сайт Юрия Алаева. URL: https://www.e-vid.ru/en/node/3057. 


\section{The text of the article in English}

Before the revolution of 1917 The following criminal acts were in force in Russia: the Code on Punishments of Criminal and Correctional Laws of 1845 (as amended by 1866 and 1885), the Charter of the punishments imposed by magistrates in 1864, and the Corner . vnoe Code of 1903 (in his articles brought into use, for the publication of 1909) [5]

The sanction for bankruptcy contained in the Penal Code in articles 1163-1168, where the legislator has divided the bankruptcy of two categories: malicious (intentional) and simple (careless).

This article would like to highlight issues related to liability for intentional (intentional) bankruptcy. Malicious bankruptcy was then understood as the deliberate concealment of one's own property by a debtor who ceased payments or became insolvent in order to obtain property benefits and not pay debts to creditors.

In this case, the object of a criminal act is the legal right of creditors to satisfy their monetary claims by the debtor, and the subject is property owned by an unscrupulous debtor.

The objective side of malicious bankruptcy was the concealment of such property. The theory of criminal law, the legislator and judicial practice prevailing at that time equated such actions with fake concealment of property that fictitiously diminished the property mass of the debtor.

The property could be in an asset or liability. The concealment of property in an asset was expressed in the fact that the debtor did not notify creditors of the material assets he had or alienated them by transferring them to third parties (often to relatives).

Concealment of passive property appeared when issuing obligations for debts that did not exist, or they were deliberately exaggerated. For example, the issuance of bronze bills. These acts constituted malicious bankruptcy, as if the insolvency actually occurred, and if anticipated.

The Punishment Code singled out as the subjects of malicious bankruptcy of persons engaged in trade and all other malicious debtors.

The subjective side was expressed by deliberate actions with the aim of extracting property benefits by the criminal, which incurred losses for creditors.

The composition of the crime was formal, since the onset of criminal consequences was not required, the crime was considered completed from the moment the perpetrator committed the following actions: declaration of insolvency and the fact of concealing property.

The Punishment Code provided for the following sanctions for the crime in question: merchants referred to Siberia for settlement and were deprived of their rights, and non-traders were deprived of all special rights and advantages and were also referred to Siberia or transferred to correctional detention centers for a term of one and a half to two and a half years [8]. 
International Scientific and Practical Conference

ECONOMICS, POLITICS, LAW: TRENDS AND PROSPECTS

Now, the likelihood of complete satisfaction of their claims by lenders is very small. If the property is not enough to fully repay the obligations, then the claims of the creditors are deemed repaid. In this regard, the percentage of use by dishonest debtors of the bankruptcy procedure is increasing in order to evade repayment of payables, which may be considered intentional bankruptcy [9].

Here, the interests of creditors are protected by the possibility of bringing to justice those who commit unlawful acts. The Law on Insolvency (Bankruptcy) does not contain the concept of intentional bankruptcy; it is enshrined only in the Code of Administrative Offenses and in the Criminal Code of the Russian Federation. So, the legislator identifies the following types of liability of persons guilty of bankruptcy of the debtor: administrative responsibility (Article 14.12 of the Administrative Code of the Russian Federation); criminal liability (Article 196 of the Criminal Code of the Russian Federation).

The arbitration manager must determine whether the bankruptcy is fictitious or deliberate (Article 20.3 of the Federal Law of October 26, 2002 No. 127-Ф3) [1].

The procedure for such verification was first determined by the Interim Rules for the verification by the arbitration manager of the presence of signs of fictitious or intentional bankruptcy (hereinafter - the provisional rules) [4]. Temporary rules set the course of verification. The arbitration manager is authorized to check the activities of the company for at least the last two years that preceded bankruptcy, as well as for the entire time that the procedure took place. He also studies: accounting reports, agreements on the alienation and acquisition of property, materials of litigations and tax audits of the debtor, a list of his property, a list of debtors, etc. [7] The

report of the arbitration manager is sent to the competent authorities. The police already decide whether it is advisable to bring the debtor to administrative responsibility on the grounds provided for in Article 14.12 of the Administrative Code of the Russian Federation [2]. If the committed act contains a sign of major damage, the guilty person is already held criminally liable under Art. 196 of the Criminal Code [6]. The following types of punishments are provided for deliberate bankruptcy: fine, forced labor, imprisonment [3].

The criminal law of most states contains liability for unlawful bankruptcy. An important international act in this area is the Convention adopted by the Council of Europe member states "On some international aspects of bankruptcy", as well as the UNCITRAL Model Law "On Cross-Border Insolvency" of 1997.

It is interesting to note that the criminal law of many foreign countries contains a clear distinction between the terms "insolvency" and "bankruptcy". It is believed that "insolvency" does not contain intent, but "bankruptcy" implies the criminal nature of the case. In the United States, insolvency regulation is the responsibility of Congress, although each state is free to resolve certain issues on its own. Liability for unlawful bankruptcy is reflected in the United States Model Penal Code, where intentional bankruptcy is a criminal offense. 
So, article 224.10 "Deception of creditors on secured debt" provides for liability for direct fraud in cases of insolvency, for example, for the destruction, seizure, concealment, encumbrance of obligations or transfer of property with respect to which there is a mortgage interest, etc.

For such crimes The approximate US Criminal Code does not establish harsh preventive measures (up to one year in prison). The states have set more stringent sanctions. Practitioners say that the number of serious bankruptcies is increasing, and the damage to the interests of creditors is not small. US court statistics say that out of all the cases that have been tried by the bankruptcy courts, only $1.1 \%$ of those responsible for intentional bankruptcy were held accountable. The factors underlying bankruptcy include: negligence - $2 \%$, abuse - $1.5 \%$, disasters $-0.9 \%$, incompetence of specialists - $93,1 \%$, others $-2.5 \%[10]$.

German law, along with general bankruptcy rules, provides for special liability rules for favoring one of the creditors to the detriment of others, for the lack of books, as well as for committing unlawful actions in favor of an unscrupulous debtor. Yes, there is a similar rule in the Criminal Code of the Russian Federation on the unlawful satisfaction of creditors' claims, but there is no provision for a lack of balance sheet. We believe that this is a gap in the legal regulation of liability for intentional bankruptcy in our country.

The civil legislation of Russia also provides for the obligation of the head to appeal to the arbitration court when signs of bankruptcy are established, but does not contain the Criminal Code of the Russian Federation for evading the execution of such requirements as in Germany.

So, we can confidently say that foreign experience in the field of criminal regulation of bankruptcy should be of interest to the domestic legislator. Many norms have a place to be in our legal system, taking into account some features of Russian legislation. It is no secret that the stability of the economy, the guarantee of protection of the legitimate property interests of creditors from dishonest actions on the part of debtors, is determined to a large extent by the regulation of more complete criminal liability for intentional bankruptcy.

The current economic situation in Russia, in our opinion, requires legislative changes to toughen liability for unlawful bankruptcy, in particular: introducing rules establishing the criminal liability of an arbitration manager for concealing from the competent authorities information about the deliberate bankruptcy of a debtor that became known to him during conducting an audit, as well as for avoiding appeal to the Arbitration Court of the head of the debtor with the initiative to initiate bankruptcy proceedings, if everything is based Ia to assume that there is a threat of bankruptcy; introduce administrative responsibility if there is no registration of acts and facts of relevance to bankruptcy proceedings for false statements and failure to comply with reporting requirements in bankruptcy proceedings; violations of limited legal capacity, etc. 


\section{References}

1. On insolvency (bankruptcy): Federal Law of October 26, 2002 No. 127-Ф3.

2. The Code of the Russian Federation on administrative offenses dated 30.12.2001 N 195-Ф3// ATP "Consultant Plus." - Access mode: http: //www.consultant.ru - site of the company "Consultant Plus".

3. The Criminal Code of the Russian Federation of June 13, 1996 No. 63-FZ // Collection of legislation of the Russian Federation. 1996. No. 25. Art. 2954.

4. Temporary rules for checking by an arbitration manager for signs of fictitious and deliberate bankruptcy (approved by Decree of the Government of the Russian Federation of December 27, 2004 No. 855.

5. Russian legislation of the 10th - 20th centuries: 9 vol. T. 1. Legislation Ancient Russia. M: 1994. 6. Zhadan V. N. On the issue of proving the facts of intentional bankruptcy of enterprises // Young Scientist. 2013. No. 3. P. 351-355.

7. Korshunov A. Verification of bankruptcy for honesty. "Your partner is a consultant "2005.

8. G. Shershenevich F. Commercial law course: 4 vol. T. 4. Trading process. Conc ursny process M., 2016.enterprises:

9. Economics and Management of scientific and educational portal URL:. www.eup.ruURL:... 10. Time and Money Website Yuri Alaeva https: //www.e-vid .ru / en / node / 3057. 


\section{Contents lists available at ScienceCite}

International Scientific and Practical Conference

«ECONOMICS, POLITICS, LAW: TRENDS AND PROSPECTS», September (2019)

journal homepage: http://scopuseu.com/scopus/index.php/epl/index 
MINISTERIO DE EDUCACIÓN, CULTURA Y DEPORTE

Subsecretaría

Subdirección General de Cooperación Internacional

Edita: @ SECRETARÍA GENERAL TÉCNICA

Subdirección General de Documentación y Publicaciones

Edición: 2019

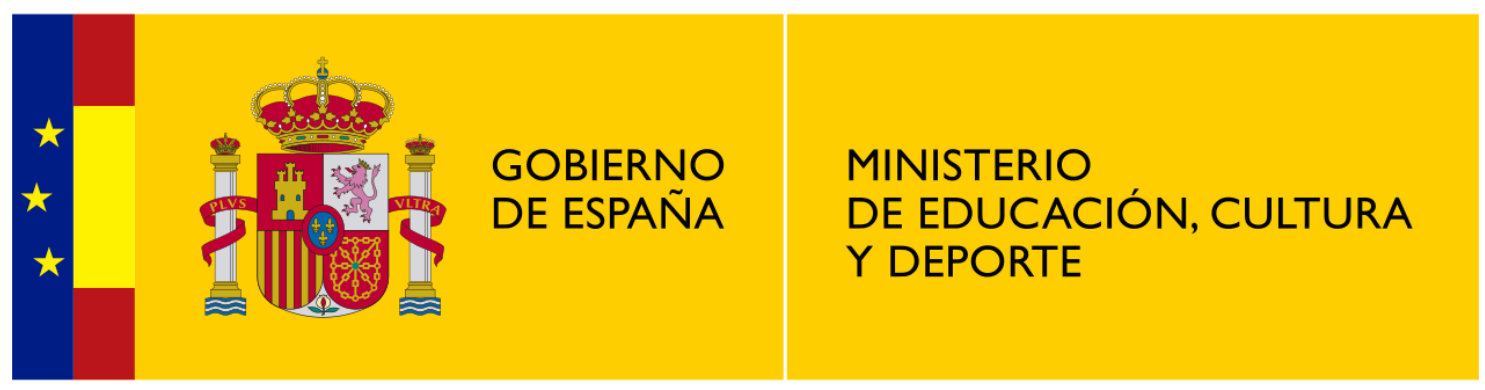

Approved at the meeting of the editorial board International Scientific and Practical Conference ECONOMICS, POLITICS, LAW: TRENDS AND PROSPECTS ICEPL September 2019: сб.науч.тр./ RELF Group \& OEAPS Inc.; редкол.: Флора Бертран (отв.ред.) [и др.]. Берлин, Германия : OEAPS Inc., 05. 2019. - 110 C.

Number layout 20.09.2019

Signed in print 25.09.2019

Published on 26.09.2019 



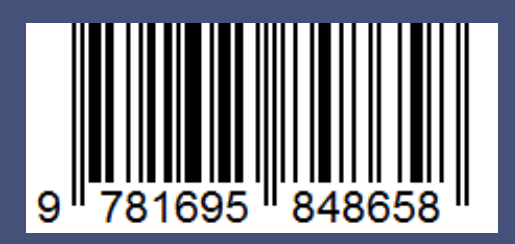

